3-1-2004

\title{
Adrift on a Sea of Uncertainty: Preserving Uniformity in Patent Law Post-Vornado Through Deference to the Federal Circuit
}

\author{
Larry D. Thompson \\ University of Georgia School of Law, Ithomps@uga.edu
}

p bSRN

\section{Repository Citation}

Larry D. Thompson, Adrift on a Sea of Uncertainty: Preserving Uniformity in Patent Law Post-Vornado Through Deference to the Federal Circuit (2004),

Available at: https://digitalcommons.law.uga.edu/fac_artchop/649

This Article is brought to you for free and open access by the Faculty Scholarship at Digital Commons @ University of Georgia School of Law. It has been accepted for inclusion in Scholarly Works by an authorized administrator of Digital Commons @ University of Georgia School of Law. Please share how you have benefited from this access For more information, please contact tstriepe@uga.edu. 


\section{Adrift on a Sea of Uncertainty: Preserving Uniformity in Patent Law Post-Vornado Through Deference to the Federal Circuit}

LARRY D. THOMPSON, JR.*

\section{TABLE OF CONTENTS}

INTRODUCTION $\ldots \ldots \ldots \ldots \ldots \ldots \ldots \ldots \ldots \ldots \ldots \ldots \ldots \ldots \ldots \ldots \ldots \ldots$

I. Vornado and the Triumph of the Plaintiff as "Master of the Claim" over Patent-Law Uniformity . . . . . . . . . .

A. THE (SHORT) STORY OF THE FEDERAL CIRCUIT $\ldots \ldots \ldots \ldots$

B. THE SCOPE OF THE FEDERAL CIRCUIT'S PRE-VORNADO PATENT JURISDICTION $\ldots \ldots \ldots \ldots \ldots \ldots \ldots \ldots$

1. Relevant Jurisdictional Statutes and Early Jurisdictional Issues $\ldots \ldots \ldots \ldots \ldots \ldots \ldots \ldots \ldots \ldots \ldots \ldots \ldots \ldots \ldots$

2. Christianson: The Supreme Court Addresses Jurisdiction over Patent Issues . . . . . . . . . . . . . .

3. Post-Christianson Cases Dealing with Jurisdiction over Patent Counterclaims ..................

C. VORNADO: A NEW JURISDICTIONAL RULE FOR PATENT COUNTERCLAIMS $\ldots \ldots \ldots \ldots \ldots \ldots \ldots \ldots \ldots \ldots \ldots \ldots \ldots \ldots \ldots$

1. Procedural History . . . . . . . . . . . . . . . 540

2. Majority Opinion . . . . . . . . . . . . . . . 542

3. Concurring Opinions . . . . . . . . . . . . . 544

D. ANALYSIS OF VORNADO: DID CONGRESS INTEND FOR PATENT-INFRINGEMENT COUNTERCLAIMS TO "ARISE UNDER" PATENT LAW? . . . . . . . . . . . . . . . .

1. How Did Congress Intend the Federal Circuit's Patent Jurisdiction to Be Determined? . . . . . . . . . . . .

* Law Clerk to the Hon. J. Michael Luttig, Circuit Judge, U.S. Court of Appeals for the Fourth Circuit, 2003-04. J.D., New York University, 2003; B.S.Ch.E., Rice University, 1998. Registered to practice before the U.S. Patent and Trademark Office, 1999. I would like to thank the following people for their contributions to this Article: Professor Barry Friedman for his guidance and encouragement; Judge Harry T. Edwards for his helpful feedback on an early outline; Dean Munyon and Kanika Provost for their comments and advice; and finally, my family for all their love and support. 
2. Did Congress Expect Patent Counterclaims to Create

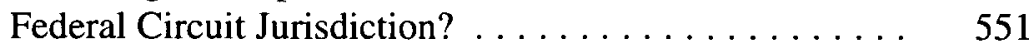

3. Vornado and Congressional Intent ............ 554

4. Problems with Justice Ginsburg's Proposed Rule . . . . . 560

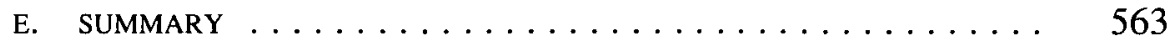

II. Problems if Current Choice-of-Law Rules Are Applied . . . . . 563

A. CURRENT RULE OF NO DEFERENCE TO A COORDINATE FEDERAL

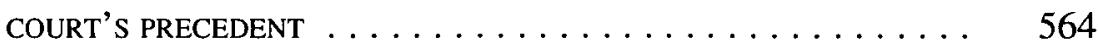

B. PROBLEMS IF THE RULE OF NO DEFERENCE IS FOLLOWED $\ldots \ldots \ldots 568$

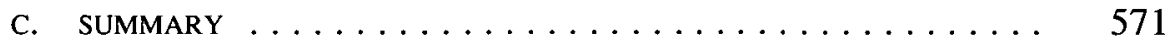

III. Preserving Uniformity in Patent Law Through Deference to

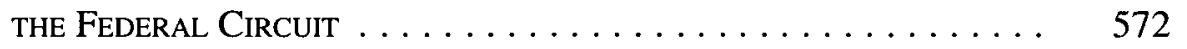

A. A NEW PARADIGM: WHY THE RULE OF NO DEFERENCE SHOULD NOT

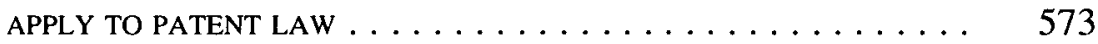

1. Congress Intended the Federal Circuit to Have Special Competence in Patent Law .................

2. Congress Rejected Percolation Benefits in Creating the

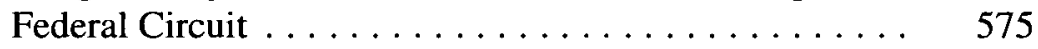

B. UNIFORMITY, CONGRESSIONAL INTENT, AND PATENT LAW . . . . 578

C. COMPARISON TO OTHER CHOICE-OF-LAW EXCEPTIONS $\ldots \ldots \ldots .580$

1. Deference of the Federal Circuit to RCCOAs on Nonpatent Issues $\ldots \ldots \ldots \ldots \ldots \ldots \ldots \ldots$

2. Deference to the "Home Circuit" on Open Issues of State Law . . . . . . . . . . . . . . . . . . . . . . 584

3. Deference to a Predecessor Court $\ldots \ldots \ldots \ldots \ldots \ldots \quad 588$

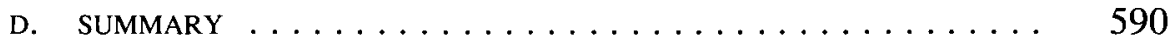

IV. Determining the Appropriate Scope and Level of Deference to the Federal Circuit $\ldots \ldots \ldots \ldots \ldots \ldots \ldots \ldots \ldots \ldots \ldots \ldots \ldots$

A. DETERMINING THE APPROPRIATE SCOPE OF DEFERENCE $\ldots \ldots \ldots \quad 591$

1. What Claims? . . . . . . . . . . . . . . 591

2. What Issues? . . . . . . . . . . . . . . . 592

B. DETERMINING THE APPROPRIATE LEVEL OF DEFERENCE $\ldots \ldots \ldots \quad 593$ 
1. A Choice: Conditional or Unconditional Deference ....

2. Dealing with Open Questions $\ldots \ldots \ldots \ldots \ldots \ldots$

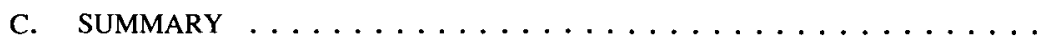

V. Avoiding the False Choice: Deference as a Long-Term SOlution AND OTHER IsSUes $\ldots \ldots \ldots \ldots \ldots \ldots \ldots \ldots$

A. PRESERVING UNIFORMITY IN PATENT LAW AND THE PLAINTIFF'S CHOICE OF APPELLATE FORUM THROUGH DEFERENCE TO THE FEDERAL CIRCUIT $\ldots \ldots \ldots \ldots \ldots \ldots \ldots \ldots \ldots$

B. METHODS OF IMPLEMENTATION $\ldots \ldots \ldots \ldots \ldots \ldots \ldots \ldots 60 \ldots$

1. Congressional Enactment . . . . . . . . . . . 605

2. Voluntary Adoption by Federal Courts . . . . . . . 605

3. A Combination of Methods . . . . . . . . . . . 606

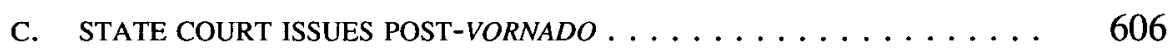

D. $\quad$ SUMMARY $\ldots \ldots \ldots \ldots \ldots \ldots \ldots \ldots \ldots \ldots \ldots \ldots \ldots \ldots \ldots$

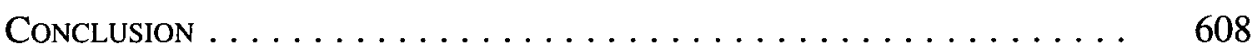

\section{INTRODUCTION}

Congress created the United States Court of Appeals for the Federal Circuit in 1982. In doing so, Congress granted that court exclusive, nationwide jurisdiction over all appeals from final decisions of federal district courts in cases where the jurisdiction of the district court was based, "in whole or in part," on "any civil action arising under any Act of Congress relating to patents." congressional goal in centralizing appeals from patent cases in a single appellate court was to ensure a more uniform patent jurisprudence, thereby producing a more consistent resolution of patent disputes and reducing forum shopping based on favorable patent law. ${ }^{3}$ In the eyes of many commentators, the Federal Circuit has done an admirable job achieving those goals. ${ }^{4}$

Relatively early in its existence, the Federal Circuit recognized that its

1. 28 U.S.C. $\S 1295(a)(1)(2000)$ ("[T]he Federal Circuit shall have exclusive jurisdiction ... of an appeal from a final decision of a district court of the United States . . if the jurisdiction of that court was based, in whole or in part, on section 1338 of this title ...").

2. 28 U.S.C. $\$ 1338(a)(2000)$ ("The district courts shall have original jurisdiction of any civil action arising under any Act of Congress relating to patents... . Such jurisdiction shall be exclusive of the courts of the states ....").

3. See, e.g., H.R. REP. No. 97-312, at 20 (1981) (The Federal Circuit "will provide nationwide uniformity in patent law" and "make the rules applied in patent litigation more predictable"; such uniformity will "eliminate the expensive, time-consuming and unseemly forum-shopping that characterizes litigation in the field.').

4. See, e.g., infra notes $42-43$ and accompanying text. 
exclusive appellate jurisdiction did not include cases containing only a patent issue, but not any patent claim-for example, those cases in which a patent defense was raised to a nonpatent claim..$^{5}$ In attempting to fulfill the congressional goals for which it was created, however, the Federal Circuit interpreted its exclusive jurisdiction to include cases where the complaint did not allege a patent claim, but the answer contained a patent counterclaim. ${ }^{6}$ For over a decade this was considered established doctrine: The Federal Circuit asserted jurisdiction over an appeal regardless of whether patent claims had been raised in the complaint or in the answer (at least for compulsory patent counterclaims), and applied its own law to patent issues present in these cases. ${ }^{7}$

This changed abruptly in 2002. That year, the Supreme Court decided Holmes Group, Inc. v. Vornado Air Circulation Systems, Inc. ${ }^{8}$ in which the Court concluded that in determining whether a patent-infringement counterclaim "arises under" federal patent law, the well-pleaded complaint rule defined the Federal Circuit's jurisdiction to the same extent that it did with general federal-question jurisdiction. The Vornado Court thus held that the Federal Circuit could not assert jurisdiction over an appeal based solely on a compulsory patent counterclaim raised in the answer. ${ }^{9}$

Vornado opens the door for the Regional Circuit Courts of Appeals (RCCOAs) for example, the United States Court of Appeals for the Second Circuit-to hear appeals of cases where patent claims are presented only as counterclaims, while leaving unanswered the question of what law will govern these claims. Generally, however, federal courts of appeals follow what can be called the "rule of no deference," which allows courts to treat the decisions of coordinate federal courts as persuasive, but prohibits deference to them. ${ }^{10}$ Application of this rule here would free RCCOAs to independently develop patent caselaw in appeals where patent claims are presented only as counterclaims.

This situation has several detrimental consequences. As a practical matter, the RCCOAs are inexperienced in deciding patent appeals, not having done so on a regular basis since the Federal Circuit's creation more than twenty years ago. In addition, confusion may ensue in federal district courts as to whether the old RCCOA patent precedents or the newer Federal Circuit ones should govern a

5. See, e.g., Christianson v. Colt Indus. Operating Corp., 822 F.2d 1544, 1551 (Fed. Cir. 1987) (noting "the absurdity of supposing that Congress intended our jurisdiction ... to turn on whether a patent question is raised in an argument against or defense on cross-motions for summary judgment in an antitrust suit").

6. See Aerojet-General Corp. v. Machine Tool Works, Oerlikon-Buehrle Ltd., 895 F.2d 736, 737 (Fed. Cir. 1990) (as to compulsory counterclaims); DSC Commun. Corp. v. Pulse Commun., Inc., 170 F.3d 1354, 1359 (Fed. Cir. 1999) (as to permissive counterclaims).

7. See, e.g., Cases and Recent Developments, 12 FED. CIR. B.J. 135, 195 (2002) (noting that most patent litigants "have long taken for granted that all appeals in cases with patent claims, whether by the plaintiff or original defendant, are heard by the Federal Circuit").

8. 535 U.S. 826 (2002).

9. See id. at 832 .

10. See infra note 216 and accompanying text. 
particular issue. But more important, by both threatening the uniformity in patent jurisprudence produced by the Federal Circuit and facilitating patentbased forum shopping, the application of the rule of no deference in this context potentially reintroduces the very problems that the Federal Circuit was created to resolve. To borrow the words that the Federal Circuit used when departing from the rule of no deference to avoid an analogous situation, blind adherence to that rule here would set the patent-litigating public "adrift on a sea of uncertainty." "11

The serious problems Vornado creates in this regard have been recognized by several commentators. ${ }^{12}$ But many proposals to resolve these problems appear predicated on assumptions similar to the one made by no less eminent a jurist than John Paul Stevens: that, post-Vornado, other courts will of necessity independently develop patent case law when they adjudicate patent counterclaims. ${ }^{13}$ As such, industry groups and commentators have focused their attention on approaches that attempt to preserve uniformity and prevent patent-based forum shopping by expanding the jurisdiction of the Federal Circuit to include some or all patent counterclaims. ${ }^{14}$ No one yet has provided a detailed analysis of the merits and feasibility of deference to the Federal Circuit as a means of addressing the problems created by Vornado. ${ }^{15}$

This Article demonstrates that deference to the Federal Circuit on patent issues produced by patent counterclaims not only is possible, but is the best way to address these problems. First, close analysis reveals that the traditional justifications for the rule of no deference are inapplicable in this context. Second, by preserving uniformity in patent law and reducing motivation for patent-based forum shopping, deference to the Federal Circuit would further the clear congressional goals for which the Federal Circuit was created. Third, such deference is also supported under choice-of-law principles by analogy to other areas where federal courts of appeal have departed from the general rule of no

11. S. Corp. v. United States, 690 F.2d 1368, 1371 (Fed. Cir. 1982) (en banc).

12. See, e.g., Molly Mosley-Goren, Jurisdictional Gerrymandering? Responding to Holmes Group v. Vornado Air Circulation Systems, 36 J. Marshall L. Rev. 1, 3 n.12, 36 (2002) (collecting sources that discuss "how the uniformity of patent law will erode" post-Vornado, and noting that "[r]egional circuits deciding patent law claims found in counterclaims and other claims for relief outside the complaint will erode patent law uniformity"); Edward G. Poplawski, Patent Litigation After Vornado, 725 PLI/PAT 407, 421 (2002) (concluding that the "Vornado decision expands the opportunities for forum and claim shopping").

13. Vornado, 535 U.S. at 839 (Stevens, J., concurring in part and concurring in the judgment) ("Necessarily, therefore, other circuits will have some role to play in the development of this area of the law.").

14. See Mosley-Goren, supra note 12, at 29-30 (discussing proposals to alter the jurisdictional statutes for the Federal Circuit).

15. But some commentators have mentioned in passing the possibility of deference to the Federal Circuit, often acknowledging the potential limitation of the rule of no deference (though not in so many words) as a bar. See, e.g., Christian A. Fox, Note, On Your Mark, Get Set, Go! A New Race to the Courthouse Sponsored by Holmes Group, Inc. v. Vornado Air Circulation Systems, Inc., 2003 BYU L. REv. 331, 348 n. 102. 
deference and, instead, voluntarily deferred to the precedents of other federal appellate courts. Of particular interest is the Federal Circuit's policy to defer conclusively on nonpatent issues to the decisional law of the RCCOA for the circuit from which a case originated.

Furthermore, this Article explains that regardless of the merits of jurisdictional modifications as a long-term solution to these problems, until such modifications are enacted, these problems will continue to exist. Deference to the Federal Circuit is, at minimum, an appropriate way to address these problems in the short-term. In particular, the level of deference that this Article recommends should be given to the Federal Circuit's patent precedentsconditional deference by RCCOAs and unconditional deference by district courts-could prevent almost all of the damage to the goal of uniformity in patent law potentially caused by Vornado, while still allowing some room for independent development of patent law by RCCOAs where justified. And when implemented as a long-term solution, the deference recommended by this Article could achieve all of those goals, while serving other interests that jurisdictional modifications would frustrate; in particular, such deference would uphold the policies behind the well-pleaded complaint rule and retain the plaintiff's traditional prerogative as "the master of the claim."16

Part I of the Article provides an overview of the history of the Federal Circuit and the cases defining the scope of its patent jurisdiction pre-Vornado. It examines the relevant legislative history to determine congressional intent as to the Federal Circuit's patent jurisdiction, and then analyzes the Vornado decision in that context. Part II discusses the rule of no deference and the traditional policies used to justify it. It then explains the problems that will result from adherence to the rule post-Vornado. Part III explains that, no matter what approach Congress adopts as a long-term solution to the problems created by Vornado, deference to the Federal Circuit is appropriate in the short-term. In doing so, it first demonstrates how the traditional justifications for the rule of no deference are inapplicable in this context. Then, it explains how deference serves congressional intent-both as broadly stated and as specifically related to patent counterclaims - and compares favorably with other exceptions to the rule of no deference. Part IV delves into the question of the appropriate scope and level of deference to the Federal Circuit. In particular, it discusses the specific types of issues for which deference to the Federal Circuit's patent precedents should be given. It also looks at whether conditional or unconditional deference is more appropriate, as well as how courts should handle open patent issues. Part V explains the superiority of deference to the Federal Circuit over jurisdictional modifications as a long-term solution. It also analyzes the options for implementing such deference, and concludes by briefly investigating the prob-

16. Cf. Caterpillar Inc. v. Williams, 482 U.S. 386, 392 (1987) (explaining how the well-pleaded complaint rule "makes the plaintiff the master of the claim," one who may avoid having her claim adjudicated in any federal court "by exclusive[ly] rel[ying] on state law" in crafting her allegations). 
lems that Vornado creates in the state courts and suggesting how those analogous problems might be addressed.

\section{Vornado and the Triumph of the Plaintiff as "Master of THE Claim" over Patent-Law Uniformity}

Before examining the problems created by Vornado, it is useful to investigate the background against which the decision arose. This Part provides such a background. First, Part I.A offers a relatively brief history of the Federal Circuit: when it was created, for what purposes, and to what extent it has achieved the goals set for it. After that, Part I.B examines the scope of the Federal Circuit's patent jurisdiction pre-Vornado. Part I.C then breaks down the Vornado decision itself. Finally, Part I.D examines the legislative history to determine how Congress intended the Federal Circuit's patent jurisdiction to be determined generally, as well as whether Congress intended patent counterclaims to create Federal Circuit jurisdiction. It then examines the extent to which both the majority and the separate opinions in Vornado, as well as decisions in related cases, comport with that evidence of congressional intent.

\section{A. THE (SHORT) STORY OF THE FEDERAL CIRCUIT}

The Federal Circuit was established as an Article III court of appeals just over twenty years ago by the Federal Courts Improvement Act of 1982 (FCIA). ${ }^{17}$ The court was formed by combining the appellate jurisdiction of the Court of Claims and the full jurisdiction of the Court of Customs and Patent Appeals (CCPA); the trial jurisdiction of the Court of Claims was given to the new Claims Court, an Article I court later renamed the United States Court of Federal Claims. ${ }^{18}$ In creating these two courts, Congress sought to "fill a void in the judicial system by creating an appellate forum capable of exercising nationwide jurisdiction over appeals in areas of the law where Congress determines there is a special need for nationwide uniformity" as well as "to provide an upgraded and better organized trial forum for government claims cases."19 Consistent with this goal, the Federal Circuit was given jurisdiction over essentially all the jurisdictional subjects of its predecessors, ${ }^{20}$ as well as several

17. Federal Courts Improvement Act, Pub. L. No. 97-164, 96 Stat. 25 (1982) (codified as amended in scattered sections of U.S.C. tit. 28).

18. See Joseph R. Re, Brief Overview of the Jurisdiction of the U.S. Court of Appeals for the Federal Circuit Under $\S 1295(a)(I), 11$ FED. CIR. B.J. 651, 651 \& n.4 (2002).

19. S. ReP. No. 97-275, at 2 (1981), reprinted in 1982 U.S.C.C.A.N. 11, 12; see also United States v. Hohri, 482 U.S. 64, 71-72 (1987), cited in Re, supra note 18, at 651. Congress identified these uniformity concerns as manifesting themselves in two situations: those in which "appellate courts reach inconsistent decisions on the same issue, or in which-although the rule of law may be fairly clear-courts apply the law unevenly when faced with the facts of individual cases." S. REP. No. 97-275, at 3, 1982 U.S.C.C.A.N. at 13.

20. See Re, supra note 18, at 653-55 (citations omitted). 
beyond those courts' reach. ${ }^{21}$ But the area of added jurisdiction that is most important to the present discussion, and the one focused on in the debate over the FCIA as having the greatest need for uniformity, was jurisdiction over patent litigation in the federal district courts.

Federal courts have had exclusive jurisdiction over the litigation of patent claims for most of this nation's history. ${ }^{22}$ As specified under both pre-FCIA and current law, federal district courts have exclusive jurisdiction over "any civil action arising under any Act of Congress relating to patents." ${ }^{23}$ Prior to the Federal Circuit's creation, appeals from such civil actions were sent to the RCCOA in which the district court was located. ${ }^{24}$

Under the pre-Federal Circuit system, though, the RCCOAs varied significantly in their handling of patent cases and in their general patent jurisprudence. ${ }^{25}$ From 1945 to 1957 , for example, "a patent was twice as likely to be held valid and infringed in the Fifth Circuit than in the Seventh Circuit, and almost four times more likely to be enforced in the Seventh Circuit than in the Second Circuit."26 This situation was aptly summarized by the Reports of the House and Senate Judiciary Committees on the bills that would become the FCIA,${ }^{27}$ which appear to be the most authoritative indications of Congress's intent in creating the Federal Circuit. ${ }^{28}$ Both reports cited the Hruska Commission's ${ }^{29}$ conclusion "singl[ing] out patent law as an area in which the applica-

21. For example, the Federal Circuit was given exclusive appellate jurisdiction of "appeals from U.S. district courts in non-tort and non-tax actions against the United States for $\$ 10,000$ or less under the Little Tucker Act." Re, supra note 18, at 654 (citations omitted). The court was later granted appellate jurisdiction over varied subjects such as appeals from the Court of Veteran Appeals and from the General Accounting Office Personnel Appeals Board. See The United States Court of ApPEals for the Federal Circuit-A History 1982-1990, at 13-20 (Marion T. Bennett ed., 1991) [hereinafter HISTORY].

22. It appears that federal statutes have vested "exclusive jurisdiction of patent infringement litigation" in the federal courts at least since 1836, and possibly since 1800. Fla. Prepaid Postsecondary Educ. Expense Bd. v. Coll. Sav. Bank, 527 U.S. 627, 648 \& n. 1 (1999) (Stevens, J., dissenting).

23. 28 U.S.C. $\S 1338$ (a) (2000). In this Article, "any Act of Congress relating to patents" will be referred to as "patent law" or "the patent laws."

24. See Re, supra note 18 , at 654 .

25. See Taylor, supra note 4, at 11; Rochelle Cooper Dreyfuss, The Federal Circuit: A Case Study in Specialized Courts, 64 N.Y.U. L. Rev. 1, at 6-7 (1989).

26. Dreyfuss, supra note 25 , at 7 .

27. H.R. REP. No. 97-312 (1981); S. REP. No. 97-275 (1981).

28. The Supreme Court, for example, has "repeatedly stated" that "in surveying legislative history" the "authoritative source for finding the Legislature's intent lies in the Committee Reports on the bill, which 'represen[t] the considered and collective understanding of those Congressmen involved in drafting and studying proposed legislation." Garcia v. United States, 469 U.S. 70, 76 (1984). Admittedly, "extensive hearings" were held and several bills were introduced in both the House and Senate during in the 95th, 96th, and 97th Congresses. History, supra note 21, at 11. But in the Congress which passed the FCIA - the 97th Congress-these were the only two committee reports. See id. at $7 \mathrm{n} .9$. Moreover, beyond the specific language that the FCIA added to Title 28 and what can be inferred from the structural modifications it produced, there is little evidence of explicit legislative intent within the text of the FCIA itself.

29. The Hruska Commission, formally known as the Commission on the Revision of the Federal Court System, was created by Congress to investigate reforms to the federal judicial system. See 
tion of the law to the facts of a case often produces different outcomes in different courtrooms in substantially similar cases." ${ }^{30}$

This disparity caused certain RCCOAs to develop reputations as "pro-patent and ... anti-patent." ${ }^{31}$ As a result, "forum shopping was rampant" as patentees "scramble[d]" to have their cases heard in the former, and alleged patent infringers "scramble[d]" to fix suits in the latter. ${ }^{32}$ Given the large stakes that typically run with patent litigation, ${ }^{33}$ the result was to be expected: "expensive venue fights designed to steer the ultimate appeal to the regional circuit most likely to rule favorably on the merits for the winner ...."34 The Hruska Commission's pointed assessment was that this situation "demean[ed] the entire judicial process and the patent system as well. ${ }^{\prime 35}$ It was in view of this situation that Congress decided to consider legislation to resolve the "special problem in patent law." ${ }^{36}$ Witnesses who appeared, for example, before the House Judiciary

HistoRY, supra note 21, at 3-4. Its broad recommendation to create a National Court of Appeals below the Supreme Court but above the pre-existing courts of appeals was never adopted. Id. at 4 . But its "broad studies ... confirmed that conflicts [in federal law] persisted, especially in the areas of federal tax and patent laws, because of the lack of nationally uniform resolution of issues in those areas." Id.

30. S. REP. No. 97-275, at 5 (1982), reprinted in 1982 U.S.C.C.A.N. 11, 15 (citing Commission on Revision of the Federal Court Appellate System, Structure and Internal Procedures: Recommendations for Change, 15, 144-57, reprinted in 67 F.R.D. 195, 214, 361-76 (1975)) [hereinafter Hruska Commission Report], quoted in Taylor, supra note 4, at 11; see also H.R. REP. No. 97-312, at 20 (1981).

31. H.R. REP. No. 97-312, at 20-21.

32. Id. at 21 (quoting Hruska Commission Report, supra note 27, at 152,67 F.R.D. at 320).

33. See, e.g., Kathleen M. Kedrowski \& Jennifer L. Knabb, An In-Depth Look at Historical Patent and Trademark Damages Trends, 20:3 Intell. Prop. L. Newsl. 6, 9 (2002) (noting that "from 1982 to 1989 , the average damages award [in a patent case] was slightly more than $\$ 6.6$ million" and "the median award was $\$ 785,000 ")$. In more recent years, such awards have only increased in value. See, e.g., id. (noting that "[f]rom 1990 through 2000, the average [patent damages award] ... gr[ew] at a multiple of over three, to about $\$ 24$ million," and the median award grew to $\$ 2.4$ million); Taylor, supra note 4 , at 12,16-17 (implying that the Federal Circuit has significantly increased patent value since its creation and stating that "[b]y any measure chosen, the economic importance of patent property in 2002 is greater by an order of magnitude than that of a generation ago"). Moreover, the permanent injunctions that typically follow a successful patent infringement case can put a competitor out of a particular line of business altogether. Perhaps the most notable example of this possibility is Polaroid's patent-infringement victory over Kodak, which "effectively kept Kodak out of the instant photography business." Robert W. Morris, Note, "Another Pound of Flesh": Is There a Conflict Between the Patent Exhaustion Doctrine and Licensing Agreements?, 47 RuTGERs L. REv. 1557, 1573 n.83 (1995) (citing Polaroid Corp. v. Eastman Kodak Co., 789 F.2d 1556, 1574 (Fed. Cir. 1986) (affirming the district court's grant of a permanent injunction against Kodak)).

34. Taylor, supra note 4, at 11; see also H.R. REP. No. 97-312, at 20 ("Patent litigation long has been identified as a problem area, characterized by undue forum-shopping and unsettling inconsistency in adjudications."').

35. H.R. ReP. No. 97-312, at 21 (citing Hruska Commission Report, supra note 30, at 152, 67 F.R.D. at 370). The Hruska Commission's findings "that patent cases are inconsistently adjudicated" were confirmed by the "great weight" of testimony that Congress heard in the 96th and 97th Congresses, including from "distinguished jurists, patent practitioners, and representatives of major technologicallyoriented business enterprises," testimony that "also supported the basic objective of providing for uniformity of doctrinal development in the patent area." S. REP. No. 97-275, at 5, 1982 U.S.C.C.A.N. at 15 .

36. Dreyfuss, supra note 25 , at 6 (citing S. REP. No. 97-275, at 5-6, 1982 U.S.C.C.A.N. at 15-16; Hruska Commission Report, supra note 30, at 15,67 F.R.D. at 220). 
Committee "repeatedly singled out" establishing "a single court to hear patent appeals" as "one of the most far-reaching reforms that could be made to strengthen the United States patent system in such a way as to foster technological growth and industrial innovation."37

To these ends, Congress created the Federal Circuit and granted it nationwide jurisdiction over appeals from patent cases brought in federal district courts, a type of litigation largely outside of the jurisdiction of its predecessor courts. ${ }^{38}$ The legislative history shows that, as a "centralized national court with exclusive appellate jurisdiction to hear cases arising under the patent laws," Congress believed the Federal Circuit would "insure "a more uniform interpretation of the patent laws and thus [contribute] meaningfully and positively to predicting the strength of patents.",39 By channeling "patent appeals" to a single court, Congress also intended to "eliminate the expensive, time-consuming and un-

37. H.R. REP. No. 97-312, at 20.

38. While the CCPA, for example, heard appeals from the Patent and Trademark Office (PTO), such appeals dealt primarily in this regard with issues of patentability; patent litigation in the district courts, however, produces not only corresponding issues of patent validity, but also issues of infringement and remedies. See Re, supra note 18 , at 653 \& n.14 (citing FCIA $\S 127$, codified at 28 U.S.C. $\S 1295(\mathrm{a})(4)(\mathrm{A})$ (2000), creating exclusive jurisdiction in the Federal Circuit over appeals from decisions of "the Board of Patent Appeals and Interferences of the United States Patent and Trademark Office with respect to patent applications and interferences," procedures which concern whether and to whom a patent should be granted); id. at 654 \& n.22 (citing FCIA § 127, codified at 28 U.S.C. $\S 1295(a)(1)$, establishing exclusive jurisdiction in the Federal Circuit over appeals from, inter alia, final decisions of the district courts involving actions for patent infringement, see 35 U.S.C. $\$ 271$ (2000) - in which the defense that a patent is invalid for failure to satisfy a statutory condition of patentability may be asserted, see 35 U.S.C. $\$ 282$ (2000)-as well as actions for damages and other remedies, see 35 U.S.C. $\$ 281$ et seq. (2000)). (Generally speaking, patentability refers to the standards used by the PTO to determine whether a patent should be granted, while patent validity refers to the standards used by courts to determine whether an issued patent should be invalidated. ALAN L. DURHAM, Patent Law Essentials 61-62 (1999). But the legal rules in each context are essentially the same, with a primary difference being that patent validity determinations must account for every issued patent's presumption of validity, which "can only be overcome by 'clear and convincing evidence' of invalidity." Id. at 62 (citations omitted). In contrast, "there is no presumption in the Patent Office that an application meets the requirements of patentability." Id.)

The Court of Claims did, however, hear one particular type of case in which issues of patent infringement and remedies were present-patent suits against the United States; these actions are now heard by the United States Court of Federal Claims. See 28 U.S.C. § 1498(a) (2000); Robishaw Eng'g, Inc. v. United States, 891 F. Supp. 1134, 1139-40 (E.D. Va. 1995) (noting that patentees cannot obtain damages from the Government in a normal patent infringement action in a district court, but must seek relief in the Court of Federal Claims) (citing 28 U.S.C. $\$ 1498(a)$ and Richmond Screw Anchor Co. v. United States, 275 U.S. 331, 343 (1928)). These suits differ from normal patent litigation in that, inter alia, "the patentee may not obtain an injunction against unauthorized use by the government" as it could from a private infringer; the patentee's remedy here is simply "his reasonable and entire compensation for such use and manufacture." Id. at 1139 \& n.5 (citing 28 U.S.C. $\S 1498(a)$ ).

39. Taylor, supra note 4, 11-12 (quoting Hearings on H.R. 6033, H.R. 6934, H.R. 3806 and H.R. 2414, Before the Subcomm. on Courts, Civil Liberties \& the Admin. of Justice of the House Comm. on the Judiciary, 96th Cong., at 797 (1980)); see also H.R. REP. No. 97-312, at 20 (asserting that the Federal Circuit "will provide nationwide uniformity in patent law" and "make the rules applied in patent litigation more predictable"); Dreyfuss, supra note 25, at 7 ("According to proponents of the legislation, channeling patent cases into a single appellate forum would create a stable, uniform law and would eliminate forum shopping. Greater certainty and predictability would foster technological growth 
seemly forum-shopping that characterizes litigation in the field." ${ }^{40}$ The legislative history shows that Congress identified other, more general benefits as well. ${ }^{41}$

Over the twenty years of its existence, the Federal Circuit has at least largely fulfilled its mandate of enhancing uniformity in patent jurisprudence. In her oft-cited article-cited, for example, by both separate opinions in Vornado-that was published just seven years after the Federal Circuit heard its first case, Professor Rochelle Cooper Dreyfuss concluded that the Federal Circuit

has begun to make patent law more accurate, precise, and coherent. Its ability to accomplish this task derives largely from the high volume of patent appeals that it hears, which gives the court an overview of the full range of issues and forces it to construct an integrated picture of the law as a whole. ${ }^{42}$

And more recent analysis indicates that the Federal Circuit has made even further progress in its efforts to achieve uniformity in patent appeals. One commentator, for example, has concluded that "[w]hile not always successful in simplifying the resolution of patent cases, the Federal Circuit has achieved considerable success in making the process more uniform and in strengthening the economic importance of patents to the American economy." ${ }^{43}$ Although some might argue that the increase in patent value reflects only a pro-patent bias in the Federal Circuit, "the court has strengthened patent rights on some fronts but required more [than RCCOA law did] of patent owners on others"; ${ }^{4}$ "[e]ven those who are highly critical of these increases in the value of patent rights and the use of exclusivity as a reward for invention must concede the Federal Circuit's substantial efforts to rationalize the process . ..."45

and industrial innovation and would facilitate business planning.") (citing, inter alia, Hruska Commission Report, supra note 30, at 15, 58-59, 67 F.R.D. at 220, 264-66).

40. H.R. ReP. No. 97-312, at 20; see also S. Rep. No. 97-275, at 5, 1982 U.S.C.C.A.N. at 15 ("[S]uch uniformity will reduce the forum-shopping that is common to patent litigation.").

41. For example, the House Report identifies a larger "appellate crisis" in the caseload of the RCCOAs, and notes that "the creation of the new court will ... reduce the workload of [other] appellate courts" by "rerout[ing] ... some of the most complex and time-consuming issues the courts consider." H.R. REP. No. 97-312, at 17, 23, 27. But see id. at 147 (dissenting views of Representative F. James Sensenbrenner, Jr.) (arguing that patent appeals "accounted for slightly less than 1 percent of the total appellate caseload" and thus do "not support the claim that a new national court will relieve docket congestion or ease case loads in the Court of Appeals"). Other identified benefits included increased efficiency through combining overlapping functions of the Court of Claims and CCPA. Id. at 23; S. REP. No. 97-275, at 5, 1982 U.S.C.C.A.N. at 15. Nevertheless, "the central purpose" of the Federal Circuit's creation was clear: "to reduce the widespread lack of uniformity and uncertainty of legal doctrine that exist[ed] in the administration of patent law." H.R. Rep. No. 97-312, at 23.

42. Dreyfuss, supra note 25, at 24.

43 Taylor, supra note 4 , at 11 .

44. Id. at 13 .

45. Id. at 12-13. Support for the Federal Circuit's performance is not unanimous, however. See Victoria Slind-Flor, Federal Circuit Judged Flawed, NAT'L L.J., Aug. 3, 1998, at A1 (discussing dispute among practitioners about the Federal Circuit's effectiveness). 


\section{B. THE SCOPE OF THE FEDERAL CIRCUIT'S PRE-VORNADO PATENT JURISDICTION}

\section{Relevant Jurisdictional Statutes and Early Jurisdictional Issues}

Nevertheless, a recurring question since the establishment of the Federal Circuit has been the scope of its appellate jurisdiction. ${ }^{46}$ Congress chose to set the court's jurisdiction over appeals in patent cases by reference to 28 U.S.C. $\S 1338(a)$ - the statute governing the federal district courts' authority to try those cases. More specifically, 28 U.S.C. $§ 1295(a)(1)$ grants the Federal Circuit exclusive jurisdiction over appeals from decisions in which the jurisdiction of the district court "was based, in whole or in part, on section 1338 of this title." The Federal Circuit's patent jurisdiction thus appears to turn explicitly on the existence of jurisdiction in the court below under $\S 1338$, which grants the district courts exclusive "original jurisdiction of any civil action arising under any Act of Congress relating to patents." 48

The use of "arising under" in $\S 1338$ (a) is strikingly similar to the corresponding language in the general federal question statute, 28 U.S.C. $\S 1331 .^{49}$ Consequently, an obvious question was whether jurisdiction under $\S 1338$ (a) would be determined in the same manner as under $\S 1331$-that is, by use of the well-pleaded complaint rule. ${ }^{50}$ That rule, of course, requires that the plaintiff's complaint clearly demonstrate on its face the presence of a federal question; absent this, a plaintiff cannot sue in federal court and a defendant cannot remove a case from state court to federal court. ${ }^{51}$ The rule's roots run deep: Since at least 1887 , federal question jurisdiction has been principally, if not

46. See, e.g., Emmette F. Hale, III, The 'Arising Under' Jurisdiction of the Federal Circuit: An Opportunity for Uniformity in Patent Law, 14 FLA. Sr. U. L. Rev. 229, 265 (1986) (urging the Federal Circuit to abandon jurisdictional principles, such as the well-pleaded complaint rule, in order to exercise its jurisdiction over all appeals containing substantial patent issues); John Donofrio \& Edward C. Donovan, Christianson v. Colt Industries Operating Corp.: The Application of Federal Question Precedent to Federal Circuit Jurisdiction Decisions, 45 AM. U. L. Rev. 1835, 1899-1900 (1996) (arguing that the concepts of "arising under" jurisdiction and the well-pleaded complaint rule should be interpreted broadly to allow the Federal Circuit to fulfill Congress's goal of "unify[ing] patent law" and to "increase the predictability of the Federal Circuit's jurisdiction").

47. 28 U.S.C. $\$ 1295(a)(1)(2000)$.

48. 28 U.S.C. $\$ 1338(a)(2000)$.

49. "The district courts shall have original jurisdiction of all civil actions arising under the Constitution, laws, or treaties of the United States." 29 U.S. C. $\$ 1331$ (2000).

50. See Hale, supra note 46, at 229-30, 238-39 (contending that even though the well-pleaded complaint rule is used to determine "arising under" jurisdiction under 28 U.S.C. $\S 1331$, "because of the legislative history and public policy considerations underlying the Federal Circuit, the well-pleaded complaint rule should not be employed to determine the 'arising under' jurisdiction of the Federal Circuit").

One reason why the full scope of $\S 1338$ (a) relative to $\S 1331$ may have taken so long to be judicially developed is that, prior to the creation of the Federal Circuit, once a case was in federal court "the issue of whether the district court's jurisdiction was based on .... 1331 or $\S 1338$ was a distinction without a difference with respect to appellate jurisdiction; both actions were brought in federal district court, and both were appealed to the regional circuit court." Donofrio \& Donovan, supra note 46, at 1851.

51. ERWin Chemerinsky, Federal Jurisdiction 276-78 (4th ed. 2003). 
entirely, determined by the plaintiff's well-pleaded complaint. ${ }^{52}$ While the interpreted scope of "arising under" in federal question statutes is undoubtedly less broad than the Constitution allows, and may be based more on "history than logic," the well-pleaded complaint rule has been consistently reaffirmed. ${ }^{53}$ And since the test focuses on what claims are brought in the complaint by the plaintiff and not on the defendant's actions, it is easy to see why the introduction of a federal defense or counterclaim by a defendant has been long considered by lower courts and commentators as insufficient to confer $\S 1331$ jurisdiction ${ }^{54}$ - even though the Supreme Court had not specifically addressed the question with regard to counterclaims before Vornado. ${ }^{55}$

In view of this precedent, it would seem that so long as "arising under" was construed no more narrowly in $\S 1338$ (a) than in $\S 1331$, the Federal Circuit was at least assured of hearing appeals of all cases in which the plaintiff brought a patent claim. But there has also been a belief throughout the Federal Circuit's existence that the unique reasons for which the court was established might allow its jurisdiction to be interpreted more broadly than what the well-pleaded complaint rule would seem to permit. ${ }^{56}$ In particular, questions arose as to whether the Federal Circuit's exclusive jurisdiction might also encompass cases where a patent defense to a nonpatent claim was raised or a patent counterclaim was brought. ${ }^{57}$ While dicta from early Federal Circuit cases indicated that the court would have jurisdiction based only on a nonfrivolous compulsory counterclaim, prior to the cases discussed below it had never so held. ${ }^{58}$

\section{Christianson: The Supreme Court Addresses Jurisdiction over Patent Issues}

In 1988, the Supreme Court resolved the former jurisdictional question as it related to patent defenses in Christianson v. Colt Industries Operating Corp. ${ }^{59}$ and held that the Federal Circuit could not exercise jurisdiction over an appeal based solely on the presence of a patent issue ${ }^{60}$-more particularly, an issue of

52. Franchise Tax Bd. v. Constr. Laborers Vacation Trust, 463 U.S. 1, 9-10 (1983).

53. Id. at $4,8 \mathrm{n} .8,10,11 \mathrm{n} .9$ (collecting Supreme Court cases utilizing the rule in different contexts).

54. See, e.g., Chemerinsky, supra note 51, at 277 ("A federal law issue raised in the defendant's answer or counterclaim is not a basis for removal of a case from state to federal court if there is not a federal question presented in the plaintiff's complaint.").

55. Holmes Group, Inc. v. Vornado Air Circulation Sys., Inc., 535 U.S. 826, 831 (2002).

56. See, e.g., Dreyfuss, supra note 25, at 55 ("If the [Federal Circuit's] ability to function effectively as a court turns on its opportunity to consider cases raising broader competition issues, then its adjudicatory authority should be interpreted to maximize its chances of hearing those kinds of disputes... . Thus, instead of limiting its appellate jurisdiction to cases in which the patent issue appears on the face of a well-pleaded complaint, the court could be permitted to review any case that raises a patent issue somewhere in the responsive pleadings.").

57. See, e.g., Hale, supra note 46, at 265 (arguing that the Federal Circuit should "exercis[e] jurisdiction over all appeals from cases that contain substantial patent issues").

58. See Aerojet-General Corp. v. Machine Tool Works, Oerlikon-Buehrle Ltd., 895 F.2d 736, 739-41

(Fed. Cir. 1990) (en banc).

59. 486 U.S. 800 (1988).

60. Id. at $808-09$. 
patent law that only appeared as part of plaintiff's argument against a nonpatent defense raised to plaintiff's nonpatent claim. ${ }^{61}$ Justice Brennan delivered the Court's unanimous opinion. ${ }^{62}$

In analyzing the proper test for $\S 1338$ (a) jurisdiction, the Court first noted that with respect to $\S 1338$ 's "precursor" statute, the Court

held long ago that in order to demonstrate that a case is one "arising under" federal patent law "the plaintiff must set up some right, title or interest under the patent laws, or at least make it appear that some right or privilege will be defeated by one construction, or sustained by the opposite construction of these laws." ${ }^{63}$

The Court then observed that its "cases interpreting identical language in other jurisdictional provisions," and specifically $\S 1331$, "have quite naturally applied the same test." ${ }^{\prime 64}$ That test is the well-pleaded complaint rule, which governs the general federal-question jurisdiction of federal district courts. ${ }^{65}$ This being established, the demands of "linguistic consistency"-a principle to which the Court has "historically adhered"-required application of the well-pleaded complaint rule to $\S 1338(a) .{ }^{66}$ Accordingly, § 1338(a) jurisdiction "only" extends to "those cases in which a well-pleaded complaint establishes either that federal patent law creates the cause of action or that the plaintiff's right to relief necessarily depends on resolution of a substantial question of patent law." ${ }^{, 67}$

Colt claimed, however, that jurisdiction in the Federal Circuit was appropriate, arguing that the congressional goals of uniformity and certainty in patent law "would be better served if the Federal Circuit's jurisdiction were to be fixed "by reference to the case actually litigated," instead of the "ex ante hypothetical assessment of the elements of the complaint that might have been dispositive" that the Court apparently used. ${ }^{68}$ But the Christianson Court rejected this claim. Acknowledging that Colt might be correct that its proposed test would better serve those broad congressional goals, the Court emphasized that Congress "determined the relevant focus ... when it granted jurisdiction to the Federal Circuit over 'an appeal from ... a district court ... if the jurisdiction of that

61. The root of the situation was concisely stated by the Federal Circuit in the case below: "Christianson asserted rights that arise under, and only under, antitrust law. Colt's defense is its trade-secret rights under state law. Christianson's argument against that defense is that Colt lost its secrets because it did not disclose them in its patent applications." Christianson v. Colt Indus. Operating Corp., 822 F.2d 1544, 1547 (Fed. Cir. 1987).

62. Christianson, 486 U.S. at 803.

63. Id. at 807-08 (quoting Pratt v. Paris Gas Light \& Coke Co., 168 U.S. 255, 259 (1897)).

64. Id. at 808 .

65. Id.

66. Id. at $808-09$.

67. Id.

68. Id. at 813. Arguably, since the patent issue was the focus of litigation in the case below, Dreyfuss, supra note 25 , at 33 , basing jurisdiction on the case actually argued would have rendered irrelevant the alternative theories in which patent law was not an essential element. 
court was based ... on section 1338." 69 To bolster this conclusion, the Court quoted legislative history from the act creating the Federal Circuit, which explained that the new circuit's jurisdiction, as defined by $\S 1338(a)$, was to be determined "in the same sense that cases are said to 'arise under' federal law for the purposes of federal question jurisdiction." 70

Applying the well-pleaded complaint rule to the facts at hand, the Court concluded that there was no claim "arising under" patent law. The first prong of the rule was not met, as patent law clearly did not create the plaintiff's antitrust claim (from which the patent issue stemmed). ${ }^{71}$ The Court further concluded that patent invalidity was not essential to each alternative theory underlying the antitrust claim in the complaint. Thus, the claim also did not meet the second prong of the well-pleaded complaint rule. ${ }^{72}$

\section{Post-Christianson Cases Dealing with Jurisdiction over Patent Counterclaims}

Christianson was probably not a huge surprise-in fact, the Federal Circuit itself initially had concluded that it lacked such jurisdiction, ${ }^{73}$ and had only taken the case in an attempt to end what the Supreme Court described as a "game of jurisdictional ping-pong." 74 But because Christianson did not involve a separate patent counterclaim brought by the defendant, it arguably did not fully resolve the question of whether the Federal Circuit could use the presence of such a counterclaim to exercise jurisdiction, and whether that question's answer depended on whether the counterclaim was compulsory or permissive.

In the 1991 case of Aerojet-General Corp. v. Machine Tool Works, OerlikonBuehrle Ltd., ${ }^{75}$ the en banc Federal Circuit explicitly addressed this question with respect to non-frivolous compulsory patent counterclaims. ${ }^{76}$ The Aerojet court held that that it did have appellate jurisdiction over a case based solely on the presence of a compulsory patent counterclaim, reaffirming its pre-

69. Christianson, 486 U.S. at 813-14.

70. Id. at 814 (quoting H.R. REP. No. 97-312, at 41 (1981)).

71. Id. at 809 (citing Franchise Tax Bd. v. Constr. Laborers Vacation Trust, 463 U.S. 1, 10 (1983)).

72. Id. at $810-12$.

73. See id. at 806 .

74. Id. at 819 . As the Supreme Court explained it:

[T] he Federal Circuit ... [initially] concluded that it lacked jurisdiction and issued an unpublished order transferring the appeal to the Court of Appeals for the Seventh Circuit. The Seventh Circuit, however, raising the jurisdictional issue sua sponte, concluded that the Federal Circuit was "clearly wrong" and transferred the case back. The Federal Circuit, for its part, adhered to its prior jurisdictional ruling, concluding that the Seventh Circuit exhibited "a monumental misunderstanding of the patent jurisdiction granted this court," and was "clearly wrong[.]" Nevertheless, the Federal Circuit proceeded to address the merits in the "interest of justice," and reversed the District Court. We granted certiorari ... .

Id. at 806-07 (citations omitted).

75. 895 F.2d 736 (Fed. Cir. 1990) (en banc).

76. Id. at 737 . 
Christianson dicta to that effect. ${ }^{77}$

After an initial discussion of those dicta and the broad congressional purposes in creating the Federal Circuit, the court briefly analyzed the effect of the Supreme Court's holding in Christianson. It concluded that because Christianson involved "patent law issues raised only as a defense" that case was "clearly distinguishable" from a situation involving a patent claim brought as a counterclaim. ${ }^{78}$ The court saw no conflict between the well-pleaded complaint rule as properly applied to bar jurisdiction over a patent defense and its "holding that this court has appellate jurisdiction when a nonfrivolous well-pleaded compulsory patent law counterclaim is present in a case originally and properly filed in the district court."79 According to the Aerojet court, "the Justices [in Christianson] did not intend to make a rigid application of the well-pleaded complaint rule a Procrustean bed for this court's jurisdiction." 80

The court offered four reasons why the well-pleaded complaint rule did not bar jurisdiction in this case. First, the patent counterclaim at issue, "had it been filed as a complaint, would fully comply with the well-pleaded complaint rule." 81 The court concluded that "it would seem at best incongruous" to deny jurisdiction when the same well-pleaded patent infringement claim was filed in "a pleading labeled "counterclaim.",82

Second, because the patent counterclaim was "a separate, well-pleaded claim with its own jurisdictional basis" under $\S 1338$, "reliance upon a counterclaim with its own appeal-directing basis $(\S 1338)$ as invoking our appellate jurisdiction accords with the well-pleaded complaint rule rightly understood." ${ }^{83}$ The court placed particular emphasis on language from Christianson explaining that the well-pleaded complaint rule "focuses on claims, not theories." 84 It also relied on the fact that "counterclaims are normally filed at the pleading stage," which complied with "the early-setting-of-the-appeal-route advantage of the [well-pleaded complaint] rule ..."85 On this point, it also noted that the Supreme Court had never held that a counterclaim could not establish district court jurisdiction. $^{86}$

Third, the court maintained that this holding did not conflict "with Congress" indication that cases would be within our jurisdiction in the same sense that cases are said to "arise under" federal law for purposes of federal question jurisdiction." 87 The court commented that "courts have frequently looked to

\footnotetext{
77. Id. at $740-41$.

78. Id. at 741 .

79. Id.

80. Id.

81. Id. at 742

82. Id.

83. Id.

84. Id. (quoting Christianson, 486 U.S. at 810 ).

85. Id. (citation omitted).

86. Id.

87. Id. (quoting H.R. REP. No. 97-312, at 41 (1981)).
} 
counterclaims in determining that cases arise under federal law for purposes of federal question jurisdiction without regard to the complaint," and cited cases in which courts had relied on the independent jurisdiction of a counterclaim when a complaint was jurisdictionally defective or had been dismissed. ${ }^{88}$ Christianson did not overrule those cases, since "the phrase 'well-pleaded complaint' is merely the name of the rule, not a statement of a principle of law." 89

Fourth, the "the basic purpose underlying the well-pleaded complaint rule is to avoid "potentially serious federal-state conflicts," a concern that did not apply when addressing an appeal "in a case already properly in the federal system." 90 In particular, the court noted that "the plaintiff's right to choose a federal trial forum has already been fully exercised" once he files in federal court. ${ }^{91}$ It concluded by saying that the use of "the ramifications of the wellpleaded complaint rule to limit our appellate jurisdiction in every case by an exclusive focus on the complaint and a compelled disregard of compulsory counterclaims for patent infringement, would disserve the intent of Congress in creating this court." 92

The court also used legislative history to justify its conclusion. It concluded that the congressional goal of nationwide uniformity in patent law and the benefits that were to result from that uniformity "are facilitated when appeals in cases involving nonfrivolous claims arising under the patent laws, whether found in complaints or in compulsory counterclaims, are directed to this court." ${ }^{\text {93 }}$ It ended this part of the opinion by referring to the rule that "a construction that undermines a statute's goal cannot stand," and stated that this canon supported its conclusion. ${ }^{94}$

Seven years later, in DSC Communications Corp. v. Pulse Communications, Inc. ${ }^{95}$ the Federal Circuit formally broadened its interpretation of $\S 1338(a)$ to include non-frivolous permissive counterclaims. In that case, the Federal Circuit, observing that the congressional policy underlying $\S 1295(a)(1)$ was "to ensure uniform resolution of patent disputes," saw "no sufficient basis in the language or purpose of [that section] to distinguish between compulsory and permissive counterclaims." ${ }^{96}$ But even well before DSC Communications-one year after Aerojet, in fact-at least one RCCOA had already extended the Aerojet logic and transferred cases with permissive patent counterclaims to the

88. Id. at $742-43$.

89. Id. at 743 .

90. Id. (quoting Franchise Tax Bd. v. Constr. Laborers Vacation Trust, 463 U.S. 1, 10 (1983)).

91. Id. at 744 .

92. Id.

93. Id.

94. Id. at 745 (citing Cmty, for Creative Non-Violence v. Reid, 490 U.S. 730, 749-50 (1989)).

95. 170 F.3d 1354 (Fed. Cir. 1999).

96. Id. at 1359. Interestingly, the court made no attempt to explain how permissive counterclaims fell under $\S 1338(a)$, on which its $\S 1295(a)(1)$ appellate jurisdiction would appear to depend. 
Federal Circuit. ${ }^{97}$ Thus, by 2002, many patent litigators had "long taken for granted" that appeals of patent counterclaims would be heard by the Federal Circuit. $^{98}$

\section{VORNADO: A NEW JURISDICTIONAL RULE FOR PATENT COUNTERCLAIMS}

\section{Procedural History}

Despite the Federal Circuit's previous conclusions to the contrary, the Supreme Court in Holmes Group, Inc. v. Vornado Air Circulation Systems, Inc. ${ }^{99}$ held that the Federal Circuit could not assert jurisdiction over the appeals of cases based solely on the presence of a patent counterclaim. ${ }^{100}$ Holmes, the plaintiff below, had filed suit in federal district court seeking, inter alia, a declaratory judgment of noninfringement of Vornado's trade dress. The Tenth Circuit, in an earlier case against a different potential infringer, had found this trade dress unprotectable. ${ }^{101}$ Holmes asserted no patent claim, but Vornado responded with what the Supreme Court later described as a compulsory counterclaim for patent infringement. ${ }^{102}$ Relying on the Tenth Circuit's earlier ruling, the district court awarded summary judgment to Holmes on its declaratory judgment claim and stayed proceedings on the patent counterclaim. ${ }^{103}$ In doing so, it rejected Vornado's argument that an intervening Federal Circuit decision, Midwest Industries, Inc. v. Karavan Trailers, Inc., ${ }^{104}$ constituted a change in the law that would allow relitigation of Vornado's trade dress claim. Although the Tenth and Federal Circuits' respective trade dress rulings represented a "clear conflict in the substantive law of the circuits," the district court concluded that collateral estoppel nevertheless applied. ${ }^{105}$

Vornado then appealed-not to the Tenth Circuit, which encompassed the particular district court and to which appeals of nonpatent cases would have normally gone, but instead to the Federal Circuit. ${ }^{106}$ The Federal Circuit, in a two-page unpublished order, summarily vacated and remanded the district court's ruling, ${ }^{107}$ appearing to base its jurisdiction for doing so on the presence

97. Unique Concepts, Inc. v. Manuel, 930 F.2d 573, 575 (7th Cir. 1991) (Easterbrook, J.) (transferring an appeal to the Federal Circuit based on a permissive counterclaim under patent law, using the Aerojet logic).

98. See Cases and Recent Developments, supra note 7, at 195.

99. 535 U.S. 826 (2002).

100. Id. at 832 .

101. Id. at 828 .

102. Id.

103. Id.

104. 175 F.3d 1356 (Fed. Cir. 1999).

105. Holmes Group, Inc. v. Vornado Air Circulation Sys., 93 F. Supp. 2d 1140, 1143 (D. Kan. 2000).

106. See Vornado, 535 U.S. at 829.

107. Holmes Group, Inc. v. Vornado Air Circulation Sys., Inc., 13 Fed. Appx. 961, 2001 WL 712760 (Fed. Cir. 2001) (non-precedential). 
of a compulsory patent counterclaim. ${ }^{108}$ The Federal Circuit explained that it remanded the case to allow the district court to consider "whether the "change in the law' exception to collateral estoppel" applied ${ }^{109}$ in light of the Supreme Court's decision in TrafFix Devices, Inc. v. Marketing Displays, Inc. ${ }^{110}$ which issued while the appeal from the district court to the Federal Circuit was pending and which resolved the split between the Tenth and Federal Circuits. ${ }^{11}$

Holmes petitioned the Supreme Court for certiorari, which was granted. ${ }^{112}$ In its briefs before the Court, Holmes primarily argued that Christianson held that the "arising under" test for $\S 1338$ (a) jurisdiction is the same as that for $\S 1331$ jurisdiction, and cited numerous lower court cases holding that counterclaims do not satisfy the well-pleaded complaint rule. ${ }^{113}$ Vornado, on the other hand, primarily argued that the Supreme Court itself had never ruled that counterclaims did not arise under either $\S 1331$ or $\S 1338$. It distinguished Christianson as concluding only that the Federal Circuit could not exercise jurisdiction based solely on a patent defense, and as thus leaving open the issue before the Court as to patent counterclaims. In addition, Vornado claimed that the well-pleaded complaint rule requires only that the right to sue in federal court cannot depend on the defense and that the court's jurisdiction must be invoked at the time the claim is brought. In light of those principles and the fact that only a choice between two federal appellate forums was at stake, Vornado argued that $\S 1338$ (a) (as referenced by $\S 1295(a)(1)$ ) was properly read to encompass a compulsory patent counterclaim. ${ }^{114}$ Interestingly, each party accused the other of arguing for a jurisdictional rule that would have placed it in the court of appeals with the

108. See Vornado, 535 U.S. at 828-29. The Supreme Court in Vornado, addressing the argument briefed by the respondent, analyzed the case as if this was the asserted jurisdictional basis, id. at 830 , but the Federal Circuit's opinion does not explicitly make this characterization.

109. Id. at 829 .

110. 532 U.S. 23 (2001).

111. See Vornado, 535 U.S. at 829. As explained by the district court in Vornado, "[i]t is well established that an intervening change in the law can be a sufficient basis for declining to apply collateral estoppel." 93 F. Supp. 2d at 1143 (citing, inter alia, Bingaman v. Dep't of Treasury, 127 F.3d 1431, 1438 (Fed. Cir. 1997) ("In a number of cases, this court and others have held that a significant change in the 'legal atmosphere'- whether in the form of new legislation, a new court decision, or even a new administrative ruling-can justify a later court's refusal to give collateral estoppel effect to an earlier decision.")). Nevertheless, the district court had rejected Vornado's claim that the split between the Tenth and Federal Circuits on trade dress law created by the latter's Midwest decision constituted a sufficient change in the law to invoke the exception. Id. at 1143. In particular, the court had held that collateral estoppel should apply "[r]egardless of which Court of Appeals would have jurisdiction," id. at 1143 n.2, and had concluded that there was no evidence that the Tenth Circuit had or would change its trade dress law in view of Midwest. See id. at 1143-44. But TrafFix's resolution of that split, and in a manner that foreclosed applying the precise rule of law previously used by the Tenth Circuit, arguably was sufficient.

112. Holmes Group, Inc. v. Vornado Air Circulation Sys., Inc., 534 U.S. 1016 (2001).

113. See Petitioner's Brief, Vornado, No. 01-408, 2002 WL 24105, at *15-16, 20 n.15 (Jan. 4, 2002); Reply Brief, Vornado, No. 01-408, 2002 WL 417307, at*2-3 n.3 (Mar. 12, 2002).

114. See Respondent's Brief, Vornado, No. 01-408, 2002 WL 225890, at*10-14 (Feb. 11, 2002). 
most favorable trade dress law. ${ }^{115}$

\section{Majority Opinion}

In an opinion written by Justice Scalia and joined in full by five other justices, the Supreme Court sided with Holmes. After examining the statutory basis for the Federal Circuit's patent jurisdiction, the Court noted that "[s]ection 1338(a) uses the same operative language as" $\$ 1331 .{ }^{116}$ Quoting Christianson, the Court again concluded that "'linguistic consistency' requires application of the same test to determine whether a case arises under $\S 1338(a)$ as under $\S 1331 . " 117$ Accordingly, and as previously held in Christianson, the appellate jurisdiction of the Federal Circuit in patent cases is defined by the well-pleaded complaint rule, and thus turns on whether the complaint itself alleges a claim arising under the patent laws. ${ }^{118}$ Because it was "undisputed that petitioner's well-pleaded complaint did not assert any claim arising under federal patent law," jurisdiction over the appeal was not proper in the Federal Circuit. ${ }^{119}$

The Court then responded to Vornado's claim-apparently similar to the Federal Circuit's Aerojet conclusion-that the "well-pleaded-complaint rule, properly understood," could be satisfied by a counterclaim. ${ }^{120}$ The Court admitted that its prior cases in this area had only required it to decide whether federal defenses could establish "arising under" jurisdiction; "[n]evertheless, those cases were decided on the principle that federal jurisdiction generally exists 'only when a federal question is presented on the face of the plaintiff's properly pleaded complaint." 121 The Court noted its previous rejection of "proposals that "the answer as well as the complaint ... be consulted before a determination [is] made whether the case "ar[ises] under" federal law...."'122 As the Court had held almost ninety years earlier, "whether a case arises under federal patent law "cannot depend on the answer." ${ }^{123}$ Since counterclaims appear in the answer, the Court concluded that they could not serve as a basis for "arising under" jurisdiction, and cited for support several lower court cases and a

115. See Respondent's Brief at *24 ("Petitioner's conduct below, on the other hand, was precisely the type of forum-shopping Congress intended to prevent. Recognizing that the law of the Federal Circuit was unfavorable to its position, petitioner manipulated jurisdictional rules by bringing a declaratory judgment action that conveniently omitted a patent law claim integral to the case."); Reply Brief at *1 ("Respondent urges this Court to expand drastically the exclusive appellate jurisdiction of the Federal Circuit, not on the basis of any existing or non-speculative threat to the 'uniformity' of federal patent law, but simply to improve this particular Respondent's chances of mounting a successful collateral attack on the final judgment of 'trade dress' invalidity rendered" by the Tenth Circuit).

116. Vornado, 535 U.S. at 829.

117. Id. at 830 .

118. Id.

119. Id.

120. Id.

121. Id. at 831 (quoting Caterpillar Inc. v. Williams, 482 U.S. 386, 392 (1987)).

122. Id. (quoting Franchise Tax Bd. v. Constr. Laborers Vacation Trust, 463 U.S. 1, 10-11 n.9 (1983)).

123. Id. (quoting The Fair v. Kohler Die \& Specialty Co., 228 U.S. 22, 25 (1913)). 
respected treatise to that effect. ${ }^{124}$

The Vornado court further supported its conclusion by explaining why "[a]1lowing a counterclaim to establish 'arising under' jurisdiction would also contravene the longstanding policies underlying our precedents." ${ }^{125}$ First, the well-pleaded complaint rule establishes the plaintiff as "the master of the complaint," who can "by eschewing claims based on federal law" ensure that his case stays in state court. ${ }^{126}$ Allowing counterclaims to create "arising under" jurisdiction would preclude such control, "leav[ing] acceptance or rejection of a state forum to the master of the counterclaim."127 Such a rule would allow "a defendant to remove a case brought in state court under state law, thereby defeating a plaintiff's choice of forum, simply by raising a federal counterclaim." ${ }^{28}$ Second, the rule would interfere with the "[d]ue regard for the rightful independence of state governments' that our cases addressing removal require" by "radically expand[ing] the class of removable cases." 129 Finally, Vornado's proposed rule would defeat goals of "clarity and ease of administration" behind the rule, as it would allow "responsive pleadings by the defendant" to establish "arising under" jurisdiction. ${ }^{130}$

The Court also rejected Vornado's alternative suggestion that "arising under" should be interpreted differently when determining the Federal Circuit's jurisdiction so as to effectuate the congressional goal of uniformity in patent law. While recognizing that goal, the Supreme Court found it insufficient justification for changing the meaning of $\S 1338$ (a) for the purposes of $\S 1295(a)(1)$, but not when $\S 1338(a)$ was invoked on its own. ${ }^{131}$ The Court noted that the phrase "arising under" is not "some neologism that might justify our adverting to the general purpose of the legislation, but rather a term familiar to all law students as invoking the well-pleaded-complaint rule"; it concluded that the "task here is not to determine what would further Congress's goal of ensuring patent law uniformity, but to determine what the words of the statute must fairly be understood to mean."132 Adopting respondent's argument that $\S 1338$ (a) should be interpreted differently when it was referred to by $\S 1295(\mathrm{a})(1)$ than it otherwise would be, "would be an unprecedented feat of interpretive necromancy." 133

124. Id. (citing In re Adams, 809 F.2d 1187, 1188 n.1 (5th Cir. 1987); FDIC v. Elefant, 790 F.2d 661, 667 (7th Cir. 1986); Takeda v. N.W. Nat'l Life Ins. Co., 765 F.2d 815, 822 (9th Cir. 1985); 14B Charles A. Wright et al., Federal Practice and Procedure § 3722, at 402-14 (3d ed. 1998)).

125. Vornado, 535 U.S. at 831.

126. Id. at 831 (quoting Caterpillar, 482 U.S. at 398-99).

127. Id.

128. Id. at $831-32$.

129. Id. at 832 (quoting Shamrock Oil \& Gas Corp. v. Sheets, 313 U.S. 100, 109 (1941)).

130. Id. (citing Franchise Tax Bd., 463 U.S. at 11).

131. Id. at 832-33.

132. Id. at 833 .

133. Id. 


\section{Concurring Opinions}

Justice Stevens concurred in the opinion of the Court except for part II-B (in which the "necromancy" discussion occurred), largely agreeing with the majority's reasoning. ${ }^{134}$ In particular, he agreed that "each of the three policies that the Court has identified as supporting the 'well-pleaded-complaint' rule ... points in the same direction with respect to appellate jurisdiction.",135

But Justice Ginsburg, joined by Justice O'Connor, only concurred in the judgment. ${ }^{136}$ Justice Ginsburg adopted the Federal Circuit's reasoning in Aerojet and concluded that the Federal Circuit had exclusive appellate jurisdiction over a case "when the claim stated in a compulsory counterclaim 'aris[es] under' federal patent law and is adjudicated on the merits by a federal district court. ..." 137 Justice Ginsburg cited the Aerojet court's observation that a patent infringement counterclaim, "unlike a patent issue raised only as a defense," has as its own "independent jurisdictional base 28 U.S.C. $\S 1338$, i.e., such a claim discretely "arises under the patent laws." "138 Interestingly, Justice Ginsburg contended that "a plaintiff's choice of trial forum" was not at issue; rather, "[t]he sole question presented here concerns Congress' allocation of adjudicatory authority among the federal courts of appeals." 139 She believed that "giving effect" to the congressional goals in creating the Federal Circuit "to eliminate forum shopping and to advance uniformity in ... patent law" 140 requires that the test for $\S 1338$ (a)—at least for determining the Federal Circuit's appellate jurisdiction-be whether a patent counterclaim was "actually adjudicated. Simply because she concluded that the patent counterclaim had not been so adjudicated, she concurred in the judgment of the court. ${ }^{141}$

\section{ANALYSIS OF VORNADO: DID CONGRESS INTEND FOR PATENT-INFRINGEMENT COUNTERCLAIMS TO “ARISE UNDER" PATENT LAW?}

As seen from the discussion above, the Supreme Court in both Christianson and Vornado relied heavily on the similarity between the operative phrases of $\S \S 1331$ and 1338(a), and used the principle of "linguistic consistency" to

134. Id. at 834,839 (Stevens J., concurring in part and concurring in the judgment). While agreeing with the majority's holding that the Federal Circuit's appellate jurisdiction could not be determined by the presence of a counterclaim, Justice Stevens did not believe that interpreting "arising under" in $\S 1338$ to allow such jurisdiction rose to the level of "interpretive necromancy," and found "it unnecessary and inappropriate to slight the contrary reasoning of the Court of Appeals." Id. at $835 \&$ n.1. In addition, Justice Stevens expressed his concern that the Court had left unclear the question of when the jurisdiction of the Federal Circuit was fixed, and contended that this time should be the same as for other appellate courts: the time the notice of appeal was filed. Id. at 834-35.

135. Id. at 837 .

136. Id. at 839 (Ginsburg, J., concurring in the judgment).

137. Id. (emphasis added).

138. Id. at 839-40 (citing Aerojet-General Corp. v. Machine Tool Works, Oerlikon-Buehrle Ltd., 895

F.2d 736, $741-44$ (Fed. Cir. 1990)).

139. Id. at 840 .

140. Id. (citing Dreyfuss, supra note 25 , at $30-37$ ).

141. Id. 
require that the same test be applied to both sections. In the context of federal question jurisdiction, however, it is difficult to imagine a more ironic tool of statutory construction. This is, after all, an area where virtually-indistinguishable operative language has been read to mean one thing in the Constitution, and quite another in jurisdictional statutes. ${ }^{142}$

That being said, did Vornado reach the right result? And in that regard, one might rightfully ask, what did Congress intend? Justice Scalia's majority opinion avoids this discussion altogether. In fact, Justice Scalia goes so far as to say-consistent with his overall philosophy of statutory construction ${ }^{143}$-that the issue of what Congress meant to have $\S 1338$ (a) and $\S 1295$ (a)(1) cover is not even the ultimate question. Nevertheless, it is useful to step back and look at the legislative history ${ }^{144}$ to attempt to determine what congressional intent might have been. In view of the case discussion above, this history should be examined to find answers to two particular questions: First, how did Congress intend for the Federal Circuit's jurisdiction to be determined and, in particular, what test did Congress intend to be used? Second, did Congress expect that counterclaims would meet that test? This examination will aid in seeing to what extent, if any, explicit consideration of legislative intent in Vornado might have produced a different result. It will also be useful in subsequently addressing the problems Vornado creates.

\section{How Did Congress Intend the Federal Circuit's Patent Jurisdiction to Be Determined?}

What tests could Congress have envisioned being applied to determine the Federal Circuit's jurisdiction? Fortunately, an examination of the legislative history points to at least three possibilities. As referenced above in the discus-

142. Compare U.S. ConST. art. III, § 2, cl. 1 ("The judicial Power shall extend to all Cases, in Law and Equity, arising under this Constitution, the Laws of the United States, and Treaties made, or which shall be made, under their Authority") with 28 U.S.C. $\$ 1331$ ("The district courts shall have original jurisdiction of all civil actions arising under the Constitution, laws, or treaties of the United States"); see, e.g., CHEMERINSKY, supra note 51, at 267 ("Although the statutory language is virtually identical to that found in the Constitution, the Supreme Court has adopted markedly different interpretations of these provisions.").

143. See Antonin Scalia, A Matter of Interpretation: Federal Courts and the Law 16-23 (Amy Gutmann ed., 1997) (explaining Justice Scalia's views on the use of legislative history in statutory interpretation and agreeing with Justice Holmes's conclusion that "[w]e do not inquire what the legislature meant; we ask only what the statute means").

144. Of course, there has been much debate about whether the examination of legislative history to ascertain congressional intent is proper in statutory interpretation. In examining the history here, I am not endorsing a particular view on this question. But more important, the relevance of congressional intent to the interpretation of federal statutes is distinct from the relevance of such intent to the choice-of-law issues underlying the question of whether other inferior federal courts should defer to the Federal Circuit's decisional law interpreting patent statutes. The latter question is independent of the statutory interpretation methods used in any particular Federal Circuit case. And since inferior courts exist at Congress's discretion, it seems appropriate that they should look to a sister court for guidance in interpreting statutes passed by Congress, if doing so serves Congress's larger intent for the federal judicial system. See infra Part III. 
sion of Christianson, the House Report specifically stated that "[c]ases will be within [the Federal Circuit's patent jurisdiction] in the same sense that cases are said to 'arise under' federal law for purposes of federal question jurisdiction." 145 By itself, this statement would seem almost determinative of the question; it provides powerful evidence of Congress's intent that the same jurisdictional tests apply to patent claims as apply to regular federal claims. The case for this interpretation becomes even stronger once one considers that an earlier Congress chose, and the FCIA Congress retained, the same operative language in $\S 1338$ as in $\S 1331$. And what comes next in the House Report makes this evidence stronger still. Immediately after the "same sense" passage quoted above, the House Report added "Contrast, Coastal States Marketing, Inc. v. New England Petroleum Corp., 604 F.2d 179 (2d Cir., 1979)." 46 This contrast is important because it is evidence that Congress knew of other potential tests and rejected them.

Coastal States involved an attempt to transfer an appeal from the Second Circuit to the Temporary Emergency Court of Appeals (TECA). The TECA had been granted "exclusive jurisdiction of all appeals from the district courts of the United States in cases and controversies arising under" the Economic Stabilization Act and the Emergency Petroleum Allocation Act of 1973 (collectively ESA). ${ }^{147}$ The appeal in Coastal States related to a district court's adjudication of a dispute over a regulation promulgated under the ESA. At issue was whether the appeal was "a case or controversy arising under the" ESA and, therefore, within the TECA's exclusive jurisdiction. ${ }^{148}$

The court noted that the division of jurisdiction between the TECA and the federal courts of appeals in cases involving ESA issues would depend "upon the scope of the TECA's exclusive jurisdiction." 149 Three possibilities were recognized. The first was "traditional 'arising under' jurisdiction." 150 The second possibility was "case" jurisdiction, in which the TECA's jurisdiction could be "broadly construed to include all cases involving any ESA issue, even if raised as a defense or in some other way that would not suffice for traditional 'arising under' jurisdiction." 151 The third and final possibility was "issue" jurisdiction, in which the TECA's exclusive jurisdiction only included ESA issues, "while leaving to the court of appeals all other issues in the same case." ${ }^{152}$ Based on several factors, the court concluded that the TECA had a "form of 'issue'

145. H.R. REp. No. 97-312, at 41 (1981), quoted in Christianson v. Colt Indus. Operating Corp., 486 U.S. 800, 814 (1988).

146. H.R. REP. No. $97-312$, at 41 .

147. Coastal States Mktg., Inc. v. New Eng. Petroleum Corp., 604 F.2d 179, 182 (2d Cir. 1979) (citation omitted).

148. See id. at $181-82$.

149. Id. at 182. Interestingly, the court alluded to the possibility of the same result occurring if then-pending legislation to create the Federal Circuit was enacted. Id. at $182 \mathrm{n} .2$.

150. Id. at 182.

151. Id.

152. Id. 
jurisdiction." 153

The House Report's explicit contrast of its statement on how Federal Circuit jurisdiction was to be construed with the decision in Coastal States evidences, at the very least, a repudiation of any idea that the Federal Circuit was to have the "issue"-type jurisdiction Coastal States held to apply to the TECA. ${ }^{154}$ And if by saying that the Federal Circuit's jurisdiction is to rise in the "same sense" as in federal question jurisdiction Congress meant statutory federal question jurisdiction, that type of jurisdiction has long been viewed to exclude the jurisdiction based on the mere presence of relevant ingredients within a case that "case" jurisdiction would allow. ${ }^{155}$

But at least one commentator has contended that this contrast with Coastal States was "ambiguous," and leaves "case" jurisdiction as a viable interpretive choice. ${ }^{156}$ The argument is that, in this contrast, Congress can only clearly be said to have eliminated the possibility of "issue" jurisdiction. Since "Congress did not specify its choice between the other two alternatives," it did not rule out "case" jurisdiction. ${ }^{157}$

The contrast to Coastal States after the "same sense" comment can only possibly be ambiguous, however, if the question of what Congress meant by "federal question jurisdiction" is ambiguous. There is a potential argument that because both constitutional and statutory federal question jurisdiction use the same "arising under" operative phrase, nothing in the use of "arising under" or reference to "federal question jurisdiction" requires that Congress meant for the Federal Circuit to exercise the equivalent of statutory federal question jurisdiction. ${ }^{158}$

Regardless of the merits of a broader, ingredient-type jurisdiction in this context, it would appear that the only way jurisdiction of this scope could be consistent with the statement in the House Report is if Congress meant constitu-

153. Since Congress did not intend to allow the TECA to exercise appellate jurisdiction over cases brought in state court in which ESA issues were raised only as defenses, the Second Circuit did not construe the TECA's jurisdiction as pure "issue jurisdiction." Id. at 183 . Additionally, even though the Second Circuit found that the TECA had jurisdiction over the appeal, it denied the motion to transfer because a notice of appeal had already been filed in that court, making a transfer unnecessary. Id. at 187 n. 12 .

154. Cf. Hale, supra note 46, at 263 ("By contrasting this case, Congress only eliminated 'issue' jurisdiction; Congress did not specify its choice between the other two alternatives."). For a discussion and repudiation of this view, see infra notes 156-65 and accompanying text.

155. See, e.g., Coastal States, 604 F.2d at 183 (contrasting traditional "arising under" and "case" jurisdiction).

156. See Hale, supra note 46 , at 263.

157. See id.

158. Cf. Dreyfuss, supra note 25 , at 31 ("If, however, Congress meant to use the constitutional definition of 'arising under' and to limit severance to statutory criteria, then the [Federal Circuit's] jurisdiction would encompass every issue in any case that raises a patent question, no matter where, or how indirectly, that question appears."). Professor Dreyfuss, however, did not specifically refer to the ambiguity of the "same sense" phrase in making this observation. 
tional federal question jurisdiction there. ${ }^{159}$ If that were what Congress meant, then "case"-type jurisdiction as defined in Coastal States would seem to be appropriate for the Federal Circuit. The question seems even further open when one considers, as the Federal Circuit argued in Aerojet, that nothing in the legislative history specifically references the well-pleaded complaint rule, the well-understood test for statutory federal question jurisdiction. ${ }^{160}$

But this alternative reading of congressional intent does not appear plausible. Of particular import is that the House Report used almost the exact words that Coastal States used to describe the option of traditional "arising under" jurisdiction. ${ }^{161}$ Given that Coastal States laid out "case" jurisdiction as distinct from "arising under" jurisdiction, Congress's replication of the "arising under" phraseology from Costal States to describe the Federal Circuit's jurisdiction is strong evidence that Congress did not intend the Federal Circuit to have "case" jurisdiction. As Coastal States itself concluded regarding the TECA's jurisdiction, Congress's use "of the phrase 'cases and controversies arising under' ... [was] strong evidence that Congress intended to borrow the body of decisional law that has developed under 28 U.S.C.A. $\$ 1331$ and other grants of jurisdiction to the district courts over cases 'arising under' various regulatory statutes," thus relying on that phrase's normal meaning in this context as referring to statutory federal question jurisdiction. ${ }^{162}$ The replication by the House Report of Costal States' language suggests that this was the meaning intended by Congress for the Federal Circuit as well.

This conclusion is further supported by Coastal States' observation that, despite the benefits of familiarity that come with the use of "arising under" jurisdiction, such jurisdiction carries the disadvantage of "scatter[ing] among the courts of appeals some ESA issues, raised by way of answer or otherwise, on which the expertise of the TECA would be helpful." "163 That real ESA issues would not necessarily create jurisdiction under the "arising under" test also

159. Or, perhaps, that this statement simply is not representative of final congressional intent. One argument to support this point would be that while the Senate Report includes much of the same discussion on jurisdiction as does the House Report, and even adds other points, it does not include the "same sense" language and the contrast to Coastal States. See, e.g., S. ReP. No. 97-275, at 18-21 (1981), reprinted in 1982 U.S.C.C.A.N. 11, 28-31 (discussing jurisdiction under newly added 28 U.S.C. $\$ 1295$ ). Nevertheless, other indicia common to both reports, such as the predicted number of cases the court would hear, militate against this argument.

160. Cf. Holmes Group, Inc. v. Vornado Air Circulation Sys., Inc., 535 U.S. 826, 833 (2002) (the phrase "arising under" is not "some neologism that might justify our adverting to the general purpose of the legislation, but rather a term familiar to all law students as invoking the well-pleaded-complaint rule").

161. Compare Coastal States, 604 F.2d at 182 ("the exclusive appellate jurisdiction of the TECA could be construed to be limited to those cases that 'arise under' the ESA in the same sense that cases are said to 'arise under' federal law for purposes of federal question jurisdiction") with H.R. REP. No. 97-312, at 40 ("[c]ases will be within [the Federal Circuit's patent jurisdiction] in the same sense that cases are said to 'arise under' federal law for purposes of federal question jurisdiction").

162. Coastal States, 604 F.2d at 183 (citing 28 U.S.C. $\$ \S 1337,1338,1339,1340$ as examples and saying "[t]he traditional meaning associated with these words could hardly have been overlooked").

163. Id. (emphasis added). 
indicates that constitutional federal question jurisdiction-which would be created by such issues-was not intended for the Federal Circuit.

Once it becomes clear that Congress was referring to statutory and not constitutional federal question jurisdiction, any ambiguity as to the intended test must disappear. There can simply be no quarrel over the fact that statutory federal question jurisdiction (including use of the well-pleaded complaint rule) is governed by the traditional 'arising under' analysis referred to in Coastal States.

Other evidence in the legislative record also demonstrates that the $\S 1331$ jurisdictional rules were intended to apply to the Federal Circuit. For example, both reports projected that the Federal Circuit would hear 400 patent appeals or less per year. ${ }^{164}$ Such projections are consistent with "a narrow view of the court's jurisdiction," ${ }^{165}$ one in which the well-pleaded complaint rule governs what cases the court can hear.

Congress's response to the fear that the Federal Circuit would appropriate too much jurisdiction for itself also points toward an intent to invoke traditional 'arising under' tests. Opponents of the court worried that "specious and peripheral patent claims" 166 could be used, through the "in part" jurisdiction of $\S 1295(a)(1)$ to create "'a locomotive that would pull all sorts of related issues into the terminal of the court's appellate jurisdiction' and allow the Federal Circuit to appropriate large elements of federal law." ${ }^{167}$ But Congress "dismissed these concerns as unwarranted, based on general federal jurisdiction

164. See S. REP. No. 97-275, at 7, 1982 U.S.C.C.A.N. at 17 ("On the basis of 1981 figures, the new court will handle ... approximately 400 patent or federal contract cases coming directly from the district courts that would have been heard by the existing circuits courts of appeals."); H.R. REP. No. 97-312, at 24 ("On a projection of 1981 figures, the new court will be handling . . approximately 350 patent or federal contract cases coming directly from the district courts that would have been heard by the regional courts of appeals.").

165. See Dreyfuss, supra note 25, at 35 n.207. But Professor Dreyfuss nevertheless saw this evidence, along with Congress's "endorse[ment of] the well-pleaded complaint rule," as simply one side of an "ambiguous" case for intent. In her view, such evidence was contradicted by the fact that "Congress heard testimony that the [Federal Circuit] should be careful not to miss 'true' patent cases through artful characterization by the parties"; testimony which expressed concern, for example, that the Federal Circuit's exclusive jurisdiction not be manipulated by parties disguising patent issues in antitrust terms. $l d$. (citations omitted). But such evidence is not nearly as specific as to the question of what jurisdictional test Congress intended as the evidence she admits points toward the well-pleaded complaint rule. And more important, the broad fear that Dreyfuss refers to has long been recognized and addressed in traditional federal question jurisdiction by the "artful pleading" doctrine. Admittedly, the doctrine's application in the federal arena appears to have been focused on attempts to avoid federal jurisdiction by mischaracterization of a federal claim as a state one-or vice versa. See, e.g., Christianson v. Colt Indus. Operating Corp., 486 U.S. 800, 821 n.2 (1988) (Stevens, J., concurring) (collecting and summarizing prior Supreme Court cases utilizing this doctrine). But in that light, Congress's concern that the Federal Circuit not miss "true" patent cases appears to reflect an intent that the artful pleading doctrine be extended to the analogous area of attempts to avoid Federal Circuit jurisdiction; it would not appear to indicate in any way that Congress did not intend traditional tests of "arising under" jurisdiction to be applied to patent claims.

166. H.R. ReP. No. 97-312, at 41.

167. Hale, supra note 46, at 239 (quoting S. REP. No. 97-275, at 19, 1982 U.S.C.C.A.N. at 29). 
principles." ${ }^{168}$ In particular, the House Report noted that such concerns were highly speculative because "one has to assume that" jurisdiction for "an appeal would be handled by the new court in a different manner than in the other circuits." 169

And the more general goals of Congress in creating the Federal Circuit do not, in themselves, necessarily indicate a congressional intent that a different jurisdictional test than that used for $\S 1331$ be applied in determining the Federal Circuit's jurisdiction. As noted above, and as was repeatedly stated in the House and Senate Reports, Congress created the Federal Circuit to promote uniformity and reduce forum shopping for favorable patent law in "patent cases" and "patent appeals." 170 Arguably, such language supports a broader jurisdictional test than was adopted in Vornado. The problem with that view is that the legislative history provides no explicit definition of what Congress considered to be a "patent case" or a "patent appeal"; this is a crucial restriction on any attempt to divine from these general statements an indication of what jurisdictional test Congress meant to use. If, for example, one determines that "patent appeal" means only an appeal arising under patent law according to the traditional tests of $\S 1331$ jurisdiction (including the well-pleaded complaint rule), then it cannot be argued that denying the Federal Circuit jurisdiction over a case without any patent claims conflicts with the congressional goal of uniformity.

Furthermore, Congress did not intend uniformity in patent law to trump all other concerns. ${ }^{171}$ As such, even if the exclusion from the Federal Circuit's

168. Id.

169. H.R. REP. No. 97-312, at 41.

170. See, e.g., Hale, supra note 46, at 238-39 ("[t]he House and Senate Committee Reports show that Congress intended to achieve uniformity by directing patent appeals, which usually are complex and time consuming, away from the regional circuits to a single appellate court") (citing H.R. REP. No. 97-312, at 18 and S. Rep. No. 97-275, at 2, 1982 U.S.C.C.A.N. at 12); see also H.R. REP. No. 97-312, at 22 (stating that such "a single court of appeals for patent cases" would "promote certainty where it is lacking to a significant degree and [would] reduce, if not eliminate, the forum-shopping that now occurs").

171. There is strong evidence that Congress never thought that the goal of uniformity was the only interest determining whether the Federal Circuit had jurisdiction. For example, if "issue" jurisdiction applied to patent issues, it would greatly reduce, if not altogether eliminate, any uniformity problems. The Federal Circuit would have jurisdiction over all patent issues, no matter when raised, and could decide them according to its uniform jurisprudence. $C f$. Coastal States Mktg., Inc. v. New Eng. Petroleum Corp., 604 F.2d 179,183 (2d Cir. 1979) ("Splitting the cases and giving the TECA only TECA 'issue' jurisdiction assures uniformity of decision-making on all ESA issues and avoids burdening the TECA with non-ESA issues, yet encounters the risk of delay and confusion inevitably associated with a system of bifurcated appeals.") (footnotes omitted). Congress's clear rejection of "issue"-type jurisdiction demonstrates its belief that uniformity interests did not justify Federal Circuit jurisdiction over all patent issues, and that Congress had limits in what it was willing to allow the Federal Circuit to do to establish patent-law uniformity.

Moreover, Congress's rejection of "case" jurisdiction, though not quite as clear as its rejection of "issue" jurisdiction, similarly shows the limits of uniformity concerns in dictating jurisdiction. Granting the Federal Circuit jurisdiction of this scope "assures uniform decision-making" in the patent law, but without the significant procedural issues involved in severing particular issues from the appeal of a 
appellate jurisdiction of patent counterclaims raises the kind of concerns for which that court was created, it is unclear whether such exclusion contravenes congressional intent when considered as a whole. As will be discussed below, there is substantial evidence that Congress intended nonfrivolous patent counterclaims to create a patent case, the appeal of which would go to the Federal Circuit. But this evidence is best explained as relating to how Congress thought the tests for determining Federal Circuit jurisdiction would be applied, not to what tests Congress thought would be used. This conclusion is reinforced by the fact that, at the time of the Federal Circuit's creation, the Supreme Court had never held that counterclaims could not arise under federal law for the purposes of $\S 1331$.

What is clear, though, is that in order to direct all "patent appeals" to the Federal Circuit, Congress enacted a statute that gave that court jurisdiction whenever a district court had jurisdiction of a case based in part on the existence of a "civil action arising under" patent law. Given this situation, it would seem that the best evidence of what test Congress intended to be used is that evidence specifically relating to the question of jurisdiction--because that then defines what Congress thought a patent appeal actually was. And as explained above, that evidence indicates that Congress thought the existence of a patent appeal would be determined the same way as for federal appeals in general.

\section{Did Congress Expect Patent Counterclaims to Create Federal Circuit} Jurisdiction?

The above discussion shows that Congress almost certainly intended the traditional tests of statutory federal-question jurisdiction-such as the wellpleaded complaint rule- to govern the Federal Circuit's patent jurisdiction. But as also stated above, there is a second important question of congressional intent to be answered here: Did Congress expect that patent counterclaims would meet those tests and create jurisdiction in the Federal Circuit? While there is scant mention of patent counterclaims in the two committee reports, the existing evidence points to an expectation that the Federal Circuit would have jurisdiction over the appeals of patent counterclaims.

Notably, the Senate Report, responding to fears that the Federal Circuit's jurisdiction could be inappropriately extended through manipulation, encouraged district courts "to use their authority under the Federal Rules of Civil Procedure[] . . to ensure the integrity of the jurisdiction of the federal court of appeals by separating final decisions on claims involving substantial antitrust

case. It also has a downside, though, in that it "withdraws from the [regional] courts of appeals many" nonpatent "issues, which may really be the dominant issues in the case, and which the [Federal Circuit] may have no interest and no special competence in deciding." Id. The congressional rejection of "case" jurisdiction similarly shows that uniformity concerns were not intended to serve as get-out-of-jail-free cards with respect to the statutory limits that Congress imposed on the Federal Circuit's jurisdiction. 
issues from trivial patent claims, counterclaims, cross-claims, or third party claims raised to manipulate appellate jurisdiction." ${ }^{172}$ While this statement shows Congress was clear that Federal Circuit jurisdiction should not be based on frivolous counterclaims and like claims, ${ }^{173}$ it says nothing, by itself, about the intended jurisdictional status of such claims if nonfrivolous. Nothing else in the main body of either report expressly answers this question. This absence of discussion relative to the comments about frivolous counterclaims and related claims indicates that Congress (1) recognized the potential that such claims might be brought; (2) recognized that they were distinct from patent claims (used here, apparently, to refer to claims brought in the complaint); and (3) did not intend to exclude them from the Federal Circuit's jurisdiction so long as they were not trivial. ${ }^{174}$

Moreover, the discussion of how sending all patent appeals to one court would "eliminate" (or words of similar scope) forum shopping based on patent law ${ }^{175}$ further supports this conclusion. ${ }^{176}$ As discussed below in Part I.E.2, excluding patent counterclaims from the Federal Circuit's jurisdiction creates patent-based forum-shopping opportunities that, while less severe than those available before 1982, are real and significant. It is difficult to imagine that Congress, assisted by the numerous interested parties that participated in the Federal Circuit's creation, would not have recognized this potential had it been clear that appeals involving patent counterclaims would not go to the Federal Circuit. $^{177}$

172. S. Rep. No. $97-275$, at 20,1982 U.S.C.C.A.N. at 30.

173. The discussion from this point on only will refer to patent counterclaims-but this Article's discussion of issues relating to patent counterclaims is generally relevant to patent cross-claims or third-party claims. These latter claims appear to be so rare, though, that it is not worthwhile to discuss them separately.

174. See Donofrio \& Donovan, supra note 46, at 1871 (stating that the "likely" implication of this statement is "that non-trivial counterclaims which are not raised to manipulate appellate jurisdiction should provide a basis for appellate jurisdiction").

175. See, e.g., H.R. REP. No. 97-312, at 23 (creation of Federal Circuit will "[remove] the incentive to forum shop").

176. Admittedly, Congress did not always use unqualified words like "prevent" or "eliminate" in describing the effect of the Federal Circuit on forum shopping. See, e.g., id. at 27 (creation of Federal Circuit "will reduce the incentive to forum-shop"); S. REP. No. 97-275, at 19, 1982 U.S.C.C.A.N. at 29 (" $[\mathrm{t}]$ his measure is intended to alleviate the serious problems of forums [sic] shopping among the regional courts of appeals on patent claims"). These more restrained references could be interpreted as indicating that the Federal Circuit would not resolve all forum-shopping problems, as some limited forum shopping with permissive counterclaims might still be available. But again, in view of the paucity of discussion of counterclaims in this report, it seems more likely that the reference was either to general forum shopping among federal courts of appeals or to forum shopping among the district courts, e.g., by intentionally filing in a district court less experienced with patent claims for some strategic benefit.

177. Other general evidence on the effect of sending all patent appeals to the Federal Circuit was to have on the RCCOAs also supports this conclusion. For example, Congress believed that "[d]irecting patent appeals to the new court will have the beneficial effect of removing these unusually complex, technically difficult, and time-consuming cases from the dockets of the regional courts of appeals." H.R. ReP. No. 97-312, at 22-23 (emphasis added). Because it is hard to see how a patent infringement 
Finally, uncontroverted testimony included in the Senate Report also points toward this conclusion-although in doing so, it raises a separate issue. A letter from William James Weller was included in one of two appendices to that report. A substantial portion of that letter discusses the possibility that the appeal of a permissive counterclaim for patent infringement filed in response to plaintiff's nonpatent claim alleging, for example, antitrust violations, could be heard by the Federal Circuit, but that the appeal of the nonpatent claim would not be. ${ }^{178}$

This statement raises the possibility that Congress thought that the presence of a patent claim would not give the Federal Circuit jurisdiction over the nonpatent claims of other parties, that the "patent appeal" to be heard by the Federal Circuit encompassed patent claims brought by all parties but not necessarily nonpatent claims of other parties. Thus, in a case like Vornado, appeals of judgments on the defendant's patent counterclaim would go to the Federal Circuit, but the appeals of the nonpatent claims brought by the plaintiff would go to the appropriate RCCOA-here the Tenth Circuit.

Such an inference, however, approaches pure speculation, as little else in the House and Senate reports would appear to support this view. Moreover, even if Congress did expect that this was how the Federal Circuit's jurisdiction would be divided, such a belief would appear to be contrary to long-standing federal precedents. ${ }^{179}$ Nevertheless, this testimony as to the Federal Circuit's jurisdiction over permissive patent counterclaims was not contradicted by anything in

claim is any less complex, difficult, or time-consuming when brought as a counterclaim, this is evidence that Congress thought the Federal Circuit would hear all appeals involving patent claims, regardless of on which side of the "v." those claims appeared.

178. S. REP. No. 97-275, at 37, 1982 U.S.C.C.A.N. at 46 (letter of William James Weller). Mr. Weller, Legislative Affairs Officer, Administrative Office of the U.S. Courts, noted that the converse situation could occur, where "one sued for patent infringement ... file[d] a permissive counterclaim against the plaintiff, which counterclaim might not involve any patent issues." Id. at 38, 1982 U.S.C.C.A.N. at 47. He went on to say that

[i]n either instance, such a counterclaim would be a separate case, tried by the same district court and at the same time solely as a matter of convenience and economy. A district court which permitted such joinder, knowing that the patent case would be appealable to the Court of Appeals for the Federal Circuit and that the other case would be appealable to the local circuit, would have no difficulty in maintaining a clear line of distinction at the trial level. That would be true whether the permissive counterclaim involving no patent issue sounded in contract, SEC law, or in true antitrust (Sherman Act; Clayton Act) law.

Id.

179. Federal caselaw has "somewhat consistently, but not at all uniformly" held that, absent severance, all claims and counterclaims are part of the same case, even if separated for trial under Rule 42(b). Gaylord A. Virden, Consolidation Under Rule 42 of the Federal Rules of Civil Procedure: The U.S. Courts of Appeals Disagree on Whether Consolidation Merges the Separate Cases and Whether the Cases Remain Separately Final for Purposes of Appeal, 141 F.R.D. 169, 180-81 (1992). Notably, the Federal Circuit has reached a similar conclusion. Atari, Inc. v. JS \& A Group, Inc., 747 F.2d 1422, 1430-31 (Fed. Cir. 1984) (stating that "[a]ction on the motion [for separate trial] is procedural, not substantive, and has no effect on jurisdiction" and concluding that "[t]here remains but one case, notwithstanding the separation"), overruled on other grounds, Nobelpharma AB v. Implant Innovations, Inc., 141 F.3d 1059 (Fed. Cir. 1998). Thus, it appears that Mr. Weller's statement was mistaken to the 
either report, further indicating that Congress thought Federal Circuit appellate jurisdiction could be based on counterclaims.

Other evidence discussed above in Part I.D. 1 regarding the test that Congress intended to be applied to determine the Federal Circuit's jurisdiction is, however, inconclusive in this context. For example, because jurisdiction over patent counterclaims is not likely to significantly increase the number of patent cases compared to those the Federal Circuit would hear if it only had appellate jurisdiction over patent complaints, congressional predictions of how many patent cases the Federal Circuit would hear are not helpful here. ${ }^{180}$ And given that the Supreme Court had never held that counterclaims could not create general federal question jurisdiction before Vornado, the "same sense" commentary only tells us the tests to be applied-not what Congress expected their result to be. On the whole, while nothing in the record evinces a direct expectation that the Federal Circuit's exclusive jurisdiction would be invoked by the presence of a patent counterclaim, the bulk of the evidence points in that direction.

\section{Vornado and Congressional Intent}

How, then, should Vornado be evaluated? In view of the analysis above regarding congressional intent that patent counterclaims invoke Federal Circuit jurisdiction, it would initially appear that the Vornado Court must have been unfaithful to that intent in holding otherwise. But closer analysis of the full implications of each relevant congressional intent-intent as to the overall jurisdictional test and intent as to patent counterclaims meeting that test-shows that these intents may, in fact, conflict.

On one hand, Congress's intent that the Federal Circuit's jurisdiction should be determined in the same way as general federal question jurisdiction seems to lead, if strictly applied, to the result reached in Vornado. It seems apparent that, as Vornado's majority opinion explained, counterclaims fail to meet the strict letter of the well-pleaded complaint rule, in that they simply do not appear in the plaintiff's complaint. ${ }^{181}$ But also important is the conclusion of seven justices in that case-the six joining the majority opinion in full, plus Justice Stevens - that each of the three policies Justice Scalia identified as traditionally supporting the well-pleaded complaint rule prevented the Federal Circuit from exercising its patent jurisdiction based solely on a patent counterclaim.

To be sure, at least one of those policies is not so clearly violated by a rule allowing counterclaim-based jurisdiction as these justices assert. In particular, allowing jurisdiction based only on patent counterclaims would not appear to

extent it claimed that appeals of patent and nonpatent issues could go to separate courts of appeals as a matter of course, as would be any congressional expectation based upon it.

180. See Mosley-Goren, supra note 12, at 40 (stating that "in the past" there have not been "an overwhelming number of cases where the Holmes Group situation, a non-patent complaint with a patent counterclaim, has arisen").

181. See supra notes $118-119$ and accompanying text. 
"radically" expand the number of cases falling within $\S 1338$, and thus within $\S 1295{ }^{182}$ Doing so would include only cases with patent claims, not cases merely involving a patent issue. ${ }^{183}$

It is, however, difficult to dispute these justices' conclusion that allowing jurisdiction based on counterclaims would contravene the settled principle of federal question jurisprudence that the plaintiff is "the master of the complaint." ${ }^{184}$ As Justice Scalia's opinion persuasively argued, prior precedents established that, as master of the complaint, the plaintiff may " "by eschewing claims based on federal law ... have the cause heard in state court." "185 In other words, the well-pleaded complaint rule preserves for the plaintiff a choice of forum that the defendant cannot divest. And as Justice Stevens observed in his Vornado concurrence, "the interest in preserving the plaintiff's choice of forum includes not only the court that will conduct the trial but the appellate court as well." 186 The rationale applies equally to the choice of appellate forum because "[a] plaintiff who has a legitimate interest in litigating in a circuit whose

182. See Vornado, 535 U.S. at 837 (Stevens, J., concurring in part and concurring in the judgment) ("I doubt that a rule that enabled the counterclaimant to be the occasional master of the appellate forum 'would radically expand' the number of cases heard by the Federal Circuit" (quoting 535 U.S. at 832 (majority opinion))). But see Mosley-Goren, supra note 12, at 40 (stating that while "in the past" there have not been "an overwhelming number of cases where the Holmes Group situation, a non-patent complaint with a patent counterclaim, has arisen .... There is some indication that the number will increase, however, as litigants consider the additional forum shopping options permitted by the Holmes Group rule and potential benefits of evading a federal forum.").

In concurring with the majority on this point, Justice Stevens instead relayed a legitimate concern that since "claims sounding in these other areas of intellectual property law are not infrequently bound up with patent counterclaims," allowing Federal Circuit jurisdiction based on patent counterclaims might result in the Federal Circuit hearing a "significant" amount of cases "that Congress specifically chose not to place within its exclusive jurisdiction." Vornado, 535 U.S. at 837. But this concern does not seem to relate to the traditional policy behind the well-pleaded complaint rule of avoiding drastic increases in the number of removable cases. Whether under Vornado's rule or Aerojet's, federal courts would have exclusive jurisdiction over all cases in which plaintiffs bring such nonpatent $\$ 1338$ claims.

183. This is not to say that expanding the Federal Circuit's jurisdiction in this manner would not be without consequences (indeed, much of this Article is premised on the negative consequences of such an expansion)-just that the actual percentage increase would likely not be classifiable as the dramatic or massive increase in removable cases that this policy aims to prevent.

184. See Vornado, 535 U.S. at 831-32 (citing Caterpillar, 482 U.S. at 392).

185. Vornado, 535 U.S. at 832 (quoting Caterpillar, 482 U.S. at 392-99). As the Caterpillar Court explained:

[T] ]he presence of a federal question ... in a defensive argument does not overcome the paramount policies embodied in the well-pleaded complaint rule-that the plaintiff is the master of the complaint, that a federal question must appear on the face of the complaint, and that the plaintiff may, by eschewing claims based on federal law, choose to have the cause heard in state court. When a plaintiff invokes a right created by a collective-bargaining agreement, the plaintiff has chosen to plead what we have held must be regarded as a federal claim, and removal is at the defendant's option. But a defendant cannot, merely by injecting a federal question into an action that asserts what is plainly a state-law claim, transform the action into one arising under federal law, thereby selecting the forum in which the claim shall be litigated.

482 U.S. at $398-99$.

186. Vornado, 535 U.S. at 837. 
precedents support its theory of the case might omit a patent claim in order to avoid review in the Federal Circuit." ${ }^{187}$ Allowing the Federal Circuit to assert jurisdiction simply because the defendant introduced a patent counterclaim into a case would defeat the interests behind this rule; if a defendant could so invoke the Federal Circuit's jurisdiction over the plaintiff's claim, "the plaintiff would be master of nothing." 188

But on the other hand, Congress's apparent expectation that patent counterclaims would be sufficient to satisfy the test for Federal Circuit jurisdiction may be evidence that the Supreme Court was wrong to make strict application of the well-pleaded complaint rule the test for Federal Circuit jurisdiction. As the Aerojet court claimed, traditional "arising under" jurisdiction-and the wellpleaded complaint rule that defines it-could be seen as focusing, at heart, on the presence of certain "claims, not theories." Circuit's jurisdiction be determined using such principles, Congress may simply have intended that the court's jurisdiction not be interpreted so broadly as to allow jurisdiction based on a patent issue, as with the "case" jurisdiction discussed above. There is arguably no need to conclude that Congress also intended that the court's jurisdiction would not be invoked by the presence of a patent counterclaim.

As one might have suspected, how patent counterclaims were historically treated with respect to the longstanding and exclusive patent jurisdiction of the federal district courts is relevant to this analysis. Strangely enough, though, both Christianson and Vornado seemed to ignore entirely the question of whether litigants had historically been able to bring patent counterclaims in state court. The Court might have believed that such a discussion was unnecessary. After all, Christianson explained that the Supreme Court had "long ago" held that the same test applied to $\S 1338$ and its precursor as applied to $\S 1331,{ }^{190}$ implying that lower courts also would have long interpreted both provisions to address federal counterclaims of all types in the same way. And since federal counterclaims have traditionally been considered not to create general federal question jurisdiction under $\S 1331$, patent and other intellectual property counterclaims should likewise not have been thought to invoke the exclusive federal jurisdiction currently set forth in $\S 1338$. If so, that would have logically meant, absent some other prohibition, that state courts would have long been considered

187. Id.

188. Caterpillar, 482 U.S. at 399; see also Vornado, 535 U.S. at 837. (Stevens, J., concurring in part and concurring in the judgment). One might argue that since the defendant is not being manipulative in introducing compulsory counterclaims, such claims should be treated differently. But this argument alone is not sufficient to distinguish such counterclaims from defenses, which can be equally compulsory in the sense that if a defendant does not introduce them, she will lose the case. Either way, a party is introducing something that it strictly is not required to-the right to bring the counterclaim at all could be waived-so as not to lose its benefits.

189. Aerojet-General Corp. v. Machine Tool Works, Oerlikon-Buehrle Ltd., 895 F.2d 736, 742 (Fed. Cir. 1990) (quoting Christianson v. Colt Indus. Operating Corp., 486 U.S. 800, 811 (1988)).

190. Christianson, 486 U.S. at 807-08 (1988). 
competent to adjudicate patent counterclaims. ${ }^{191}$

But such was not the case. In fact, state courts and commentators, apparently uniformly, concluded pre-Vornado that the exclusive jurisdiction set forth in $\S 1338$ and its precursors barred litigants from bringing either patent or copyright counterclaims in state court. ${ }^{192}$ This history casts doubt on Christianson's implication that the exclusive federal jurisdiction over patent cases was historically interpreted in precisely the same way as general federal question jurisdiction-i.e., in a manner focusing entirely on the complaint to the exclusion of any counterclaims, no matter the type. ${ }^{193}$

As for the Supreme Court's failure to discuss this history in either case, the Court necessarily gives more weight to its own precedents interpreting a federal statute than those of state courts. Thus, the Court could have just concluded that this history was irrelevant. But as explained in more detail in Part V.c, Vornado's interpretation of $\S 1338$ almost certainly allows state courts to hear patent counterclaims, in clear contrast to their historically understood role. This history surely raises the question of whether Congress intended $\S 1338$ to be interpreted so narrowly, as well as whether federal courts in the past had truly interpreted $\S 1338$ and its precursors to have the same scope as $\S 1331$.

What the discussion above should indicate, in its length if not also in its substance, is that even had the Vornado Court given more weight to broader indications of congressional intent (instead of, for example, to what "linguistic consistency" required), its result would still not necessarily have been incorrect. Although Congress almost certainly intended that the Federal Circuit have "arising under" jurisdiction over patent appeals in some sense, Congress did not clearly explain what tests were to be used to set the specifics of that jurisdiction and, importantly, did not specify that the traditionally-understood tests for "arising under" jurisdiction-under which, as the Vornado court correctly concluded, jurisdiction cannot be created by a counterclaim-were not to be used.

191. See infra note 394.

192. See Mosley-Goren, supra note 12, at 21-27 (discussing numerous cases reaching this result). This appears to have been "the common understanding" of federal courts and of the leading commentator on patent law as well. See Green v. Hendrickson Publishers, Inc., 770 N.E.2d 784, 792 (Ind. 2002) (citing Chisum on Patents \$21.02[1][e], at 21-91 n.129).

193. This is not, however, necessarily dispositive of the historical question. For one, there is some evidence that federal courts have concluded differently, as the "[o]nly ... federal appellate court decision prior to the creation of the Federal Circuit" that addressed this issue-an opinion authored by one of the Federal Circuit's most distinguished jurists-."concluded that filing a counterclaim for patent infringement . . . in state court did not alone support removal." Mosley-Goren, supra note 12, at 17 (citing Rath Packing Co. v. Becker, 530 F.2d 1295, 1303 (9th Cir. 1975) (Rich, J. sitting by designation), aff'd on other grounds sub nom., Jones v. Rath Packing Co., 430 U.S. 519 (1977)). Thus, state courts historically might have denied jurisdiction thinking that patent counterclaims did satisfy $\S 1338$, and federal courts might have denied removal thinking patent counterclaims did not. But see Schwartzkopf Dev. Corp. v. Ti-Coating, Inc., 800 F.2d 240, 244 (Fed. Cir. 1986) ("Adjudication of a patent counterclaim is the exclusive province of the federal courts. ... [They] are within the jurisdiction of the district court under $\S 1338$."). The practical effect may simply have been to force patentees sued in state court to file a separate patent infringement suit in federal court, where there would be no question as to jurisdiction. 
In the end, the Supreme Court's decision to interpret the Federal Circuit's jurisdiction more narrowly might best be justified by the "canon of construction that courts strictly construe their jurisdiction," and Congress's reliance on that canon to assure detractors that the language granting the Federal Circuit jurisdiction was "not unduly broad." could have been reached by a Court unburdened by Christianson's binding precedent; that gave adequate weight to the more closely-related evidence of congressional intent regarding patent counterclaims (as opposed to the more detailed, but less related, evidence of the test to be applied); and that accorded proper consideration to the historical exclusion of such claims from state court jurisdiction.

Perhaps more than anything else, however, it is stare decisis that makes it difficult to say that Aerojet was correct and Vornado was not. Christianson explicitly held that the Federal Circuit's patent jurisdiction extended "only" to cases in which a patent claim appeared on the face of a well-pleaded complaint. ${ }^{195}$ It was also well-established (although not mentioned in Vornado) that because Congress can revise incorrect statutory constructions by the Court, "considerations of stare decisis are at their strongest when this Court confronts its previous constructions of a statute"196 - rendering Christianson's conclusion fourteen years earlier especially binding. Since the combination of these principles left little room for the Supreme Court to apply a different jurisdictional test to $\S 1338$ (a) than to $\S 1331$, there was little sustainable argument that counterclaims might arise under one section but not the other. Thus, to the extent the Aerojet court attempted to distinguish Christianson by reference to Federal Circuit-specific policies-such as Congress's heightened desire for uniformity in patent law-it would appear to have erred. ${ }^{197}$

Of course, the Vornado majority admitted that the Supreme Court had never

194. H.R. REP. No. 97-312, at 41 .

195. Christianson, 486 U.S. at 808-09 (The Federal Circuit's $\S 1295(a)(1)$ appellate jurisdiction extends, via $\S 1338(a)$, "only to those cases in which a well-pleaded complaint establishes either that federal patent law creates the cause of action or that the plaintiff's right to relief necessarily depends on resolution of a substantial question of federal patent law, in that patent law is a necessary element of one of the well-pleaded claims.").

196. United States v. Lane, 474 U.S. 438, 460 n.1 (1986) (noting this principle "scarcely needs repeating"); see also Nigh v. Koons Buick Pontiac GMC, Inc., 319 F.3d 119, 128 (4th Cir. 2003) (Luttig, J.) ("Of course, it goes without saying, if Congress enacted into law something different from what it intended, then it can simply amend the statute to bring the statute in line with congressional intent. In this way, and in this way only, are the constitutional roles of the legislature and the courts respected.").

197. Indeed, many of the Federal-Circuit specific policies relied on in Aerojet were, independent of Christianson's holding, unpersuasive. For example, the Aerojet court pointed to the congressional goal of nationwide uniformity in patent law, and concluded that its result was supported by the canon that "a construction that undermines a statute's goal cannot stand." 895 F.2d at 745. But a conclusion that patent counterclaims cannot create federal jurisdiction does not necessarily undermine Congress's goal of uniformity in patent law. As noted earlier, Congress did not intend for the Federal Circuit to create absolute uniformity in the resolution of all patent issues. Furthermore, deference to the Federal Circuit could ensure similar treatment of patent counterclaims in RCCOAs, see infra Part III. So congressional 
decided the specific question of whether a counterclaim satisfied the wellpleaded complaint rule-even though, again, the lower courts appeared to have almost uniformly concluded that counterclaims did not. ${ }^{198}$ This left some possibility that the Supreme Court could decide that counterclaims could "arise under" both sections. But as explained above, the Vornado majority persuasively explained that counterclaims failed to meet both the letter of the rulefor example, they do not appear in the complaint-and the interests behind it. ${ }^{199}$

It is also possible that the majority's decision in Vornado was affected by the potential implications for issues of general federal question jurisdiction of a decision finding patent counterclaims to arise under $\S 1338(a)$. Some commentators have justified the narrow construction of statutory federal question jurisdiction on the ground that interpreting that jurisdiction to be as broad as constitutional federal question jurisdiction would let in too many cases. For example, it might be better for future flexibility to retain a broad conception of Article III jurisdiction and a narrower construction of statutory jurisdiction. ${ }^{200}$

But such concerns would seem to be less relevant to patent counterclaims given that (1) the countervailing interest in patent uniformity would counsel in favor of Federal Circuit jurisdiction; (2) as noted above, the contrary rule would not "radically" expand the number of cases falling within $\S 1338$; and (3) even

goals are not necessarily thwarted by Vornado's conclusion-though given the general adherence to the rule of no deference, see infra Part II, those goals may be less likely to be achieved.

In addition, the Federal Circuit's reliance on cases where courts had exercised jurisdiction over counterclaims alone was, as Justice Scalia pointed out, irrelevant to the question presented. Those cases dealt with the ability of a district court to "retain jurisdiction over a counterclaim if the complaint (or a claim therein) is dismissed or if a jurisdictional defect in the complaint is identified." Vornado, 535 U.S. at 834 n.4. They "do not even mention the well-pleaded-complaint rule that the statutory phrase 'arising under' invokes." $I d$. The motivation for such jurisdiction-largely as a matter of judicial economywould appear to be distinguishable from the policies behind the well-pleaded complaint rule. Since, for example, the defendant with a compulsory federal counterclaim could re-file against the plaintiff and create jurisdiction (or withdraw his claim since it would no longer be compulsory), there appears to be little reason not to simply keep the case in the court that has become familiar with it.

The one Federal Circuit-specific concern that seems to have substantial weight in light of Christianson is that the state/federal concerns behind the well-pleaded complaint rule are not present when deciding which of two federal appellate courts should hear an appeal. Aerojet, 895 F.2d at 743-44. But the Aerojet court never confronts the fact that because its jurisdiction necessarily depends, at least in part, on the district court having had jurisdiction under $\$ 1338$, expansion of its exclusive jurisdiction to include patent counterclaims necessarily must expand the exclusive jurisdiction of the district courts as well. And that latter expansion certainly would implicate the state/federal concerns behind the wellpleaded complaint rule. See, e.g., Donofrio \& Donovan, supra note 46, at 1850 ("Congress defined the boundary line between the regional circuit courts and the Federal Circuit in patent cases by reference to 28 U.S.C. $s$ 1338, an existing statute that specifically grants jurisdiction to the trial courts. Thus, determining the scope of the Federal Circuit's patent jurisdiction necessarily requires interpreting the jurisdictional basis of the trial court over the action.") (footnotes omitted).

198. See Vornado, 535 U.S. at 831 (collecting lower court cases to that effect).

199. See supra Part I.c.2.

200. See Chemerinsky, supra note 51, at 268 (citing Paul J. Mishkin, The Federal "Question" in the District Courts, 53 Colum. L. Rev. 157, 162-63 (1953)). Such an interpretation is not likely based on legislative intent, however, as what meager evidence we have of that intent points toward an interpretation coincident with Article III boundaries. See, e.g., Barry Friedman, A Different Dialogue: The Supreme Court, Congress and Federal Jurisdiction, 85 Nw. U. L. REv. 1, 21 (1990). 
though this broader construction takes more cases away from state courts, this arguably is less of a concern given that $\S 1338$ (a) is a grant of exclusive jurisdiction to federal courts, not of concurrent jurisdiction like $\S 1331$, and thus appears to define a legal area where state courts have no role. ${ }^{201}$ Again, however, the Vornado majority may have felt hemmed in by Christianson; given the explicit link Christianson makes between the tests for $\S 1338$ (a) and $\S 1331$ jurisdiction, it is difficult to see how the Court could have interpreted counterclaims to arise under only one of those sections without overruling its previous decision.

\section{Problems with Justice Ginsburg's Proposed Rule}

In her separate opinion, Justice Ginsburg proposed a jurisdictional rule different from any of the ones mentioned above. But her rule-in which the Federal Circuit would have exclusive appellate jurisdiction over cases in which a compulsory patent counterclaim was "actually adjudicated" below ${ }^{202}$-is not supported by any acceptable interpretation of the relevant jurisdictional statutes.

The most favorable reading of Justice Ginsburg's opinion is that it only interprets $\S 1295(a)(1)$, and not $\S 1338(a)$. In other words, $\S 1338(a)$ original jurisdiction would still be set at the beginning of the case by the well-pleaded complaint rule, but $\S 1295(a)(1)$ appellate jurisdiction would encompass cases in which a patent counterclaim was "actually adjudicated." 203 Even then, it is

201. This would accord with the historical interpretation that state courts have no authority to adjudicate patent claims. See supra note 192 and accompanying text.

202. Vornado, 535 U.S. at 840 (Ginsburg, J., concurring in the judgment).

203. The other apparent interpretation of Justice Ginsburg's opinion is that it only changes the interpretation of $\S 1338$, not $\S 1295$. This interpretation would at least avoid textual inconsistency with $\S 1295$. That is, under this interpretation $\S 1338$ would cover any case in which a patent claim is not just present, but is "actually adjudicated," leading to a clean reading of $\S 1295$ as giving the Federal Circuit jurisdiction in such cases (because the district court's jurisdiction "was based" on $\S 1338$ ).

But such an interpretation seems much less likely. First, Justice Ginsburg explicitly claimed that the "question now before this Court bears not at all on a plaintiff's choice of trial forum." Vornado, 535 U.S. at 840 . Given that the jurisdiction of the trial forum is the express concern of $\S 1338$, it seems doubtful that she meant to change that provision's interpretation. Furthermore, a rule that would determine a trial court's jurisdiction only after the case has been decided violates long-held notions of that concept; jurisdiction has been traditionally understood as the "authority to decide the case either way." The Fair v. Kohler Die \& Specialty Co., 228 U.S. 22, 25 (1913) (Holmes J.); see also Steel Co. v. Citizens for a Better Env't, 523 U.S. 83, 94 (1998) ("Without jurisdiction, the court cannot proceed at all in any cause ...."') (quoting Ex parte McCardle, 7 Wall. 506, 514, 19 L. Ed. 264 (1868)). As such, it is entirely unclear how a court's jurisdiction could be decided at the end of a case.

Such an interpretation also would be doctrinally unclear. Justice Ginsburg does not address, for example, how such a rule would affect federal jurisdiction under $\$ 1338$ (a) over a counterclaim made in state court-removal is typically exercised or waived well before the state case is actually adjudicated. See, e.g., 28 U.S.C. $\$ 1446$ (b) (2000) (requiring the defendant to file a notice of removal within thirty days of being served with the complaint); CHEMERINSKY, supra note 51, at 1348 ("The rationale for this waiver rule is that a defendant should not be able to try part of the case in state court and then, perhaps after some unfavorable rulings, seek a new forum."). Whether a claim has been "actually adjudicated," however, logically cannot be decided until after it has been so adjudicated. Moreover, the Federal Circuit cannot exercise ordinary appellate jurisdiction over a state court. See id. at 862 n.1 ("federal courts lack jurisdiction to review state court decisions" on direct appeal) (citing Rooker v. Fidelity Trust 
not entirely clear whether Justice Ginsburg thinks that patent counterclaims can create $\S 1338$ jurisdiction in the district court, but it seems safe to assume that she does. ${ }^{204}$

More important, however, is that Justice Ginsburg's proposed rule for determining the Federal Circuit's patent jurisdiction is seriously flawed. Not only is it unfaithful to the very congressional intent it intends to effectuate, it also appears to disregard on-point precedent and the statutory text itself.

First, reference to the text of $\S 1295(a)(1)$ shows that the core test of jurisdiction under that section is whether the district court's jurisdiction "was based, in whole or in part, on section 1338 ...." Nothing in $\S 1295(\mathrm{a})(1)$ refers to what happens after the district court's jurisdiction over a case was established.

Second, Justice Ginsburg's proposed rule is in direct conflict with Congress's desire to tie the Federal Circuit's $\S 1295$ (a)(1) jurisdiction directly to a district court's $\S 1338$ jurisdiction in all cases. Congress made two observations of particular relevance here. The first was that the "statutory language in question specifically requires that the district court have jurisdiction under 28 U.S.C. $\S 1338 . "{ }^{205}$ And the second was that $\S 1295(a)(1)$ "gives the [Federal Circuit] jurisdiction of any appeal in which the trial court jurisdiction was based, in whole or in part, on section 1338 ..."206 Justice Ginsburg, however, would impose a limitation on the Federal Circuit's jurisdiction that Congress did not intend. Her rule (based on its most favorable interpretation) would exclude some appeals in which the district court's jurisdiction was based on $\S 1338$ because a patent claim was presented on the face of the well-pleaded complaintthere being no plausible reading of these statutes that could limit her rule to counterclaims alone-if, by the time of appeal, that patent claim had not been "actually adjudicated." This directly conflicts with Congress's desire that the Federal Circuit have exclusive jurisdiction over any patent appeal in which

Co., 263 U.S. 413, 416 (1923)). Since $\S 1338$ (a) counterclaim jurisdiction would not be determined until or near the conclusion of a case, this interpretation of Justice Ginsburg's rule would potentially give the Federal Circuit appellate jurisdiction over patent counterclaims filed in federal court, but not in state court-an unusual circumstance given Congress's apparent desire to give the Federal Circuit appellate jurisdiction over all patent counterclaims.

But in any event, either interpretation seems to reflect a belief that $\S 1295(\mathrm{a})(1)$ should not include cases where a patent counterclaim was present but not actually adjudicated, which implicates many of the concerns discussed in this subpart.

204. This question is important in that it determines the textual legitimacy of Justice Ginsburg's interpretation of $\S 1295$. If district courts have $\$ 1338$ jurisdiction over patent counterclaims when filed, then her rule that the Federal Circuit could only hear those claims if "actually adjudicated" has some plausibility as a narrow interpretation of $\S 1295$. But if patent counterclaims did not create $\S 1338$ jurisdiction when filed but did create $\S 1295$ jurisdiction if "actually adjudicated," Ginsburg's rule would seem textually illegitimate. Section 1295 clearly requires that the district court have had $\$ 1338$ jurisdiction over the case.

205. H.R. REP. No. 97-312, at 41 .

206. Id. (emphases added). 
$\S 1338$ jurisdiction existed in the district court. ${ }^{207}$

What is worse, the Court in Christianson had already addressed and rejected the same test that Justice Ginsburg proposed in Vornado. The Christianson Court concluded that even though congressional goals might "be better served if the Federal Circuit's jurisdiction were to be fixed 'by reference to the case actually litigated," Congress "determined the relevant focus . . . when it granted jurisdiction to the Federal Circuit over 'an appeal from . . . a district court . . if the jurisdiction of that court was based ... on section 1338."208 The Christianson Court backed up its conclusion here by reference to the legislative history, stating that cases were to "arise under" the Federal Circuit's patent jurisdiction in the "same sense" as for traditional "arising under" jurisdiction. ${ }^{209}$ But a jurisdictional test based on what claims were "actually adjudicated" is entirely different from how general federal question jurisdiction is determined.

Finally, Justice Ginsburg does not address the serious problems that arise from having appellate jurisdiction turn on what was "actually adjudicated" at trial. Justice Stevens sagely noted that a test of appellate jurisdiction based on what was "actually adjudicated" bears the risk that an appeal taken at one point in a case would go to one circuit, and an appeal taken later in the case would go to another. ${ }^{210}$ This concern is borne out by Justice Ginsburg's opinion itself. She concluded that jurisdiction for the Vornado appeal was properly in the Tenth Circuit because the patent counterclaim in the case had not been "actually adjudicated." But if somehow the patent claim in the case was later addressed and decided by the district court, appellate jurisdiction would shift to the Federal Circuit, and its law-rather than the Tenth Circuit's--would govern the issues in that case.

The wisdom of Justice Ginsburg's rule, then, would appear to depend on an assumption that the law applied in the case would not change if appellate jurisdiction shifted from an RCCOA to the Federal Circuit. But Justice Ginsburg either failed to understand, or simply dismissed, the reality that the Federal Circuit does not always apply the law of a particular regional circuit to any issue produced by claims that do not "arise under" patent law. ${ }^{211}$ In a world in

207. See also id. at 23-24 (stating that "if the district court has jurisdiction over the case under 28 U.S.C. $\$ 1338(a)$, on the ground that the case arises under the patent law, the appeal in that case[] will go to the new appellate court") (emphases added); S. REP. No. 97-275, at 20, 1982 U.S.C.C.A.N. at 30 (1295(a)(1) "gives the Court of Appeals for the Federal Circuit jurisdiction of any appeal in which district court jurisdiction was based, in whole or in part, on section 1338 of title 28").

208. Christianson, 486 U.S. at 813-14.

209. Id. at 814 (quoting H.R. REP. No. 97-312, at 41 ).

210. See Vornado, 535 U.S. at 839 n.3 ("fixing appellate jurisdiction with respect to the complaint also ensures that a case that has been appealed and remanded will return to the same appellate court if there is a subsequent appeal") (citing Kennedy v. Wright, 851 F.2d 963 (7th Cir. 1988) (Easterbrook, J.)).

211. See infra notes 344-345, 379-381, as well as accompanying text. It seems unlikely, however, that Justice Ginsburg's opinion was based on her failure to comprehend this reality, given that both parties argued in their briefs to the Supreme Court that the other side's position was based on an attempt 
which the Federal Circuit chooses to apply its own law to aspects of claims not arising under patent law, such problems make Justice Ginsburg's rule unwise.

\section{E. SUMMARY}

As shown above, Congress created the Federal Circuit in response to serious problems caused by the RCCOAs' inconsistent adjudication of patent cases. Congress's primary goal in creating the Federal Circuit was to bring uniformity to patent case law, which Congress believed would improve the administration of patent law and prevent patent-based forum shopping. Concededly, Congress intended for the Federal Circuit's jurisdiction to be determined using principles of traditional "arising under" jurisdiction. A strict application of those principles would support the result in Vornado. But the evidence of congressional intent as to the Federal Circuit's jurisdiction over patent counterclaims specifically, as well as the history of exclusive federal adjudication of patent claims generally, make it seem unlikely that Congress intended the application of such principles to prevent the Federal Circuit from asserting jurisdiction over patent counterclaims. Congress simply may not have recognized that strict application of the traditional "arising under" rules would prohibit jurisdiction based on counterclaims. Or perhaps Congress only intended to prohibit jurisdiction based on mere issues-a cornerstone of $\S 1331$ jurisdiction-while allowing the Federal Circuit a broader reach in deciding what claims created $\S 1338$ jurisdiction. Nevertheless, Christianson essentially bound the Supreme Court to a strict construction of the well-pleaded complaint rule when determining the Federal Circuit's patent jurisdiction. Given the strength of stare decisis when dealing with statutory construction issues, it is difficult to say that Vornado was incorrectly decided.

\section{Problems if Current Choice-of-Law Rules Are Applied}

Depending, perhaps, on one's jurisprudential preferences, the Vornado Court may or may not have reached the correct result. But the same stare decisis principles that reinforce the Supreme Court's decision in Vornado also make it exceedingly unlikely that, absent congressional amendment of the relevant jurisdictional statutes, the Court will revisit that interpretation. Some practical consequences, though, are clear-most notably, Vornado will result in the RCCOAs hearing appeals involving patent counterclaims. In fact, in just the first few months after Vornado was decided at least three appeals in the Federal Circuit were transferred to RCCOAs or dismissed based on the new jurisdictional rule. ${ }^{212}$ It thus is necessary to analyze what problems this shift in

to have the appeal heard by a circuit with more favorable trade-dress law. See supra note 115 and accompanying text.

212. See Telcomm Tech. Services, Inc. v. Siemens Rolm Commun., Inc., 295 F.3d 1249 (Fed. Cir. 2002) (transferring case to the Eleventh Circuit based on Vornado); Medigene AG v. Loyola Univ. of Chi., 41 Fed. Appx. 450, 450 (Fed. Cir. 2002) (non-precedential) (transferring case to the Seventh 
appellate forum may produce. Part II.A explains the history of the rule of no deference, what it requires, and its traditional justifications. Part II.B then demonstrates the problems that will occur if other federal courts adhere to that rule when deciding patent issues produced by patent counterclaims.

\section{A. CURRENT RULE OF NO DEFERENCE TO A COORDINATE FEDERAL COURT'S PRECEDENT}

The opinion for the Court in Vornado left unanswered the question of what body of patent decisions RCCOAs should apply to any patent counterclaims they hear, saying only that "[n]ot all cases involving a patent claim fall within the Federal Circuit's jurisdiction." ${ }^{213}$ Justice Stevens's separate opinion, though, suggests that RCCOAs, in hearing patent counterclaims, will be able to develop their own patent jurisprudence independent of the Federal Circuit's. Because Vornado only more firmly establishes that the Federal Circuit's exclusive jurisdiction does not extend to all cases raising patent issues, Justice Stevens concluded that "[n]ecessarily, therefore, other circuits will have some role to play in the development of this area of the law." 214

Justice Stevens does not explain how this conclusion follows as of necessity from the fact that RCCOAs can hear some cases with patent issues. But the idea does correspond with what might be called the rule of no deference-the general rule in federal law that "no court of appeals is bound to respect the decision of another on an issue of federal law." 215 In other words, while RCCOAs may treat the decisions of coordinate courts of appeals as persuasive, they do not defer to them. ${ }^{216}$

Prior to 1891, when the Evarts Act $^{217}$ - the basis of the modern federal system of appellate courts-was passed, the issue of different interpretations of federal law created by intermediate appellate courts was not a large concern, as "appellate review in the federal systems was basically limited to review by the Supreme Court." 218 But the Evarts Act drastically changed this system by

Circuit based on Vornado); Mattel, Inc. v. Lehman, 49 Fed. Appx. 889, 890 (Fed. Cir 2002) (nonprecedential) (appeal dismissed pursuant to Vornado on the ground that, even assuming that patent counterclaims had been raised present, no patent claim was presented in the complaint).

213. 535 U.S. at 834.

214. Id. at 839 (Stevens, J., concurring in part and concurring in the judgment).

215. Richard L. Marcus, Conflicts Among Circuits and Transfers Within the Federal Judicial System, 93 YALE L.J. 677, 686-87 (1984) .

216. See, e.g., Nixon v. Kent County, 76 F.3d 1381, 1388 (6th Cir. 1996) ("Although we do not take lightly disagreement with the views of our sister circuits, we are not constrained to follow them if, in our opinion, they are based upon an incomplete or incorrect analysis."); Atchison, Topeka \& Santa Fe Ry. v. Pena, 44 F.3d 437, 443 (7th Cir. 1994) ("[W]hile we carefully consider the opinions of our sister circuits, we certainly do not defer to them."); United States v. Diamond, 430 F.2d 688, 692 (5th Cir. 1970) ("[e]ven if authority from our respected sister Circuit were binding rather than persuasive ..."); see also Marcus, supra note 215, at 687 (distinguishing the fact that "[c]ourts of appeals often endorse ... uniformity [in federal law] as a matter of policy and strive to avoid conflicts" from "real deference--unexamined adherence to the dècisions of another circuit").

217. The Circuit Courts of Appeals Act of 1891, ch. 517, 26 Stat. 826.

218. Marcus, supra note 215, at 686; see generally Russell R. WheEler \& CYNTHIA HaRRison, Creating the Federal Judicial System 9, 12, 16, 18 (2d ed. 1994), available at http://www.fjc.gov/public/ 
creating an appellate court for each circuit with the authority to review decisions of the district courts within that circuit. ${ }^{219}$ This division, and the application of the rule of no deference in each RCCOA, "allows each circuit to interpret federal law independently of the other circuits," 220 with the Supreme Court retaining the ability to resolve on writ of certiorari any intercircuit conflicts. $^{221}$

The rule of no deference has a "long history"222 — as the Eleventh Circuit has explained, "[i]t is common knowledge that the decisions of the court of appeals for one circuit are not binding upon the courts of appeals for other circuits.",223 In fact, it appears that "not long" after the Evarts Act, circuit courts of appeals were proclaiming that "it was their duty to independently examine questions of federal law even if the precise point had already been decided by another circuit court of appeals."224

Although there have been some exceptions among circuits and in specific situations, ${ }^{225}$ more recent cases have reaffirmed the rule of no deference as a general principle. In a 1993 case, for example, the Second Circuit stated that "until the Supreme Court speaks, the federal circuit courts are under duties to arrive at their own determinations of the merits of federal questions presented to them; 'if a federal court simply accepts the interpretation of another circuit without [independently] addressing the merits, it is not doing its job." "226 The D.C. Circuit has observed that "the federal courts have not only the power but

pdf.nsf/lookup/creating.pdf/ (discussing the development of the federal judicial system from the Founding to the Evarts Act and surrounding debates) (last visited Jan. 17, 2004). According to Professor Marcus, "Technically, the [then-existing] circuit courts had jurisdiction to review decisions of the district courts in certain matters, but there was no trace of a system of intermediate appellate review between the trial courts (which included the circuit courts) and the Supreme Court." Id. at 686 n.57. Under this system, the pressing problem was not "conflicting interpretations" of federal law, but rather "the absence of effective appellate supervision [, which] created arbitrary and disparate results." Id. at 686 n.58. In the end, "the burden eventually placed on the Supreme Court's caseload necessitated changes," resulting in the passage of the Evarts Act. Id. at 686.

219. See Joan E. Schaffner, Federal Circuit "Choice of Law": Erie Through the Looking Glass, 81 Iowa L. Rev. 1173, 1175 (1996). Interestingly, the legislators that passed the Evarts Act were "well aware" that "it did not provide for intercircuit consistency." Joseph F. Weis, Jr., Disconnecting the Overloaded Circuits-A Plug for a Unified Court of Appeals, 39 ST. Louls U. L.J. 455, 459 (1995). But after a quarter-century of debating a new appellate structure for the federal courts, "they were ready to accept any kind of a compromise, even if the final product contained serious flaws." Id.

220. See Schaffner, supra note 219 , at 1175.

221. See Marcus, supra note 215 , at 687.

222. See Schaffner, supra note 219 , at 1195 n.148 (explaining that despite the Second Circuit's deference to the local circuit on issues of state law, see infra Part III.c.2, "if [an] issue raises federal law questions, the court has a long history of exercising independent judgment ...").

223. Bonner v. City of Prichard, 661 F.2d 1206, 1209 (11th Cir. 1981) (en banc) (quoting 1B J. Moore, Federal Practice P 04.02(1) (1980)).

224. Weis, supra note 219, at 459 (citing Heckendorn v. United States, 162 F. 141, 143 (7th Cir. 1908)).

225. See, e.g., infra Part III.c.

226. Menowitz v. Brown, 991 F.2d 36, 40 (2d Cir. 1993) (per curiam) (quoting In re Korean Air Lines Disaster of Sept. 1, 1983, 829 F.2d 1171, 1175 (D.C. Cir. 1987), aff'd sub. nom, Chan v. Korean Airlines, 490 U.S. 122 (1989)). 
the duty to decide [issues of federal law] correctly. There is no room in the federal system of review for rote acceptance of the decision of a court outside the chain of direct review."227 More pointedly, the D.C. Circuit has proclaimed that the idea that a court "would defer on stare decisis grounds to a decision by a co-ordinate court with which [it] disagreed is unworthy of comment."228

The rule has at least two traditional justifications. But before those are discussed, it should be made clear that one seemingly obvious reason for the rule is not really a justification at all. In particular, one might think that a justification for the rule of no deference is that the precedents of courts outside of a court's appellate hierarchy are not binding. For example, because the Tenth Circuit cannot review decisions of the Sixth Circuit, the Sixth Circuit is not bound by Tenth Circuit precedents.

This is, of course, correct. But while this reason is sufficient to explain why a court does not have to defer, it does not explain why it should not defer. In other words, that a case was decided by a court outside of the relevant vertical hierarchy is sufficient to explain why that court's decision is not inherently binding. It is not by itself, however, a satisfactory reason why a coordinate court would not choose to defer to the first court's earlier interpretation of federal law-especially in view of the undeniable interest in the uniform interpretation of federal law. ${ }^{229}$

That being said, the first traditional justification for the rule of no deference is an idea that Professor Marcus-who is quoted in several cases on this issue and cited in even more ${ }^{230}$ - has called the "principle of competence" of federal courts with respect to federal law. ${ }^{231}$ This principle "follows naturally from the structure of appellate review established by the Evarts Act."232 By setting up courts of appeals independent of each other and "subject only to review by the Supreme Court," the Evarts Act system "assumes that the courts of appeals are

227. In re Korean Air Lines Disaster, 829 F.2d at 1175 (quoting Marcus, supra note 215, at 679, 702).

228. Consumers Union of the United States, Inc. v. Consumer Prod. Safety Comm'n, 590 F.2d 1209, 1217 (D.C. Cir. 1978), rev'd on other grounds sub nom., GTE Sylvania, Inc. v. Consumers Union of the United States, 445 U.S. 375 (1980) (citing, inter alia, City Stores Co. v. Lerner Shops, Inc., 410 F.2d 1010,1014 (1969) ("[d]ecisions of district courts and other courts of appeal are, of course, not binding on us and are looked to only for their persuasive effect"; "[i]f they fail to persuade by the use of sound and logical reasoning, they will not be followed, no matter how great their number")).

229. See, e.g., Weis, supra note 219 , at 458 (remarking that "[a]s has frequently been said, the importance of uniformity in the application of law is an important part of our jurisprudence" and quoting Judge Henry J. Friendly's observation that uniformity is "the most basic principle of jurisprudence").

230. See, e.g., supra notes 226-27. As exemplified by Menowitz, many of the quotes of Professor Marcus on this issue arise from quotes of then-Judge Ruth Bader Ginsburg's adoption of his logic in Korean Air Lines Disaster. See, e.g., In re Baseball Bat Antitrust Litig., 75 F. Supp. 2d 1189, 1200 (D. Kan. 1999); In re NORPLANT Contraceptive Prod. Liab. Litig., 878 F. Supp. 972, 975 (E.D. Tex. 1995); In re United Mine Workers of Am. Employee Ben. Plans Litig., 854 F. Supp. 914, 918 (D.D.C. 1994).

231. Marcus, supra note 215 , at 702 .

232. Id. at 702-03. 
competent to decide questions of federal law correctly and mandates that they do so ...." ${ }^{233}$ As Marcus concluded in explaining why an Erie-based choice-oflaw rule was not applicable to a choice of which regional circuit's law to apply to issues of federal law after a transfer between circuits: "[T]he most significant choice-of-law difference between issues of state law and issues of federal law is that [federal courts] lack competence to decide the former and are presumptively competent to decide the latter."234

The other traditional justification for the rule of no deference, and in particular the different interpretations of federal law that it allows, is the "percolation process." ${ }^{235}$ Under this theory, the ability of circuit courts of appeals to independently interpret federal law is viewed "as a means of providing more independent review of legal issues and experimentation with varying legal rules."236 Proponents of percolation argue that the Supreme Court is aided by the "divergent interpretations of federal law" that the rule of no deference allows, adding that these differences "fully air issues before the Court is called upon to decide them," or even that "regional disparities in interpreting federal law are desirable." ${ }^{237}$ At base, the theory seems to rest on the view that the expression of differing interpretations of federal law "will ultimately lead to the 'right' result, either by consensus [among the courts of appeals] or by a ruling of the Supreme Court." ${ }^{238}$

Regardless of the justifications, the rule of no deference would require that RCCOAs independently decide issues of patent law when adjudicating patent claims. There is, however, some very limited history of RCCOAs giving special

233. Id. at 702 .

234. Id.

235. See Weis, supra note 219 , at 461 (noting that the theory "has the support of some Supreme Court justices, judges, and academics").

236. Schaffner, supra note 219 , at 1175.

237. Marcus, supra note 215, at 690 (citations omitted); see also Hruska Commission Report, supra note 30, at 235. The Hruska Commission Report concluded, in analyzing the merits of specialized courts generally, that:

[G]iving a national court exclusive jurisdiction over appeals in a category of cases now heard by the circuit courts would tend to dilute or eliminate regional influence in the decision of those cases. Our nation is not yet so homogenous that the diversity of our people cannot be reflected to some advantage in the decisions of the regional courts.

Id.

238. Weis, supra note 219, at 461; see also Hart v. Massanari, 266 F.3d 1155, 1173 (9th Cir. 2001) ("This ability to develop different interpretations of the law among the circuits is considered a strength of our system. It allows experimentation with different approaches to the same legal problem, so that when the Supreme Court eventually reviews the issue it has the benefit of 'percolation' within the lower courts.") (citing Samuel Estreicher \& John E. Sexton, A Managerial Theory of the Supreme Court's Responsibilities: An Empirical Study, 59 N.Y.U. L. Rev. 681, 716 (1984)). Judge Weis, who is quite critical of the merits of this theory and of the benefits of intercircuit conflicts generally, has posited that the development of percolation as a benefit may have been "because of necessity, or in an attempt to put the best face possible on an undesirable practice." Weis, supra note 216 , at 461 . He questions the idea that there is one "right answer," and observes that "[p]ercolation may be a very profound process for its partisans, but most litigants would label it pernicious." Id. at 462 . Weis concludes that the "questionable benefits of percolation are outweighed by its objectionable features." Id. at 463 . 
weight to the views of the relevant specialized court on patent issues-though, in the end, they still refused to consider them binding. The D.C. Circuit, for example, once concluded with regard to one of the Federal Circuit's predecessor courts that "[w]e recognize the special competence of [the CCPA] to deal with matters relating to patents and as to technical or highly specialized patent matters, we would accord substantial weight to its views." ${ }^{239}$ In contrast, the views of the CCPA outside of its area of expertise "are those of a coordinate appellate court ...; they are persuasive and entitled to deference, but are not authoritatively binding." ${ }^{240}$ Unfortunately, that circuit apparently reversed itself only nine years later, holding that even in a patent case, " $[\mathrm{w}] \mathrm{e}$ are of course not bound to do more than accord to the holding of the Court of Customs and Patent Appeals the degree of deference due a coordinate court. ${ }^{241}$

Another such example is the Seventh Circuit's decision in Christianson on remand from the Supreme Court. ${ }^{242}$ There, the Seventh Circuit held that, although it was not bound by the vacated decision of the Federal Circuit on the issues presented by the case, "the comprehensive nature of the decision, along with the recognition that Congress created the Federal Circuit with the goal of achieving uniformity and coherence in the patent laws ... counsel us against straying far from the court's thorough analysis of the difficult issues presented by this case." ${ }^{243}$ But one cannot rely on RCCOAs having the benefit of Federal Circuit analysis of the particular facts in a case very often, especially in view of the clear jurisdictional rule Vornado laid down. In this regard, the Seventh Circuit's decision here is more akin to the requirements of law-of-the-case doctrine than it is related to the broader question of intercircuit deference. ${ }^{244}$

\section{B. PROBLEMS IF THE RULE OF NO DEFERENCE IS FOLLOWED}

These limited examples of RCCOAs according substantial weight to the precedents of the "patent courts" only exemplify the unwillingness of RCCOAs to depart fully from the rule of no deference-even when they recognize the strong policy reasons for doing so. Particularly in view of Justice Stevens's

239. Watson v. Allen, 254 F.2d 342, 347 (D.C. Cir. 1958).

240. Id.

241. Eli Lilly \& Co. v. Brenner, 375 F.2d 599, 601 (D.C. Cir. 1967).

242. Christianson v. Colt Indus. Operating Corp., 870 F.2d 1292 (7th Cir. 1989), on remand from 486 U.S. 800 (1988).

243. 870 F.2d at $1298-99$.

244. The question of intercircuit deference is distinct from that of the law of the case, in that the latter unsurprisingly requires that the same dispute be involved. See Int'l Union of Painters \& Allied Trades Local 970 \& 1144 v. N.L.R.B., 309 F.3d 1, 6 (D.C. Cir. 2002) (comparing Korean Air Lines Disaster, see supra note 227 and accompanying text, with Hill v. Henderson, 195 F.3d 671, 678 (D.C. Cir. 1999) (addressing situation where the decision of an out-of-circuit "court of coordinate status is entitled to be considered "law of the case"')). More particularly, the law-of-the-case doctrine "posits that when a court decides upon a rule of law, that decision should continue to govern the same issues in subsequent stages in the same case." Christianson, 486 U.S. at 816 . This doctrine was not available on remand to the Seventh Circuit in Christianson because the Supreme Court vacated the Federal Circuit's earlier opinion for lack of jurisdiction. Christianson, 870 F.2d at 1298. 
comments in Vornado, it seems quite likely that RCCOAs presented with patent counterclaims will not consider themselves bound by Federal Circuit precedents. In other words, RCCOAs in this situation will consider themselves free to independently interpret patent law, characterizing the Federal Circuit's patent jurisprudence as only persuasive authority. This is, of course, a significant distinction. Deference lies in "unexamined adherence to the decisions of another" court in at least some classifiable situations. ${ }^{245}$ Only when Federal Circuit precedents would not otherwise persuade an RCCOA to reach the same result does deference have any real effect.

The independent development of patent jurisprudence by RCCOAs, however, would conflict with the primary goals behind the Federal Circuit. For one thing, it would contravene the key congressional goal of uniformity in patent jurisprudence, which motivated the creation of the Federal Circuit. As noted above, an important reason for the creation of the Federal Circuit was that RCCOAs had, through their previous ability to adjudicate appeals involving patent claims contrary to how those same appeals would be decided in other circuits, severalized patent jurisprudence to an extent that Congress found detrimental to national interests. Application of the rule of no deference in the wake of Vornado allows intercircuit conflicts in patent law to arise once more, even though Congress intended the Federal Circuit's exclusive jurisdiction over patent appeals to eliminate precisely such conflicts. ${ }^{246}$

Application of the rule of no deference also would significantly frustrate Congress's goal of preventing patent-based forum shopping. Admittedly, such concerns are necessarily less at stake when discussing the ability of parties to selectively file counterclaims rather than complaints. But it is quite foreseeable, for example, that patentees already involved in litigation against their competitors for other reasons may attempt to file permissive counterclaims to take advantage of an RCCOA's more favorable patent jurisprudence. What is more, application of the rule of no deference in an unaltered post-Vornado world would allow an opportunistic patent infringer to file before the patentee in the infringer's chosen circuit on a nonpatent claim that would force a compulsory counterclaim of patent infringement from the patentee, thereby subjecting that patent claim to a jurisprudence more favorable to the infringer. ${ }^{247}$ In either case,

245. See Marcus, supra note 215 , at 687 ("[R]eal deference-unexamined adherence to the decisions of another circuit-is no substitute for the independent decisionmaking by each court of appeals that is inherent in the system created by the Evarts Act.").

246. See supra notes $25-41$ and accompanying text.

247. This situation is more possible than one might initially think. For example, imagine that a patentee, believing it has both patent and closely connected federal trade-dress rights enforceable against a California competitor, sends out a cease-and-desist letter regarding those rights. Assuming the requirements for doing so were satisfied, see, e.g., Cordis Corp. v Medtronic, Inc., 835 F.2d 859, 862 (Fed. Cir. 1987), the competitor could file a declaratory judgment action of noninfringement of the trade dress in a California federal district court-similar to what was done in Vornado itself. This claim could compel the patentee to bring a counterclaim of patent infringement in that court, with the Ninth Circuit having jurisdiction over any appeal. See Michael A. Cicero, In The Wake Of Holmes v. Vornado: 
Congress's goal of preventing forum shopping is frustrated. And because of these possibilities for gamesmanship, "a race to the court-house" may ensue, with a patentee rushing to file a complaint in district court before its competitor, in order to ensure that the caselaw of the Federal Circuit, and not the competitor's favored RCCOA, will govern the dispute. ${ }^{248}$

There are other more practical problems as well. For instance, the recent inexperience of the RCCOAs in deciding patent issues poses serious questions about the ability of those courts to independently develop patent law at this juncture. It has been twenty years since RCCOAs had full jurisdiction over patent appeals, so deciding patent issues is almost certainly an unfamiliar task for them. ${ }^{249}$ One might argue that RCCOAs have retained some patent experience through hearing patent defenses and other patent issues in cases without patent claims. But many patent issues that appear in appeals of patent claims, such as questions of the appropriate remedies for a successful claim of patent infringement, are unlikely to appear in these cases. And in any case, such experience is still likely to be much less frequent than it would be if hearing appeals of cases with patent claims were part of RCCOAs' regular jurisdiction. 250

Additionally, the ability of RCCOAs to independently develop patent law, coupled with the corollary proposition that RCCOAs do not defer to another circuit's jurisprudence, raises the possibility of serious confusion at the trial level as to the proper standard to apply in the affected cases. The Federal Circuit has had, as noted above, significant success clarifying and standardizing rules in

Patent And Copyright Jurisdiction Now Scattered Throughout Court Systems, at http://www.commlaw.com/FSL5CS/news\%20bites/news\%20bites 1386.asp (originally published in Aug. 20, 2002 issue of Southeast Tech Wire).

But Mr. Cicero appears to be incorrect in his suggestion that the California competitor could file a declaratory judgment action for patent invalidity and then, when the patentee filed a compulsory patent counterclaim in response, escape the Federal Circuit's exclusive jurisdiction in light of Vornado. The competitor's declaratory judgment action would itself be a civil action "arising under" patent law. See, e.g., Franchise Tax Bd. of Cal. v. Constr. Laborers Vacation Trust, 463 U.S. 1, 19 n.19 (1983) ("federal courts have consistently adjudicated suits by alleged patent infringers to declare a patent invalid, on the theory that an infringement suit by the declaratory judgment defendant would raise a federal question over which the federal courts have exclusive jurisdiction"); Kidde, Inc. v. E. F. Bavis \& Assocs., Inc., 735 F.2d 1085 (8th Cir. 1984) (per curiam) (transferring declaratory judgment action for patent invalidity or noninfringement to the Federal Circuit, as such action created $\S 1338$ jurisdiction and thus was under that court's exclusive jurisdiction). The Federal Circuit has adhered to this rule postVornado. See Golan v. Pingel Enterprise, Inc., 310 F.3d 1360, 1367 (Fed. Cir. 2002). Accordingly, the Federal Circuit would have, absent severance, exclusive appellate jurisdiction over the entire case. See supra note 179 and accompanying text.

248. See Cicero, supra note 247.

249. This comment stems from the observation that RCCOA judges would only have significant experience with deciding patent cases to the extent they (1) heard any patent counterclaims prior to Aerojet, or (2) were confirmed prior to 1982 - with an exception for those cases filed before the Federal Circuit came into existence and concluded in the RCCOAs after 1982.

250. In particular, it appears that RCCOAs have heard relatively few cases involving patent defenses; the commonsense explanation is that such defenses are usually presented as defenses to patent claims made by a plaintiff, giving the Federal Circuit jurisdiction. 
areas of patent law that, prior to the court's creation, were neither clear nor uniform. For example, the court has taken significant steps to reshape the standards for patent issues such as inventiveness (particularly the nonobviousness requirement), double patenting, damages, and preliminary injunctions, all areas which now have rules under Federal Circuit precedents that significantly differ from those existing in many RCCOAs prior to $1982 .{ }^{251}$

While many of these rules are now considered established, the old, contrary decisions of the RCCOAs were not necessarily overruled-the Federal Circuit certainly cannot overrule a sister court's decisions. ${ }^{252}$ So unless, for example, the Supreme Court has affirmed the Federal Circuit's decisions (as it has in some areas) those contrary RCCOA decisions technically are still good law. Patent litigants may expect cases to be governed by the Federal Circuit case law with which they are familiar, but district courts may feel bound to apply the (arguably antiquated) patent jurisprudence of their RCCOA, at least until they are instructed otherwise - as a district court is normally bound to apply the law of its circuit. ${ }^{253}$

\section{SUMMARY}

The promise of the Federal Circuit regarding patent claims can be simply stated: "An alleged [patent] infringer no longer may file in a regional circuit with more favorable law to avoid another circuit's law; the law of the Federal Circuit follows patent cases to all corners of the nation." ${ }^{254}$ But as this Part demonstrated, Vornado opens the door to a world in which this promise is no

251. See Dreyfuss, supra note 25 , at $8-19$. In view of the substantial doctrinal developments within the Federal Circuit over the past twenty years and the relative paucity of Supreme Court review of its decisions, such differences have almost certainly only been exacerbated since Dreyfuss's article was published in 1989. For example, in Toxgon Corp. v. BNFL, Inc., 312 F.3d 1379 (Fed. Cir. 2002), the Federal Circuit ruled that the provision giving the Court of Federal Claims exclusive jurisdiction over patent infringement suits against the government was not a jurisdictional bar to an infringement suit against a government contractor, but was rather an affirmative defense. In doing so, the court rejected a party's request to follow "obsolete rules adopted by other circuits" before the creation of the Federal Circuit that held otherwise. Id. at 1382 (citing Croll-Reynolds, Co. v. Perini-Leavell-Jones-Vinell, 399 F.2d 913, 915 (5th Cir. 1968) ("finding that section 1498(a) creates a jurisdictional bar")). After Vornado, however, such rules are no longer obsolete when patent claims exist in a case only as counterclaims.

252. See supra notes $220-28$ and accompanying text.

253. See, e.g., Hart v. Massanari, 266 F.3d 1155, 1170 (9th Cir. 2001) ("A district judge may not respectfully (or disrespectfully) disagree with his learned colleagues on his own court of appeals who have ruled on a controlling legal issue ...."). However, whether district courts apply one circuit's law or another has no bearing on the development of patent law away from the Federal Circuit's precedent, as district court decisions do not control other courts. See, e.g., FutureSource LLC v. Reuters Ltd., 312 F.3d 281, 283 (7th Cir. 2002) ("The reasoning of district judges is of course entitled to respect, but the decision of a district judge cannot be a controlling precedent.").

254. K \& F Mfg. Co. Inc. v. W. Litho Plate \& Supply Co., 831 F. Supp. 661, 663-64 (N.D. Ind. 1993) (holding that Federal Circuit law applied to plaintiff's action for a declaratory judgment of noninfringement and explaining that since the Federal Circuit's creation, a plaintiff seeking such a declaratory judgment "may achieve a more convenient forum [by filing in a particular district court], but cannot achieve a tactical advantage in choice of controlling precedent"). 
longer true, a world potentially plagued by nonuniformity in patent caselaw, patent-based forum shopping, and other problems-without offering commensurate benefits. This situation is undesirable and, as the remainder of the Article will argue, unnecessary.

\section{Preserving Uniformity in Patent Law Through Deference to the Federal Circuit}

There are, of course, two basic questions that come up in any case, and certainly in dealing with a patent claim: What is the appropriate forum for this claim? And what is the appropriate law to apply? Vornado addressed the first question. It interpreted the statutes relating to the Federal Circuit's patent jurisdiction and thus established, for at least the immediate future, the jurisdictional rules for determining which federal appellate court has jurisdiction over the appeal of a case containing a patent counterclaim. In doing so it necessarily construed the meaning of $\S 1338(a)$, on which the Federal Circuit's $\S 1295(a)(1)$ jurisdiction depends, to decide when trial jurisdiction of a case with a patent counterclaim is proper in federal district court.

Vornado did not, however, resolve the second question-what law RCCOAs should apply to patent claims. Indeed, the opinion for the Court did not mention that question at all. And while Justice Stevens may believe that the rule of no deference would necessarily prevent RCCOAs from deferring to the Federal Circuit's patent precedents, no justice joined his separate opinion.

Although Vornado does not answer the choice-of-law question, the rule of no deference potentially does. For a lower federal court, the choice-of-law question is necessarily decided, of course, if there is on-point Supreme Court precedentsuch caselaw must be followed. But rare indeed is the patent case that can be resolved solely by reference to an opinion in the United States Reports. ${ }^{255}$ While RCCOAs are unlikely to ignore the Federal Circuit as a source of persuasive precedents, following the rule of no deference would prohibit them from deferring to its decisions.

Part II.в addressed the serious problems that may occur if RCCOAs, when dealing with issues on which they have some choice as to what law to apply, follow the rule of no deference. Others have recognized these problems as well. ${ }^{256}$ Because, however, so many industry groups and commentators appear to have assumed that the rule of no deference is unalterable (or that it should not be altered), attempts to resolve these problems have focused on jurisdictional solutions that reduce the impact of, or avoid altogether, the choice-of-law

255. In fact, the Court has stated its intent to leave the development of specific patent law rules to the Federal Circuit. See, e.g., Warner-Jenkinson Co. v. Hilton Davis Chem. Co., 520 U.S. 17, 40 (1997) ("We expect that the Federal Circuit will refine the formulation of the test for equivalence in the orderly course of case-by-case determinations, and we leave such refinement to that court's sound judgment in this area of its special expertise.").

256. See supra note 12 and accompanying text. 
issue. ${ }^{257}$ For example, proposed jurisdictional modifications include modifying $\S 1338$ (a) to create exclusive jurisdiction in the federal district courts if there is a patent claim in the case-not just in the plaintiff's complaint-which would restore the Federal Circuit's pre-Vornado control over the appeals of cases with patent claims and counterclaims. ${ }^{258}$ It may be that such proposals present appropriate long-term solutions; Part V.A. discusses the merits of these options relative to deference.But regardless of what, if anything, Congress eventually adopts as a long-term solution, applying the rule of no deference will continue to frustrate congressional intent regarding patent law until then.

Accordingly, Part III explains why RCCOAs, when addressing patent issues presented by patent counterclaims and defenses thereto, should defer to applicable Federal Circuit precedents. ${ }^{259}$ Part III.A demonstrates that, although the traditional justifications for the rule of no deference may make sense for general issues of federal law, they do not apply to patent issues given the regime created by the FCIA. In view of this reality, Part III.B explains how deference to the Federal Circuit would serve the congressional goals for patent law evident in the Federal Circuit's creation. Finally, Part III.c shows how the reasons for deference to the Federal Circuit compare favorably with the reasons underlying established exceptions to the rule of no deference.

\section{A. A NEW PARADIGM: WHY THE RULE OF NO DEFERENCE SHOULD NOT APPLY TO PATENT LAW}

As noted above, the rule of no deference traditionally has been justified in two primary ways: the principle of competence and the benefits of percolation. Neither justification is sufficient in this unique context to justify adhering to the rule of no deference instead of, as this Article recommends, deferring to the patent precedents of the Federal Circuit.

257. See supra note 13-14 and accompanying text; Mosley-Goren, supra note 12, at 42-43.

258. Mosley-Goren, supra note 12, at 29 (discussing the proposal of the Federal Circuit Bar Association (FCBA) to achieve this result); Don Dunner et al., Report of the Ad Hoc Committee to Study Holmes Group, Inc. v. Vornado Air Circulation Systems, Inc, 12 FED. CiR. B.J. 713, 719 (2003) [hereinafter Ad Hoc Committee's Report]. The Ad Hoc Committee-which was created "to study the wisdom of pursuing a legislative response" to Vornado at an FCBA meeting held shortly after the case was decided-proposed just such a jurisdictional modification. Id. at 713, 728. The Committee concluded that "the most appropriate response to Holmes Group and Green is to amend 28 U.S.C. $\S 1338$ to ensure that the district courts have original jurisdiction over all claims for relief arising under the patent laws." Id. at 728 (emphasis added). While the Ad Hoc Committee's Report examined at some length the case for its proposal and against other jurisdictional modifications, it did not list the implementation of deference to the Federal Circuit's patent precedents among the proposals that the Committee had considered and rejected. See id. at 719-26. But in explaining why "the state of the law" post-Vornado "compromises the uniformity of patent law" by "creat[ing] fertile ground for forum shopping," the Report stated that "[a]lthough some degree of comity may be given to Federal Circuit law, the regional circuits are of course bound by their own precedent." $I d$. at 717 .

259. This is a broad statement of the deference that I propose should be given the Federal Circuit; details on the specific scope and level of deference are examined in Part IV, infra. 
1. Congress Intended the Federal Circuit to Have Special Competence in Patent Law

To understand why the principle of competence does not support application of the rule of no deference here, that principle's true nature must be examined. First, it appears that as traditionally understood, the principle of competence is only a presumption, and one that may be rebutted. On this point, Professor Marcus's teachings are instructive; he noted that by setting up courts of appeals independent of each other "subject only to review by the Supreme Court," the Evarts Act system "assumes that the courts of appeals are competent to decide questions of federal law correctly and mandates that they do so." ${ }^{260}$ Implicit, however, in his additional statement that federal courts "are presumptively competent to decide the [issues of federal law]," is that this principle is only a presumption. ${ }^{261}$ What the principle prohibits is "rote acceptance" of the precedents of a coordinate court, ${ }^{262}$ not acceptance of those precedents in limited, specifically justified situations. This point is illuminated by the exceptions to the rule of no deference discussed in Part III.c.

Moreover, while it is often described as the principle of competence, the principle is perhaps better described as one of equal competence. The mere presumption that an appellate court was competent to decide federal law would not seem sufficient to justify the rule of no deference unless it also meant that a coordinate court was no more competent to decide that issue. If such equal competence were not presumed, one court could simply justify deference to a coordinate court by asserting that, while it was technically able to decide an issue independently, another coordinate court had much more experience in that area and thus was more likely to decide that issue correctly. This might occur, for example, in the case of an RCCOA inexperienced with securities regulation cases deciding to defer to the Second Circuit, which regularly handles such cases. It thus seems that it is the presumption that each circuit court of appeals is equally competent to interpret federal law that actually supports the rule of no deference.

Once correctly seen as a presumptive principle of the equal competence of federal courts with respect to federal law, it is easy to see why this principle fails to justify denying deference to the Federal Circuit's precedents in this context. To the extent it rests on a presumption of equal competence, the rule of no deference to coordinate courts is, admittedly, appropriate for a world in which appellate jurisdiction is geographically divided. In such a world, the simple fact that one court of appeals has, perhaps only by happenstance, decided an issue of federal law before another is arguably an insufficient reason to deny later-coming litigants "[the second court's] independent consideration

260. Marcus, supra note 215 , at 702 .

261. Id.

262. Id. (emphasis added). 
and judgment.",263

The establishment of the Federal Circuit, however, with a jurisdiction based not on geography but on subject matter, creates a new paradigm with respect to those areas over which it was granted exclusive jurisdiction. Congress's grant to the Federal Circuit of exclusive, nationwide jurisdiction over the appeals of certain claims rejects the very presumption of equal competence on which the rule of no deference depends. This is particularly true for patent law, an area where Congress focused on the "special need" for uniformity. ${ }^{264}$

This new paradigm recognizes the special competence of the Federal Circuit in patent law. Granted, Congress almost certainly-and for good reason-did not want the Federal Circuit to have jurisdiction over every case in which a patent issue was raised. But Congress granted the Federal Circuit jurisdiction over the appeals of all patent cases (however that term is defined) to address the specific problems caused by the lack of uniformity in patent law, a situation largely created by conflicts in the interpretation of patent law by the RCCOAs. $^{265}$

By taking these cases away from the RCCOAs and creating the Federal Circuit to handle them-and doing so against the background of the presumption that federal courts have equal competence to interpret federal law, and with the specific intent to create uniformity in and improve the administration of patent law-Congress left no doubt that it deemed the Federal Circuit to have special competence in adjudicating patent claims. This conclusion is especially supported by the absence of any evidence within the legislative history that Congress intended for the RCCOAs to retain a corresponding role in resolving such claims on appeal based on the RCCOAs' independent interpretations of patent law. In view of this congressional judgment, the general principle of equal competence does not support applying the rule of no deference when RCCOAs adjudicate patent counterclaims.

\section{Congress Rejected Percolation Benefits in Creating the Federal Circuit}

Percolation theory also fails to justify the application of the rule of no deference in the special context of deference to the Federal Circuit on patent issues created by patent counterclaims. This theory is particularly relevant to post-Vornado discussion given that it was relied on by Justice Stevens in his

263. Heckendorn v. United States, 162 F. 141, 143 (7th Cir. 1908), cited in Marcus, supra note 215, at 703.

264. S. REP. No. 97-275, at 2 (1981), reprinted in 1982 U.S.C.C.A.N. 11, 12; see also Christianson v. Colt Indus. Operating Corp., 822 F.2d 1544, 1551 (Fed. Cir. 1987) ("Though this court's exclusive substantive jurisdiction encompasses six major areas of national law in which Congress desired greater uniformity, of which patent law is but one, the Seventh Circuit correctly noted the Congressional emphasis on the need for greater uniformity in patent law and for freeing the judicial process from the forum shopping caused by conflicting patent decisions in the regional circuits.") (citing S. REP. No. 97-275, at 5-6, 1982 U.S.C.C.A.N. at 15-16).

265. See supra notes $25-41$ and accompanying text. 
separate opinion. ${ }^{266}$ As mentioned above, Justice Stevens saw the outcome in Vornado as an opportunity to produce conflicts that would aid the Supreme Court in finding patent issues worthy of its review, and added that "occasional decisions by courts with broader jurisdiction will provide an antidote to the risk that the specialized court may develop an institutional bias."267

While there is some independent merit to Justice Stevens's argument in favor of percolation in patent law, he gives insufficient weight to Congress's basic goal with respect to patent law since the creation of the Federal Circuit: uniformity. In fact, he entirely overlooks the disparity in patent jurisprudence among the RCCOAs that was a central motivation for the Federal Circuit's creation in the first place. Given that history, the prospect of returning to such disparity-even in limited circumstances-is not to be celebrated. The clear congressional intent in this regard compels the conclusion that the benefits of percolation cannot justify allowing RCCOAs unconstrained interpretive freedom when they adjudicate patent counterclaims.

Moreover, the advantages Justice Stevens sees in allowing intercircuit conflicts to develop so that the Supreme Court can resolve them are belied by the

266. See Holmes Group, Inc. v. Vornado Air Circulation Sys., Inc., 535 U.S. 826, 839 (2002) (Stevens, J., concurring in part and concurring in the judgment); see supra notes 13 and accompanying text.

Unsurprisingly, Vornado was not the first case in which Justice Sevens had alluded to percolation benefits. See McCray v. New York, 461 U.S. 961, 962-63 (1983) (Stevens, J. respecting the denial of petitions for writs of certiorari) (stating with respect to a constitutional issue for which there "presently [was] no conflict of decision within the federal system" that "I believe that further consideration of the substantive and procedural ramifications of the problem by other courts will enable us to deal with the issue more wisely at a later date. ... In my judgment it is a sound exercise of discretion for the Court to allow the various States to serve as laboratories in which the issue receives further study before it is addressed by this Court") (citations omitted), cited in Marcus, supra note 215, at $690 \mathrm{n} .85$. Unlike what is typically the case when "percolation" theory is invoked with respect to a case in federal court, Justice Stevens' opinion in McCray argued in favor of allowing issues of state, not federal, law to percolate. While the benefits of percolation appear similar in both circumstances, current litigants in federal courts might find Stevens' reliance on that theory in McCray less objectionable than usual: instead of postponing, as in the typical case, the resolution of conflicts over issues of federal law-sacrificing those litigants forced to suffer under incorrect interpretations of that law while the issues are "fully air[ed]," see id. at 690-Stevens' variant in McCray only postpones reexamination of a federal issue for which there was no current conflict-meaning that no litigant will suffer from the Court's delay simply because of the particular circuit that will hear his appeal-so as to observe the development of analogous state-law issues which the Court was, in any event, powerless to resolve.

Nonetheless, at least one other member of the Court does not share Justice Stevens' views as to the benefits of percolation:

If we were talking about laboratory cultures or seedlings, the concept of issues 'percolating' in the courts of appeals for many years before they are really ready to be decided by the Supreme Court might make some sense. But it makes very little sense in the legal world in which we live.... It is of little solace to a litigant who lost years ago in a court of appeals decision to learn that his case was part of the 'percolation' process which ultimately allowed the Supreme Court to vindicate his position.

William H. Rehnquist, The Changing Role of the Supreme Court, 14 FLA. ST. U. L. REv. 1, 11 (1986), cited in Weis, supra note 219 , at 462.

267. Vornado, 535 U.S. at 839. 
infrequency with which the Supreme Court has traditionally taken up patent cases. ${ }^{268}$ Indeed, in the pre-Federal Circuit era when intercircuit conflicts on patent law abounded, ${ }^{269}$ the Supreme Court rarely granted certiorari to resolve these conflicts. While the Supreme Court frequently has been criticized for its inability to resolve intercircuit conflicts in federal law generally, ${ }^{270}$ in patent law this inability (or perhaps simply hesitancy) historically has been perceived as an even greater problem. According to one commentator, "some perceived the Court's [pre-Federal Circuit] involvement in patent infringement cases as so limited that the nine circuit courts effectively were functioning as 'nine different courts of last resort." 271 Congress identified this situation as a core reason for creating the Federal Circuit, concluding that " $[t]$ he infrequency of Supreme Court review leaves the present judicial system without any effective means of assuring even-handedness nationwide in the administration of the patent laws.",272 And the yearly rate of decisions addressing issues of patent law and policy appears to have slightly decreased since the creation of the Federal Circuit, ${ }^{273}$ with only a fraction of these decisions squarely addressing substantive issues of patent law. ${ }^{274}$ When one considers these concerns in light of the substantial decrease over the past decade in the number of opinions the Supreme Court issues each term, ${ }^{275}$ the truly illusory nature of any percolation benefits in patent law becomes clear.

At bottom, percolation theory depends on a view that the Evarts Act structure necessarily sacrifices the goal of short-term uniformity in federal law through deference to the opinions of coordinate courts for the long-term benefits of allowing each circuit (and each state supreme court, where applicable) to reach different views on federal law. But at least as concerns the adjudication of

268. See infra notes $271-274$ and accompanying text.

269. See supra notes $25-30$ and accompanying text.

270. See Marcus, supra note 215 , at 689 (citations omitted).

271. Mark D. Janis, Patent Law in the Age of the Invisible Supreme Court, 2001 U. ILL. L. Rev. 387, 391 (2001) (citation omitted).

272. H.R. REP. No. 97-312, at 22. At least one opponent of the Federal Circuit's creation disagreed with this justification. See S. REP. No. 97-275, at 41, (1982) U.S.C.C.A.N. at 50 (additional views of Senator Max Baucus) ("[C]reating a specialty court will not remove ambiguity. The Supreme Court has addressed patent law in approximately 15 cases over the last 20 years, and the experts agree that their holdings have not adequately resolved existing ambiguity in the patent law area. The problem has not been the Supreme Court's unwillingness to hear cases, but rather the decision[s] it has made. If that is the case, then the appropriate Congressional response should be substantive reform rather than passing the issue on[to] the new court.").

273. See Donald S. Chisum, The Supreme Court and Patent Law: Does Shallow Reasoning Lead to Thin Law?, 3 Marq. Intell. Prop. L. Rev. 1, 2-3, 23 (1999) (showing that from 1950-81, the Supreme Court heard nineteen patent law cases-a rate of 1 every 1.63 years; and that from 1982-99, the Supreme Court heard seven-a rate of 1 every 2.43 years.

274. See Janis, supra note 271 , at 388 n.2.

275. See Tony Mauro, The High Court's Incredible Shrinking Docket, American Lawyer Media, at http://www.law.com/jsp/article.jsp?id=1046833521897 (Mar. 10, 2003) (concluding that the 2002-03 Term Court was heading toward less than seventy-five total opinions, "on the low end of the number of opinions issued per term for the last decade or so, when the Court shrank its decision docket below 100 cases"). 
patent claims, this argument of intent is not sustainable. The fact remains that Congress unmistakably desired uniformity in creating the Federal Circuitindeed, Congress was motivated to create the Federal Circuit by the Supreme Court's failure to sufficiently resolve "percolating" intercircuit conflicts in patent law. Consequently, percolation theory also fails to support applying the rule of no deference in this special context.

\section{B. UNIFORMITY, CONGRESSIONAL INTENT, AND PATENT LAW}

Recognizing that the traditional reasons supporting the rule of no deference are inapplicable in this context does not prove that deference should be given. Rather, it merely opens the deference question for further discussion. But a principal consideration in this analysis must surely be the effectuation of congressional intent. As will be shown in more detail below, accounting for that factor makes the case for deference to the Federal Circuit especially persuasive. Simply put, RCCOA deference to the Federal Circuit on patent issues would effectuate congressional intent, and particularly the goals of uniformity in patent jurisprudence and the avoidance of patent-based forum shopping manifest in the Federal Circuit's creation.

The idea that uniformity concerns should influence legal interpretation at all is not unique to patent issues. There can be little doubt that the goal of uniformity has been recognized as an integral aspect of federal jurisprudence. ${ }^{276}$ But as, for example, Judge Frank Easterbrook has remarked, uniformity concerns are also central to the question of what court should have interpretative responsibility in certain areas:

The Federal Circuit's exclusive jurisdiction under $\S 1295(a)(1)$ was created, after all, so that there could be a uniform jurisprudence of patent law... The regional circuits are better situated than the Federal Circuit to mull over questions of local law; "uniformity" interests cut in favor of distributing state law issues to courts with geographic jurisdiction, even as they support central handling of patent questions. ${ }^{277}$

Of course, Vornado makes it clear that, in the absence of congressional action, all patent claims will no longer be "centrally handled" by the Federal Circuit. But simply because the Supreme Court determined in that case and Christianson that the Federal Circuit does not have jurisdiction over every appeal involving a patent issue or claim does not mean that Congress desired the independent development of a patent jurisprudence by other appellate courts. In fact, the evidence appears undisputed that what Congress intended in establishing the Federal Circuit was a uniform patent-law jurisprudence, and that incorporation of $\S 1338$ (a)'s language in setting the Federal Circuit's

276. See, e.g., supra note 229 and accompanying text.

277. Kennedy v. Wright, 851 F.2d 963, 966 (7th Cir. 1988). 
appellate jurisdiction was simply a clear way to achieve that goal. ${ }^{278}$ In fact, and as examined in detail above, it appears most likely that Congress simply assumed that the Federal Circuit would have jurisdiction over patent counterclaims. If that was Congress's intent, then RCCOAs are justified in deferring to the Federal Circuit's precedents when adjudicating the patent counterclaims that Congress thought would be exclusively adjudicated on appeal by the Federal Circuit.

But even if one argues that the legislative history is too ambiguous to conclude that Congress had such an intent, deference to the Federal Circuit in this regard serves Congress's clearly-stated broad goals in creating that court. Congress repeatedly exclaimed a goal of nationwide uniformity in patent law. ${ }^{279}$ Deference to the Federal Circuit, the judicial body in which Congress reposed the responsibility to achieve this uniformity, serves that broad intent. Manifestly, applying the Federal Circuit's law to all patent claims-whether patent claims brought in a complaint and decided by the Federal Circuit or patent counterclaims falling outside of $\S 1338$ and decided by RCCOAs-would serve the goal of uniformity in patent law. Not doing so would just as clearly impede that goal.

Moreover, there can be no serious claim that Congress's intent that the well-pleaded complaint rule govern the Federal Circuit's jurisdiction-to whatever extent it can be said to have so intended-represents an intent to retain an avenue for nonuniform adjudication of patent claims. But that is what application of the rule of no deference here would allow. Again, the cases and articles discussing Congress's decision to base the Federal Circuit's jurisdiction on traditional "arising under" jurisdictional principles lead almost inexorably to the conclusion that this choice, while perhaps indicating an intent to prevent the Federal Circuit from taking jurisdiction over all cases in which patent issues are raised, ${ }^{280}$ did not reflect a desire to retain intercircuit conflicts in patent law. ${ }^{281}$

Deference to the Federal Circuit also serves the goal of preventing of patent-based forum shopping, another interest instrumental in motivating the Federal Circuit's creation. The case here is fairly simple: If parties know that RCCOAs will apply the precedents of the Federal Circuit to patent issues raised

278. See, e.g., Christianson, 486 U.S. at 814 ("cases fall within the Federal Circuit's patent jurisdiction "in the same sense that cases are said to "arise under" federal law for purposes of federal question jurisdiction'”) (quoting H.R. REP. No. 97-312, at 41); $c f$. Donofrio \& Donovan, supra note 46, at 1850 ("By granting the Federal Circuit case jurisdiction under s 1338, Congress intended to delineate a bright line for purposes of determining which actions the new circuit was to take on appeal.") (citing H.R. REP. No. 97-312, at 23).

279. See, e.g., supra note 39 and accompanying text.

280. See supra notes 166-169 and accompanying text; $c f$. Aerojet-General Corp. v. Machine Tool Works, Oerlikon-Buehrle Ltd., 895 F.2d 736, 744 (Fed. Cir. 1990) (en banc) ("Congress did not require that this court 'get its hands on every appeal involving an allegation that a patent issue is somehow involved"') (quoting Atari, Inc. v. JS \& A Group, Inc., 747 F.2d 1422, 1429 (Fed. Cir. 1984)), overruled sub silentio on other grounds by Holmes Group, Inc. v. Vornado Air Circulation Sys., 535 U.S. 826 (2002).

281. See supra notes $37-41,172-177$ and accompanying text. 
by the patent counterclaims they hear, then their motivation to forum shop is greatly reduced. Concededly, however, deference would not eliminate forumshopping incentives entirely. For example, a party may still prefer an RCCOA's jurisdiction if they think that court will misapply Federal Circuit precedents in a favorable manner, ${ }^{282}$ although the much-improved coherence of patent law since the Federal Circuit's creation should minimize this problem. In addition, a party that knows that its case presents an open issue under Federal Circuit precedents might prefer an RCCOA's jurisdiction if it thinks the RCCOA will resolve that issue favorably. Nevertheless, deference to the Federal Circuit in this context certainly would advance congressional goals regarding forum shopping more than would adherence to the rule of no deference.

\section{COMPARISON TO OTHER CHOICE-OF-LAW EXCEPTIONS}

The suggestion that deference is appropriate under choice-of-law principles finds support in other areas in which RCCOAs have voluntarily departed from the rule of no deference to apply some level of deference to decisions of another federal appellate court. Comparison with these other areas demonstrates that the reasons for deferring to the Federal Circuit on patent law issues are at least as strong as those justifying established exceptions to the rule of no deference.

There is, of course, a long line of cases governing the deference federal courts must give the decisions of the state supreme courts in determining issues of state law. Generally speaking, a federal court sitting in diversity will apply the caselaw of state courts to issues of state law; if the state's highest court has not yet conclusively resolved a question, the federal court will predict how that state court would currently decide it. ${ }^{283}$

On first impression, it might appear that such cases would be instructive in determining reasons to depart from the rule of no deference when, following Vornado, RCCOAs once again adjudicate patent counterclaims. But Erie-type

282. This possibility is raised by the very reasons Congress identified for creating the Federal Circuit. While the lack of uniformity in patent jurisprudence was clearly identified as a problem, it was viewed as having two aspects: first, where "the appellate courts reach inconsistent decision[s] on the same issue," and second, where "although the rule of law may be fairly clear-courts apply the law unevenly when faced with the facts of individual cases." S. REP. No. 97-275, at 3, 1982 U.S.C.C.A.N. at 13. In fact, the latter concern may have been viewed as even more pressing. See H.R. REP. No. 97-312, at 21. Deference to the Federal Circuit's precedents addresses the first aspect, as it ensures that the laws applied in patent cases are uniform. But since RCCOAs could still misapply those precedents as a result of, for example, their inexperience with patent issues, deference may not fully address the second aspect-but other than substantially clarifying the underlying statutes, there may be little that can.

283. Jed I. Bergman, Note, Putting Precedent in its Place: Stare Decisis and Federal Predictions of State Law, 96 Colum. L. Rev. 969, 969 \& n.3 (1996) (citing Salve Regina Coll. v. Russell, 499 U.S. 225, 241 (1991) (Rehnquist, C.J., dissenting) ("[T]he courts' task is to try to predict how the highest court of that State would decide the question. ..."); Meredith v. City of Winter Haven, 320 U.S. 228, 234 (1943) (prior state cases "must be taken as controlling here unless it can be said with some assurance that the Florida Supreme Court will not follow them in the future"); see also Erie R.R. Co. v. Tompkins, 304 U.S. 64 (1938). 
deference arises from a statutory mandate-the Rules of Decision Act-and the body of precedent interpreting it post-Erie. ${ }^{284}$ So while the extent to and situations in which federal courts must follow state law instead of independently reaching the "best" result has been resolved by judicial decision, the general thrust of the analysis (i.e., that state "laws" shall serve as rules of decision in diversity cases) was provided by Congress.

Accordingly, in determining the reasons why federal courts can and should voluntarily (that is, in the absence of any explicit statutory mandate) apply or defer to the patent jurisprudence of the Federal Circuit, it is more useful to examine other situations in which federal courts actually have voluntarily departed from the general rule of no deference. Such situations are, admittedly, rare; as shown above, the rule of no deference appears settled as a general principle. But it is not a universal one, as federal courts of appeals have, in a few areas, chosen to defer to the decisions of other federal courts of appellate jurisdiction.

RCCOAs have voluntarily departed from the general rule of no deference in at least three areas: the Federal Circuit's deference to the RCCOA from which the case originated on nonpatent issues; the "home circuit" rule, where some RCCOAs, in interpreting unsettled questions of state law, defer to the interpretation of the "local" RCCOA absent clear indications of misinterpretation; and the deference newly-formed courts of appeals have chosen to give to the precedents of their predecessor courts unless sitting en banc. By comparing the reasons for deference to the Federal Circuit with the reasons for deference in those situations, it becomes clear that the case for deference to the Federal Circuit is especially strong.

\section{Deference by the Federal Circuit to RCCOAs on Nonpatent Issues}

Perhaps the most relevant area of comparison is the choice-of-law jurisprudence of the Federal Circuit itself. Over the years, the Federal Circuit has been presented with novel choice-of-law questions stemming from its unique jurisdictional status. While the appellate jurisdiction of RCCOAs is generally based on geography, the Federal Circuit's jurisdiction is exclusively based on subject matter, in particular (for present purposes) the presence of a claim "arising under" the patent laws. ${ }^{285}$ Because the Federal Circuit has jurisdiction over cases, and not just patent issues, it had to deal with the question of what law to apply to nonpatent issues in cases within its exclusive jurisdiction. ${ }^{286}$

The Federal Circuit did not adopt its choice-of-law rules because of any statutory mandate, but because it believed that the rules it selected best served

284. See Bergman, supra note 283 , at $969 \mathrm{n} .2$ ("It is more accurate to credit this proposition to the authority of the Rules of Decision Act [than to Erie].").

285. See Schaffner, supra note 219 , at 1176 (Federal Circuit has jurisdiction over an entire case if jurisdiction of district court was at least partly based on $\$ 1338$ ).

286. Id. at 1177 . 
Congress's reasons for creating it in the first place. As mentioned above, the Federal Circuit applies its own law to substantive issues of patent law, and "generally" applies the law of the circuit in which the district court sits to nonpatent issues. ${ }^{287}$ The deference the Federal Circuit applies to nonpatent issues is conclusive; it will not challenge the merits of the RCCOA precedent. ${ }^{288}$ Moreover, for open questions, the Federal Circuit will attempt to predict how the RCCOA would have ruled, and will not exercise independent judgment to reach what it would itself view as the "best" answer. ${ }^{289}$

The court recognizes that the line between "patent issues" and "nonpatent issues" is not always obvious, so it has set guidelines for this determination. In particular, it has held that an issue

that is not itself a substantive patent law issue is nonetheless governed by Federal Circuit law if the issue pertains to patent law, if it bears an essential relationship to matters committed to [the] exclusive control [of the Federal Circuit] by statute, or if it clearly implicates the jurisprudential responsibilities of [the Federal Circuit] in a field within its exclusive jurisdiction. ${ }^{290}$

As this is by no means a bright-line rule capable of easy reference, for ease of discussion a "nonpatent" issue for present purposes is one to which the Federal Circuit will not apply its own law.

Making the delineation of patent versus nonpatent issues even trickier is the Federal Circuit's expansion, over time, of the scope of issues subject to its law, which has grown well beyond substantive issues of patent law into areas "in which the disposition of nonpatent-law issues is affected by the special circumstances of the patent law setting in which those issues arise."291 As explained in Midwest Industries, Inc. v. Karavan Trailers, Inc., the Federal Circuit's law applies to the following areas:

questions such as whether the district court has personal jurisdiction over the defendant in a patent suit; whether the plaintiff has established its right to a preliminary injunction in a patent case; whether there is a sufficient controversy between the parties to permit an accused infringer to bring an action seeking a declaratory judgment of patent noninfringement or invalidity; whether a patentee is entitled to have the issue of inequitable conduct tried in the jury

287. Midwest Indus. v. Karavan Trailers, Inc., 175 F.3d 1356, 1359 (Fed. Cir. 1999).

288. See Panduit Corp. v. All States Plastic Mfg. Co., 744 F.2d 1564, 1575 (Fed. Cir. 1984), overruled on other grounds, 472 U.S. 424 (1985) ("When we review procedural matters that do not pertain to patent issues, we sit as if we were the particular regional circuit court where appeals from the district court we are reviewing would normally lie.... Where the regional circuit court has spoken on the subject, we must apply the law as stated.").

289. See id.; Kohus v. Toys R US, Inc., 282 F.3d 1355, 1358 n.4 (Fed. Cir. 2002) ("When a circuit has not addressed an issue, we must determine how that circuit would likely resolve the issue ....") (internal quotation mark omitted).

290. Midwest, 175 F.3d at 1359 (internal citations and quotations omitted).

291. Id. at 1359-60. 
trial that the patentee has demanded on the issue of infringement; and whether particular materials are relevant for purposes of discovery in a patent case under Fed. R. Civ. P. $26{ }^{292}$

But even in extending its application of its own laws in this manner, the court professes to serve congressional intent. In particular, the expressed purposes of the Federal Circuit's choice-of-law rules reflect that court's view of the role Congress intended it to play in the federal system. For patent issues, the Federal Circuit applies its own law to "serve one of the principal purposes for the creation of this court: to promote uniformity in the law with regard to subject matter within [its] exclusive appellate jurisdiction."293 For nonpatent issues, however, the court has decided that applying the law of the appropriate regional circuit is proper for two main reasons. One reason is "to avoid the risk that district courts and litigants will be forced to select from two competing lines of authority based on which circuit may have jurisdiction over an appeal that may ultimately be taken." ${ }^{294}$ A second reason is "to minimize the incentive for forum-shopping by parties who are in a position to determine, by their selection of claims, the court to which an appeal will go."295 The Federal Circuit's decision not to apply its own law to certain issues of federal law should be contrasted with what blindly following the rule of no deference would have required: that the Federal Circuit independently decide (subject to Supreme Court precedent, of course) all federal issues in the case.

Perhaps unsurprisingly, the very same reasons underlying the Federal Circuit's choice-of-law rules support RCCOA deference to the patent precedents of the Federal Circuit when adjudicating patent counterclaims. Just as the Federal Circuit's choice-of-law rules strive to ensure that nonpatent claims are treated the same way they would be if the appropriate RCCOA heard their appeal, RCCOAs should strive to ensure that patent counterclaims will be adjudicated as they would if their appeal had been heard by the Federal Circuit. Such deference to the Federal Circuit will serve the congressional purposes for which that court was created, just as the Federal Circuit's own choice-of-law rules attempt to do. Surely it cannot be said that RCCOAs should ignore the clear congressional goals regarding patent law evident from the Federal Circuit's enabling act and surrounding history.

Furthermore, as the discussion in Part III.A demonstrates, Congress's creation of the Federal Circuit established a new paradigm within the federal court system, a paradigm in which the Federal Circuit has special competence in patent law. The Federal Circuit has implicitly recognized the limits of this paradigm and has appropriately decided to defer to the law of RCCOAs on

292. Id. at 1359 (internal citations omitted).

293. Id. (citing S. REP. No. 97-275, at 5 (1981), reprinted in 1982 U.S.C.C.A.N. 11, 15).

294. Id.

295. Id. 
nonpatent issues that are not unique to the Federal Circuit's exclusive jurisdiction $^{296}$ or that do not "clearly implicate[]" that Circuit's "jurisprudential responsibilities" in that area. ${ }^{297}$ Given this background, it is equally appropriate for RCCOAs to recognize the new paradigm and accordingly defer to the Federal Circuit on patent issues that are unique to or that do clearly implicate the Federal Circuit's exclusive jurisdiction or responsibilities. Such deference is particularly justified since these issues would have been decided by the Federal Circuit had the claims they stemmed from been brought by the plaintiff instead of by the defendant. ${ }^{298}$

\title{
2. Deference to the "Home Circuit" on Open Issues of State Law
}

Another area of useful comparison is the voluntary deference some RCCOAs pay to the prediction of the "local" RCCOA (that is, the circuit court of appeals embracing the relevant state) on an "unsettled" issue of state law-what the D.C. Circuit has called the "home circuit" rule. ${ }^{299}$ This rule was first formulated (though not under that name) by the Second Circuit in Factors Etc., Inc. v. Pro Arts, Inc. ${ }^{300}$ In that case, Judge Jon O. Newman "wisely concluded" ${ }^{301}$ that:

\begin{abstract}
Where, as here, the pertinent court of appeals has essayed its own prediction of the course of state law on a question of first impression within that state, the federal courts of other circuits should defer to that holding, perhaps always, and at least in all situations except the rare instance when it can be said with conviction that the pertinent court of appeals has disregarded clear signals emanating from the state's highest court pointing toward a different rule. ${ }^{302}$
\end{abstract}

The Abex court adopted this rule for the D.C. Circuit as well. Instead of following the rule of no deference, which would require the D.C. Circuit to make its own prediction of how the state court would address the open issue, ${ }^{303}$ the court "will defer to the local circuit's view of the law of a state in [the local circuit's] jurisdiction when that circuit has made a reasoned inquiry into state

296. Regents of Univ. of N.M. v. Knight, 321 F.3d 1111, 1117 (Fed. Cir. 2003) ("In deciding issues not unique to our exclusive jurisdiction, we apply the law of the regional circuit in which the district court sits").

297. Midwest, 175 F.3d at 1359 (quoting Gardco Mfg., Inc. v. Herst Lighting Co., 820 F.2d 1209, 1212 (Fed. Cir. 1987)).

298. Situations in which deference on what the Federal Circuit considers a patent issue may be inappropriate are discussed below when the appropriate level of deference is examined. See infra Part IV.B.

299. See Charter Oil Co. v. Am. Employers' Ins. Co., 69 F.3d 1160, 1164 (D.C. Cir. 1995).

300. 652 F.2d 278, 283 (2d Cir. 1981).

301. Abex Corp. v. Maryland Cas. Co., 790 F.2d 119, 125 (D.C. Cir. 1986) (Edwards, J.).

302. Factors Etc., 652 F.2d at 283.

303. For a discussion of the relevance of the fact that prediction of state law and interpretation of federal patent law involve different analytical tasks, see infra notes 317-20 and accompanying text. 
law." 304 The local circuit's prediction on the issue is binding unless the court is "convinced that the [local circuit] has ignored clear signals emanating from the state courts. Only when we are certain that the pertinent circuit has clearly misread state law would it make sense to reject that circuit's view of state law." 305

Although the situations where courts will deny deference under this rule are "rare," ${ }^{306}$ they do arise on occasion. For example, in a later case, the D.C. Circuit refused to accept the Eighth Circuit's determination of Missouri law on the principle that "[d]eference is one thing; blind adherence quite another."307 Other circuits, including the Fourth, ${ }^{308}$ Sixth, ${ }^{309}$ and Seventh ${ }^{310}$ Circuits, have also applied the general rule, if not always explicitly recognizing it by this name. It is, however, unclear whether the Federal Circuit recognizes "home circuit" deference, which is somewhat surprising given its clear willingness to defer to RCCOA precedents on nonpatent issues generally. ${ }^{311}$

The D.C. Circuit cases invoking this rule concisely explain its rationale. One factor supporting the rule is the assumption that the judges of the local RCCOA will be more experienced in interpreting that state's law, so that deference to their interpretation will provide "uniform results taking advantage of that expertise. ${ }^{312}$ Another reason, somewhat connected to the first one in terms of uniformity concerns, is the avoidance of the "evils of forum shopping, which the Erie doctrine is designed in part to prevent." ${ }^{313}$ Such evils would only be heightened by the "oddity" of a split in the circuits over the correct application of a state's law; deference to the local RCCOA's interpretation avoids this

304. Abex, 790 F.2d at 125 .

305. Id. at 125-26.

306. Factors, Etc., 652 F.2d at 283.

307. Indep. Petrochem. Corp. v. Aetna Cas. \& Sur. Co., 944 F.2d 940, 945 (D.C. Cir. 1991).

308. See Mellon Bank, N.A. v. Ternisky, 999 F.2d 791, 796 (4th Cir. 1993) ("We cannot say that the Third Circuit, in reviewing the district court's interpretation of state law de novo ... 'disregarded clear signals emanating from [Pennsylvania's] highest court pointing to a different rule.' Therefore, we defer to the Third Circuit's interpretation of Pennsylvania law.") (quoting Factors Etc., 652 F.2d at 283) (internal citations omitted).

309. See U.S. v. Maness, 23 F.3d 1006, 1008-09 (6th Cir. 1994) (stating that "[b]ecause North Carolina is located within the Fourth Circuit, we would usually defer to the Fourth Circuit's prediction of an issue of first impression regarding North Carolina state law" but disregarding the Fourth's Circuit's prediction in the particular case as possibly contrary to Supreme Court precedent and because it ignored on-point state precedent).

310. See Dawn Equip. Co. v. Micro-Trak Sys., Inc., 186 F.3d 981, 989 n.3 (7th Cir. 1999) ("[W]e normally defer to a sister circuit's interpretation of the law of a state within its jurisdiction.").

311. See Rambus, Inc. v. Infineon Tech. AG, 318 F.3d 1081, 1087 n.2. (Fed. Cir. 2003). In Rambus, the Federal Circuit was faced with an uncertain question of Virginia law. It looked to a Fourth Circuit precedent that appeared relevant but discounted its applicability; because the precedent's conclusion appeared unsupported by the cases it relied on, the Rambus court decided that the case provided "limited insight." Id . Arguably, then, the local circuit's precedent analyzed in Rambus simply failed to meet the home circuit rule's implicit requirement that the prediction involve a "reasoned inquiry" into state law. See also Abex, 790 F.2d at 125.

312. Charter Oil, 69 F.3d at 1164.

313. Abex, 790 F.2d at 125. 
problem. $^{314}$

The Second Circuit in Factors, Etc. added to these explanations the benefit of "orderly development" of the law "because the state legislature will know that the decision of the pertinent court of appeals will determine legal rights, unless superseded by a later state supreme court decision." This, in turn, would improve the ability of the state legislature to determine "the appropriateness of a statutory change." 315 Related to forum-shopping concerns, the Factors, Etc. court also believed this rule promoted "fairness to the public" by producing "a single, authoritative answer to the particular state law issue." 316

These same reasons support deference to the Federal Circuit when RCCOAs address patent counterclaims. Federal Circuit judges are far more experienced in deciding patent issues now than the judges of any RCCOA have ever beeneven before 1982. Now that twenty years have passed since RCCOAs last regularly heard patent appeals, the experience gap has only grown larger. Relying on the Federal Circuit's expertise by deferring to the its jurisprudence on patent issues will produce uniform results and minimize the incentive of litigants to opportunistically file permissive counterclaims in cases where no patent claim is presented in the complaint. The result will be the preservation of the fairly uniform patent jurisprudence that the Federal Circuit has produced, allowing the patent-affected public to be more confident of the particular jurisprudence under which their claims are adjudicated and aiding Congress in deciding when it may be appropriate to change the patent statutes that this jurisprudence interprets.

Because the federal court never would have had the obligation to independently determine state law, the "home circuit" rule would seem on initial observation less a full exception to the rule of no deference than the other listed exceptions. In the situations governed by the rule, the RCCOA is not abdicating the ability to independently determine the law, but rather its obligation to predict how the state court would resolve the issues at hand. Indeed, Professor Schaffner, when supporting a statement that "no regional circuit feels precedentially bound to follow the law of a sibling circuit court," discounted the relevance of the deference exercised in cases like Factors, Etc. and Abex by noting that those cases involved issues of state, not federal, law. ${ }^{317}$

But it would be erroneous to conclude that this fact makes the "home circuit" rule any less of an exception to the rule of no deference-or that the reasons for deferring to a coordinate court's prediction of state law under that rule are irrelevant to the case for deferring to the Federal Circuit's interpretation of

314. Id.

315. Factors, Etc., 652 F.2d at 282.

316. Id.; see also Indep. Petrochem, 944 F.2d at 944 ("The potential for forum-shopping within the federal judicial system caused by intercircuit conflicts over the meaning of state law, and the assumption of expertise on the part of the home circuit, have led us to conclude that a home circuit's view of state law is entitled to deference.").

317. Schaffner, supra note 219 , at $1195 \&$ n. 148 . 
patent law as proposed in this Article. As Professor Marcus observed, the fact remains that, notwithstanding the relatively recently adopted exceptions to the rule of no deference discussed in this subpart, federal courts have not traditionally deferred to one another even on issues of state law; ${ }^{318}$ as Marcus explains, the "rule of competence applies [to these determinations] as well."319 Accordingly, the background rule is that "it is the responsibility of each federal court to make its own interpretation of uncertain state law rather than following the interpretation of another federal court." 320 That latter conclusion is crucial, because so long as the "home circuit" rule represents a departure from the presumption that federal courts are equally competent to predict state laweven if that competence is less than in interpreting federal law-the reasons that justify deference under that rule are available for analogy to other areas. In other words, although the competency is in a different task (prediction rather than independent interpretation), these cases nonetheless establish reasons why, even in the face of that presumed equality, deference is justifiable.

This conclusion is further supported by the reality that prediction of state law is not a routine task. Unlike the application of established state law, which is usually less complicated, prediction of open issues of state law is undeniably complex. ${ }^{321}$ A court's unfamiliarity with a state's law-as is the case in situations governed by the "home circuit" rule-can only make that task more difficult.

Finally, despite the distinctions between the analytical construct used in the prediction of state law and that used the interpretation of federal law, there is at least one way in which the "home circuit" rule is like all exceptions to the rule of no deference: the possibility that the deferring court will apply the home circuit's prediction of state law even though, had the deferring circuit undertaken an independent analysis, it might have predicted differently. This common factor-the limitation of a court's ability to reach a different (perhaps better, perhaps worse) result through exercise of its independent judgment-makes it

318. Marcus, supra note 215 , at $704 \mathrm{n} .166$ (also concluding that criticism of the holding in Factors, Etc. demonstrated that "the principle of competence is firmly entrenched"). It should be noted, though, that Marcus's article was written before the "home circuit" rule was formally adopted anywhere outside of the Second Circuit (Abex, for example, came two years later).

319. Id. This statement might initially appear to conflict with Marcus's earlier-quoted comment that federal courts "lack competence to decide [state law issues] and are presumptively competent to decide [federal law issues]." Id. at 702. It seems clear, though, that in this statement Marcus was referring to federal courts' lack of competence to independently interpret state law, not to their competence in predicting it. After all, if federal courts were not even competent to predict state law, there would be no reason to allow them to do it.

320. Id. at 704 n.166. Professor Marcus does note the apparently more-recognized exception that "[s]ome courts will defer to an interpretation of state law by a district judge who sits in that state, on the theory that he is more familiar with it." Id. (citing Charles A. Wright, The Law of Federal Courts $\S 58$, at $375-76$ (4th ed. 1983)).

321. See, e.g., Bergman, supra note 283, at 976 (discussing the complexity of predicting how a state's highest court would resolve an open issue). 
instructive to analyze the justifications offered for the "home circuit" rule in evaluating the rule of deference that this Article recommends.

\section{Deference to a Predecessor Court}

A final area of comparison is the deference some newly-formed federal courts of appeals have paid to the decisions of predecessor courts, even though the rule of no deference would counsel otherwise. Of particular interest are the decisions of the Federal Circuit and the Eleventh Circuit, soon after their formation, to apply as binding precedent the decisions of their respective predecessor courts handed down prior to their creation-even though neither one of their enabling statutes required them to do so.

The Eleventh Circuit was created in 1981 by taking Alabama, Florida, and Georgia from the Fifth Circuit, leaving the "new" Fifth with Texas, Louisiana, Mississippi, and the District of the Canal Zone. ${ }^{322}$ The creation of the Federal Circuit, however, involved the abolition of the Court of Claims and the Court of Customs and Patent Appeals (CCPA). ${ }^{323}$ Both courts, however, sat en banc in their first cases to decide what circuit's law-if any-would serve as their precedents. ${ }^{324}$ Surprisingly, this question had not been addressed by either circuit's enabling act. ${ }^{325}$ As luck would have it, ${ }^{326}$ both courts resolved their choice-of-law dilemmas identically: Both decided to adopt as binding precedent the decisions of their predecessor courts, and both chose to require an en banc sitting to overrule such decisions.

In Bonner v. City of Prichard, the Eleventh Circuit, while recognizing the traditional rule that decisions of one circuit are not binding on other circuits, nevertheless adopted the precedents of the old Fifth Circuit. ${ }^{327}$ The Bonner court did initially conclude that proceeding without an established base of precedent was "at best unappealing, at worse catastrophic." ${ }^{328}$ But the most important reason for departing from the general rule was to serve concerns of

322. See Fifth Circuit Court of Appeals Reorganization Act of 1980, Pub. L. No. 96-452, 94 Stat. 1994 (1980) (amending 28 U.S.C. $\$ 41$ ).

323. See supra notes 17-18 and accompanying text.So, unlike the Eleventh Circuit, the Federal Circuit avoided the issue of whether to follow later-decided precedents of a predecessor court. $C f$. Bonner v. City of Prichard, 661 F.2d 1206, 1209 n.5 (11th Cir. 1981) (en banc) (reserving for future consideration the effect on Eleventh Circuit decisions of "future en banc decisions by the old Fifth changing what appeared to have been its rule as of September 30, 1981"). The Eleventh Circuit later concluded that such decisions "are only persuasive, however, not binding precedent in the Eleventh Circuit." See Stein v. Reynolds Sec., Inc., 667 F.2d 33, 34 (11th Cir. 1982).

324. Bonner, 661 F.2d at 1207, 1209; South Corp. v. United States, 690 F.2d 1368, 1369 (Fed. Cir. 1982).

325. See Bonner, 661 F.2d at 1209; South Corp., 690 F.2d at 1369-71.

326. Although South came down almost a year after Bonner, the South court did not refer to the Eleventh Circuit's reasoning in Bonner.

327. See Bonner, 661 F.2d at 1209; see also Marcus, supra note 215, at 686-87 (Because "no court of appeals is bound to respect the decision of another on an issue of federal law . . the Eleventh Circuit had to act affirmatively to adopt Fifth Circuit precedent, which otherwise would not have been binding.") (footnotes omitted).

328. Bonner, 661 F.2d at 1211. 
stability and predictability, "essential factors in the proper operation of the rule of law." ${ }^{329}$ The court noted that the caselaw of the old Fifth Circuit had applied since 1866 to the residents of Alabama, Florida, and Georgia, and thus "the Bench and bar are schooled in it. Citizens of these states and their legal advisers have relied upon it and structured their legal relationships with one another and conducted their affairs in accordance with it"; by adopting this body of law as precedent "we maintain the stability and predictability previously enjoyed." 330

Likewise, in South Corp. v. United States the Federal Circuit chose, for similar reasons, to adopt as binding precedent the decisions of its two predecessor courts. ${ }^{331}$ As in Bonner, the South court rejected the idea of proceeding without a body of precedent. ${ }^{332}$ The court then concluded that the decisions of its predecessor courts, having existed for "a combined total of 199 years" were best suited to its new jurisdiction:

The adoption of precedents here announced continues the stability in those areas of the law previously within the jurisdiction of our predecessor courts .... The public and the bar have presumably structured their legal affairs in accordance with that jurisprudence. To abandon it at this stage would be to cast the court, the public, and the bar adrift on a sea of uncertainty. ${ }^{333}$

Comparing this rationale to the issues posed by RCCOA jurisdiction over patent counterclaims largely supports the merits of deference to the Federal Circuit. Admittedly, one could plausibly distinguish predecessor court deference. The RCCOAs do not have the sequential, almost daughter-parent relationship to the Federal Circuit present in the above scenarios. ${ }^{334}$ In the examples discussed above, moreover, the problem of trying to follow the simultaneouslydeveloping precedents of another court (an important issue with deference to the Federal Circuit) was either not presented or was eliminated. ${ }^{335}$ Finally, the Federal Circuit has not been in existence as long as any of the predecessor courts mentioned above.

But the fact that the RCCOAs enjoy a sibling, ${ }^{336}$ rather than parent-daughter, relationship with the Federal Circuit seems irrelevant; the rule of no deference presumes equal competence and relies on the benefits of intercircuit independence. Nothing in these underlying principles depends on the prior relationship

329. Id. at 1209-10.

330. Id. at 1210 .

331. 690 F.2d 1368, 1370 (Fed. Cir. 1982).

332. Id.

333. Id. at 1371.

334. Cf. Schaffner, supra note 219, at $195 \&$ n. 148 (distinguishing the Federal Circuit's deference to RCCOA precedent from the Eleventh Circuit's deference to the old Fifth Circuit's precedent by noting that the "Eleventh Circuit had been part of the original Fifth Circuit ... and thus did not have a 'sibling' relationship with it at that time").

335. See supra notes 322-23.

336. See supra note 334. 
of two courts. In fact, predecessor-court deference is not a foregone conclusion-at least one newly-formed court of appeals since the Evarts Act's enactment has not chosen to exercise it. ${ }^{337}$

Perhaps more important, patent litigants have assumed for at least a decade that all patent issues produced by claims - whether brought by a plaintiff or a defendant - would be governed by Federal Circuit law. ${ }^{338}$ And for the rapidlydeveloping industries most affected by patent law, industries in which the lifespan of a product is often measured in years, if not months, a decade is a lifetime. Without question, patent litigants have, over that period, become familiar with Federal Circuit law and accustomed to its application; they have "structured their legal relationships ... and conducted their affairs in accordance with it." 339

Similar interests of reliance greatly contributed to the decisions to defer to the precedents of predecessor courts in the examples described above. Those similarities help to illustrate why, in the wake of Vornado, the Federal Circuit has effectively become the predecessor court on patent issues for the RCCOAs. And although deferring to ever-developing Federal Circuit precedents on patent issues will not be easy, there is no reason to think it impractical. In fact, doing so will ensure that the periodic changes in patent rules created by new Federal Circuit cases affect all litigants uniformly.

\section{SUMMARY}

The foregoing discussion shows how deference to the Federal Circuit, consistent with the legal principles concerning deference to coordinate federal courts, will, at the very least, minimize the issues created by Vornado and effectuate congressional intent until a long-term solution is implemented. Moreover, the examples given above provide only three analogous exceptions to the rule of no deference; there are arguably more. ${ }^{340}$

337. The Tenth Circuit, formed by the division of the old Eighth Circuit into the new Eighth Circuit and the Tenth Circuit in 1929, has not chosen to defer to the precedents of its predecessor court. See Estate of McMorris v. Comm'r of Internal Revenue, 243 F.3d 1254, 1258 (10th Cir. 2001) ("[U]nlike the Eleventh Circuit ... we have never held that the decisions of our predecessor circuit are controlling in this court.") (citing Bonner, 661 F.2d at 1209).

338. See supra note 98 and accompanying text.

339. Bonner, 661 F.2d at 1210.

340. For example, the Eighth Circuit has found that the interest in federal law uniformity justifies deference to a coordinate circuit's interpretation of federal law "wherever reasoned analysis will allow, thus avoiding unnecessary burdens on the Supreme Court docket." United States v. Auginash, 266 F.3d 781, 784 (8th Cir. 2001) (citing Aldens, Inc. v. Miller, 610 F.2d 538, 541 (8th Cir. 1979)). That circuit has found the case for deference particularly strong where federal statutes are explicitly intended to have uniform national application. See Nat'l Indep. Meat Packers Ass'n v. EPA, 566 F.2d 41, 43 (8th Cir. 1977) ("The interest in avoiding inter-circuit conflicts is especially strong when the potentially conflicting decisions would present different interpretations of federal law intended to be uniformly applied on a nationwide scale."); see also Kevin E. Balfe, Comment, Factors, Etc., Inc. v. Pro Arts Inc., 10 Hofstra L. Rev. 927, 934 (1982) (the "Eighth Circuit has been particularly enthusiastic in its deference to sister circuits on questions it considers peculiarly deserving of national uniformity"). 
But there is also a larger point here. Whatever the merits of the analogies made above, those who oppose deference to the Federal Circuit cannot simply retreat to the argument that deference to a coordinate court is unprecedented (or almost so) to justify their opposition. Rather, this question should be decided on the reasons for deferring or not in this particular, limited context. Those who would argue against deference should do so on those terms - on the merits of the issue-without blindly retreating to the traditional, and distinguishable, justifications.

\section{Determining the ApPropriate SCope and LeVel of Deference to the Federal Circuit}

Having explored the reasons favoring RCCOA deference to the Federal Circuit in deciding patent counterclaims, it is now appropriate to examine what the scope and level of that deference should be. Part IV.A addresses the appropriate scope of deference, or the type of issues for which the Federal Circuit should be accorded deference. Part IV.B addresses the appropriate level of deference, or the degree or kind of deference the Federal Circuit should be given. This Part's broad conclusion is that when RCCOAs are presented with patent issues raised by patent counterclaims and defenses thereto, they should conditionally defer to the decisional law of the Federal Circuit where applicable. Federal district courts, however, should unconditionally defer to applicable Federal Circuit caselaw.

\section{A. APPROPRIATE SCOPE OF DEFERENCE}

The discussion in Part III broadly referred to deference to the Federal Circuit on patent issues produced by patent counterclaims-the full scope of issues that Vornado removed from Federal Circuit control. This section more fully examines for what issues produced by what claims deference to the Federal Circuit is truly appropriate. It concludes that deference to the Federal Circuit should include all patent issues stemming from patent counterclaims and defenses thereto, but not patent issues, such as patent defenses, stemming from nonpatent claims. The scope of patent issues initially includes those issues that the Federal Circuit considers patent issues.

\section{What Claims?}

Deference should be limited to patent claims that Vornado removed as an independent ground of $\S 1338$ federal question jurisdiction-and thus Federal Circuit appellate jurisdiction - but that would have been claims "arising under" patent law had they been presented in the complaint. This test most clearly includes patent counterclaims, the subject of Vornado. It also includes certain other patent claims, including permissive third-party claims and cross-claims. For ease of reference, and also because counterclaims appear to be far more common, such claims will be collectively referred to as "patent counterclaims." 
RCCOAs should not, however, automatically defer to the Federal Circuit on patent issues stemming from nonpatent federal claims, such as patent defenses to those nonpatent claims. For one thing, Congress did not intend that Federal Circuit caselaw control the adjudication of patent issues in every context they appeared; rather, it seems that Congress only intended Federal Circuit law to control patent issues when produced by patent claims, whether as complaints or counterclaims. ${ }^{341}$ More significantly, applying Federal Circuit law to such patent issues implicates the interests of the plaintiff as master of his claim in choosing the law by which the merits of his nonpatent claim will be decided, and does so in a manner absent when the patent issue is related to a patent counterclaim. To the extent that there is a possibility that deference to Federal Circuit precedents on these patent issues will interfere with RCCOAs' interpretations of other areas of federal nonpatent law, having RCCOAs give Federal Circuit precedents substantial consideration seems more appropriate than an across-the-board rule of deference. Furthermore, the number of cases that include patent defenses to nonpatent claims appears to be relatively small. ${ }^{342}$

\section{What Issues?}

The patent issues subject to deference should include, at least initially, all those issues that the Federal Circuit itself treats as patent issues; that is, those issues relating to patent law for which the Federal Circuit would apply its own precedents if it had jurisdiction. Consequently, this rule initially ties the RCCOA choice-of-law rules on patent counterclaims to those of the Federal Circuit. As discussed above in Part III.c.1, the Federal Circuit's current choice-of-law rules dictate that it apply its own law to substantive issues of patent law, and that it "generally" apply the law of the circuit in which the district court sits to nonpatent issues-although it occasionally will apply its own law to claims for which there is no independent Federal Circuit jurisdiction. ${ }^{343}$

As can be imagined, the scope of what the Federal Circuit considers a patent issue has been the subject of some criticism. A focus of that criticism has been the court's application of its own law to "issues that are peripheral to a straight construction of Title 35 [the patents title of the U.S. Code]," ${ }^{344}$ and, particularly, to certain patent-related issues of antitrust law. ${ }^{345}$ Professor Dreyfuss, noting the basic rule of no deference, has criticized the court for creating a choice-of-law jurisprudence that while "not illogical," is nevertheless "almost unique in

341. See supra Parts I.D.1 and 2 discussing congressional intent as to the Federal Circuit's jurisdiction.

342. Cf. Donofrio \& Donovan, supra note 46, at 1866-67 (there is "little indication that regional circuits have addressed the matter" of whether to apply Federal Circuit law to patent issues before them).

343. See Midwest Indus. v. Karavan Trailers, Inc., 175 F.3d 1356, 1359 (Fed. Cir. 1999).

344. Taylor, supra note 4, at 34 .

345. Id. at 34-35; see generally Ronald S. Katz \& Adam J. Safer, Should One Patent Court Be Making Antitrust Law for the Whole Country?, 69 ANTITRust L.J. 687 (2002). 
federal jurisprudence" and "objectionable from several perspectives." ${ }^{346}$ Dreyfuss argued that the Federal Circuit should retain the ability to independently decide far more of the substantive and procedural issues presented in the cases under its jurisdiction. ${ }^{347}$ Still another commentator has criticized the court for not going far enough in applying its law to substantive issues, but too far in applying its law to procedural ones. ${ }^{348}$

Given the number and variety of criticisms of the Federal Circuit's choice-oflaw jurisprudence, and considering the number of issues outside of substantive patent law to which the Federal Circuit has decided to apply its own law, this Article will not attempt an issue-by-issue determination of the issues for which deference to Federal Circuit precedents is inappropriate. Besides, there are significant benefits in having other courts apply the same rules used by the Federal Circuit as a starting point. For instance, it would be more convenient for both litigants and courts to assume up front that Federal Circuit law will govern a patent counterclaim in the same manner that it would a patent claim presented in the complaint. Moreover, this initial scope of deference would serve the overriding congressional goal of uniformity in this area. ${ }^{349}$

The goal of a uniform patent jurisprudence does not, however, require that RCCOAs blindly accept the Federal Circuit's threshold determination of what questions should be treated as "patent issues." Although it makes sense for that definition to be uniform as a starting point, RCCOAs should subsequently be allowed to disagree with the Federal Circuit when it too broadly defines what is an issue of patent law. Accordingly, the level of deference that this Article suggests the Federal Circuit be given - which is explained in much more detail below-will allow RCCOAs to refuse to apply Federal Circuit law when they believe it is clearly incorrect, thereby providing some safeguard against jurisprudential creep by that court. And as always, the Supreme Court's ability to overrule the Federal Circuit on any issue provides another safeguard, though likely a small one.

\section{B. DETERMINING THE APPROPRIATE LEVEL OF DEFERENCE}

Determining the appropriate level of deference is in many ways more complicated than determining its proper scope, and may not be as amenable to judicial resolution. ${ }^{350}$ Nevertheless, the obvious places to look initially for guidance on

346. Dreyfuss, supra note 25 , at 38 .

347. See id. at 38-46. As this comment was made before much of the Federal Circuit's expansion of the issues to which it would apply its own law, the extent to which Professor Dreyfuss would still advocate such expansion is unclear.

348. See Schaffner, supra note 219, at 1179, 1191-1206.

349. Cf. Donofrio \& Donovan, supra note 46 , at 1867 n.207 (arguing generally that the congressional goal of unifying patent law "can best be achieved if regional circuit courts apply the Federal Circuit's precedent in substantive areas of the law over which the Federal Circuit has exclusive jurisdiction").

350. See, e.g., infra Part V.B (discussing why congressional involvement in setting rules of deference might be useful). 
the appropriate level of deference in the present context are the levels of deference used in the exceptions to the rule of no deference discussed above. Analysis of these exceptions demonstrates why conditional deference to the Federal Circuit by RCCOAs appropriately balances the relevant concerns and why RCCOAs should independently decide questions that are unresolved by Federal Circuit caselaw.

\section{A Choice: Conditional or Unconditional Deference}

Each of the three exceptions to the rule of no deference described above utilized a different level of deference, but one that can generally be classified as either unconditional or conditional. ${ }^{351}$ The Federal Circuit applies what might be called unconditional deference to the relevant RCCOA on nonpatent issues; that is, it does not exercise any independent judgment over nonpatent questions for which RCCOA precedent is available. ${ }^{352}$ For open, nonpatent questions, it will only attempt to predict what the relevant RCCOA would do. ${ }^{353}$ In contrast, the "home circuit" rule is a more conditional deference. Under the rule a court will generally defer even without finding the home circuit's reasoning persuasive, but can disagree with the home circuit's interpretations if they clearly misread state law or are invalid in view of later developments. ${ }^{354}$ For open questions, there is no deference at all under the "home circuit" rule; the deciding court does not appear to try to predict what the RCCOA would have done. ${ }^{355}$ Finally, the deference to a predecessor court doctrine appears to apply

351. Each of the exceptions to the rule of no deference discussed here utilized a different scope of deference as well, which is to be expected because each dealt with a different type of problem.

352. See, e.g., Slip Track Sys., Inc. v. Metal-Lite, Inc., 304 F.3d 1256, 1262 (Fed. Cir. 2002) (applying Ninth Circuit precedent on the standard of review for collateral estoppel determinations and on a district court's denial of a request to modify a pre-trial order, without consideration of that precedent's persuasiveness).

353. See, e.g., Kohus v. Toys R Us, Inc., 282 F.3d 1355, 1358-61 (attempting to predict Sixth Circuit law on the question of whether the costs of video exhibits used at trial were taxable to the losing party under 28 U.S.C. $\S 1920$ by reference to Supreme Court precedent, factually similar decisions of other RCCOAs, and analogous Sixth Circuit decisions).

354. See, e.g., Indep. Petrochem. Corp. v. Aetna Cas. \& Sur. Co., 944 F.2d 940, 944-45 (D.C. Cir. 1991) (professing adherence to the "home circuit" rule generally, but declining to follow the particular local circuit precedent at issue because it "ignored clear signals emanating from the state courts" or "clearly misread state law") (quoting Abex Corp. v. Md. Cas. Co., 790 F.2d 119, 125-26 (D.C. Cir. 1986)).

355. See, e.g., Eli Lilly \& Co. v. Home Ins. Co., 764 F.2d 876, 883 (D.C. Cir. 1985) (attempting to resolve a difficult question of Indiana law-a question the court eventually certified to the Indiana Supreme Court - without attempting to predict how the Seventh Circuit would have predicted Indiana law). This result would seem inherent in the rule itself. The benefits of the "home circuit" rule stem largely from the elimination of any potential conflict with the decisions of the circuit more familiar with a state's law. But on questions that are open both under state law and the precedents of the home circuit, there is nothing to defer to; what benefits the rule has would simply dissipate if a non-local circuit had to predict how the local circuit would predict how the State supreme court would decide an issue of state law. Further, it is doubtful that the non-local circuit can meaningfully benefit from the local circuit's general familiarity with state law when the local circuit itself has not made a reasoned inquiry into state law as to a particular issue. 
conditional deference, but with a procedural component. That doctrine requires a special convening of the deciding court (an en banc sitting) to overrule the predecessor court, but once so convened only the principle of stare decisis would appear to require adherence to the predecessor court's decision. ${ }^{356}$

On one hand, complete deference to the Federal Circuit on patent issues arising from patent claims seems a clear way to effectuate congressional intent. Reflexively applying the precedents of the Federal Circuit to every patent issue (as determined by Federal Circuit caselaw) stemming from a patent counterclaim would undeniably produce uniformity in patent law and reduce patentbased forum shopping.

On the other hand, many of the reasons behind the rule of no deference-and that are cited in the criticisms of the Federal Circuit's blind deference to RCCOAs on nonpatent issues ${ }^{357}$-militate against a rule of complete deference to that court. Arguably, the history of independent judgment by federal courts on issues of federal law is too long, and the merits of the no deference rule too weighty to countenance having an RCCOA defer to a coordinate circuit when, for example, that RCCOA thinks the coordinate circuit's law on an issue is clearly misguided. In addition, complete deference to the Federal Circuit bears the risk of enshrining that court's decisions about what constitutes a "patent issue" in ways that go beyond what congressional intent respecting patent law would require.

It is also difficult to fit the idea that a federal court should independently determine the best answer to open questions-a conclusion reached belowwith a rule of complete deference. Once a court has determined that it is to follow another court's existing decisions in an area without question, the logical next step is to predict what that other court would do on questions with which it has not yet dealt-not to independently determine the "correct" answer. Furthermore, while the reasons for predecessor court deference support the general idea of deference to the Federal Circuit, the burdens that particular procedure would impose on a court-including the requirement of en banc sittings whenever an RCCOA wanted to deviate from a clearly incorrect decision of the Federal Circuit-are probably, given the limited number of cases involved, too high to warrant further consideration.

Rather, a level of conditional deference akin to the "home circuit" rule seems most appropriate. RCCOAs should defer to the established decisional law of the Federal Circuit when applicable unless they believe that a rule of the Federal Circuit is clearly incorrect, such as if the Federal Circuit has misread or ignored

356. While stare decisis is not typically considered a form of deference, it seems accurate to consider it such when applied to another court's precedent. Cf. Ernest A. Young, Judicial Activism and Conservative Politics, 73 U. Colo. L. Rev. 1139, 1151 (2002) (stating that a court which disregards its binding precedent effectively "refuses to defer to prior courts which have considered the same issue"). Moreover, it is properly considered a conditional form of deference because the later court will follow the decision of the predecessor courts unless the policies for not adhering to stare decisis apply.

357. See supra notes $344-48$ and accompanying text. 
a decision of the Supreme Court. To paraphrase the D.C. Circuit's justification of the "home circuit" rule in Abex: Absent situations where the Federal Circuit precedent has been clearly invalidated by later developments (for example, an intervening Supreme Court ruling or an amendment to patent statutes), only when an RCCOA is certain that the Federal Circuit has "clearly misread" a patent statute or otherwise clearly misinterpreted an issue of patent law-such as by "ignor[ing] clear signals emanating from" the Supreme Court- "would it make sense to reject that circuit's view of [patent law]."358

A possible example of "ignoring clear signals" can be found in the other (more well-known) patent case the Supreme Court decided in the 2001 Term, Festo Corp. v. Shoketsu Kinzoku Kogyo Kabushiki Co ${ }^{359}$ In Festo, the Supreme Court unanimously reversed a Federal Circuit decision that imposed a newand retroactive-rule regarding patent infringement under the doctrine of equivalents. ${ }^{360}$ In doing so, the Court concluded that the Federal Circuit had "ignored the guidance of [a prior Supreme Court decision on the subject], which instructed that courts must be cautious before adopting changes that disrupt the settled expectations of the inventing community." 361 The plethora of scholarly commentary criticizing the Federal Circuit's decision in Festo ${ }^{362}$ indicates that it may exemplify the sort of situation in which an appellate court could decide that deference to the Federal Circuit was not justified, and thus be free to devise a better rule.

As with the "home circuit" rule, in only rare situations should a court find the Federal Circuit to have clearly ignored Supreme Court precedents, or otherwise to be plainly incorrect. In fact, to effectuate Congress's goals of uniformity in patent law and the prevention of patent-based forum shopping, such deviations must be infrequent. Such rarity will be aided if only RCCOAs are allowed to depart from applicable Federal Circuit patent precedents; federal district courts should be required by their RCCOAs to give the Federal Circuit's patent precedents conclusive deference until new RCCOA decisions that conflict with such patent precedents, or address issues the Federal Circuit has yet to resolve, are handed down. This approach is also consistent with the inability of district

358. See Abex, 790 F.2d at 125-26; supra note 305 and accompanying text. Note that unlike the "home circuit" rule situation, ignoring clear signals from the Supreme Court is not the predominant justification for not deferring to the Federal Circuit absent a change in the underlying statutes. While the Federal Circuit shares the burden of any appellate court of trying to be faithful to the Supreme Court's interpretations of federal law, it is in a different jurisprudential stance than a federal court trying to predict an open issue of state law consistent with the signals offered by that state's highest court. See supra note 303. In particular, the Federal Circuit has the ability to independently analyze issues of patent law not controlled by Supreme Court precedent without trying to predict how the higher Court will resolve them. An RCCOA could, therefore, find the Federal Circuit's interpretation of patent law clearly incorrect without deciding that the Federal Circuit had ignored Supreme Court precedent.

359. 535 U.S. 722 (2002).

360. See Id. at 738-39.

361. Id. at 739. (emphasis added).

362. See, e.g., Jonathan M. Harris, Festo Has Decimated the Doctrine of Equivalents, 65 TEx. B.J. 58 (2002). 
courts to overrule the "law of the circuit," and avoids any confusion about which circuit's law applies at the trial level.

Practical considerations also influence the choice of deference level. In particular, appellate judges may be more than willing to defer to the experience of the Federal Circuit on most patent issues-in fact, before the creation of the Federal Circuit, the displeasure of some judges at having to address patent issues at all did not go unnoticed. ${ }^{363}$ But appellate judges may be inclined to resist deference when they are convinced that the Federal Circuit has reached a clearly incorrect conclusion. Conditional deference accommodates that inclination.

\section{Dealing with Open Questions}

A final issue relates to the treatment of questions that are open or unsettled under Federal Circuit precedents. If, for example, the Federal Circuit has never ruled on an issue, then there is no precedent for the RCCOA to defer to. In rare cases, the Federal Circuit's law on a particular issue may simply be too unclear to apply. ${ }^{364} \mathrm{~A}$ similar problem arises with issues over which there is arguably a conflict within the Federal Circuit-such as when one panel has ruled differently on an issue than a previous one, without overruling the previous panel. This is not entirely uncommon, despite the court's conflict-prevention mechanisms. ${ }^{365}$

As implied above, patent law-and perhaps any other area of law where Congress has conferred almost exclusive appellate jurisdiction over a subject matter to a single court-is an area where uniformity in the law is generally a more important goal than that of independent development of the law as embodied by the rule of no deference. But uniformity concerns are arguably at a nadir for issues on which the Federal Circuit has not ruled or over which its panels are in conflict; in these situations, the calculus that justifies deference in the first place is significantly altered. There is, admittedly, a possibility that an RCCOA's prediction of how the Federal Circuit would address an open issue would be more in line with overriding trends in Federal Circuit precedents than would its independent decision, thereby serving the interests of uniformity. To be sure, such an approach would simply mirror what the Federal Circuit itself does when faced with an open nonpatent question-try to predict how the relevant regional court would decide the issue.

Given the attenuated uniformity concerns presented by truly open questions,

363. See Dreyfuss, supra note 25 , at $7 \mathrm{n} .47$ (noting that at one congressional hearing regarding the creation of the Federal Circuit "it was opined that patents were 'the most unattractive thing about being a Federal judge'") (quoting Court of Appeals for the Federal Circuit: Hearings Before the Subcomm. on Courts, Civil Liberties and the Administration of Justice of the House Comm. on the Judiciary, 97th Cong., 1st Sess., at 46 (1981)).

364. Cf. Mars Inc. v. Kabushiki-Kaisha Nippon Conlux, 24 F.3d 1368, 1371 (Fed. Cir. 1994) (showing that even the Federal Circuit only defers to the "discernable law of the regional circuit in which the district court sits") (emphasis added).

365. See Conflicts in Federal Circuit Patent Law Decisions, 11 Fed. CIR. B.J. 723 (2001) (listing several areas where there is an arguable conflict between panel decisions on an issue). 
the reasons underlying the principle of competency seem even weightier. Consequently, the rule of no deference should again prevail, allowing RCCOAs to reach their own view of what is "best" on those issues. This would allow for independent development of the law by RCCOAs on the issues of patent law most deserving of Supreme Court review, such as novel questions of patent law and those issues on which the Federal Circuit itself cannot agree. ${ }^{366}$

There is a practical consideration here as well: This level of deference on an open issue will more likely comport with the instincts of RCCOA judges. Quite apart from the issue of treating the precedents of another court as binding, RCCOA judges may more strongly resist the idea of having to predict what another federal appellate court would do with an unresolved issue-an aspect of deference that appears unique to the Federal Circuit's own choice-of-law jurisprudence. ${ }^{367}$

\section{SUMMARY}

The above discussion merely represents an initial examination of the appropriate scope and level of deference by RCCOAs in this context. It leaves open the possibility of further analysis showing that unconditional deference to the Federal Circuit is most appropriate, regardless of the concerns addressed above. This conclusion might, for example, hold true if the deference analysis could be logically subdivided in some manner allowing for different levels of deference in different situations. For example, the case for RCCOA deviation from Federal Circuit caselaw is weaker on the narrower question of an issue created by and involving the interpretation of a provision within Title 35. In that case, only a small risk exists that the application of Federal Circuit precedents will improperly expand the areas of law that Congress intended that court's jurisprudence to control.

In contrast, whether a particular counterclaim arises under patent law at all (i.e., is a patent counterclaim) might be an issue for which RCCOAs are more easily justified in deviating from relevant Federal Circuit precedents-and perhaps in refusing to defer altogether. ${ }^{368}$ On that threshold issue, RCCOAs

366. A viable alternative here might be legislation allowing certification of open patent issues by RCCOAs to the Federal Circuit, just as some states allow federal courts to certify unsettled state law issues to the state's highest court. See Howard J. Bashman, A Federal Journey into the Unknown of State Law, The Legal InTElligencer, Mar. 10, 2003, at 5 (discussing advantages and disadvantages of certifying issues of state law). However, further study of the benefits and disadvantages of this option in the particular context of patent law and certification to a coordinate federal court is necessary before such an option can be recommended.

367. For example, neither the "home circuit" rule nor the deference to a predecessor court exceptions appears to require such deference.

368. See, e.g., Shaw v. Gwatney, 795 F.2d 1351, 1353 n.2 (8th Cir. 1986) (denying that the Federal Circuit had complete power to determine the existence of $\S 1295$ appellate jurisdiction and concluding that allowing it to do so would "subordinate a regional circuit to the Federal Circuit with regard to such traditional and inherent functions as determining its own jurisdiction and supervising the exercise of jurisdiction by the district courts below it"). 
need some ability to ensure that the Federal Circuit is not classifying certain claims as patent claims, when they clearly are not.

In any event, deference to the Federal Circuit as described above can be voluntarily implemented by courts. RCCOAs should not let a fear that the rule of no deference is an unchangeable legal requirement prevent adoption of the choice-of-law rule that this Article proposes, though other circuit-specific requirements may have to be addressed. ${ }^{369}$ As the choice-of-law exceptions discussed above in Part III.B demonstrate, there is no absolute bar against deference by federal appellate courts to coordinate courts. And with respect to any complaints about the particular form of deference this Article recommends, it should not be forgotten that the Federal Circuit itself has, over its twenty-plus years of existence, implemented an even broader form of deference.

\section{Avoiding the False Choice: Deference as a Long-Term SOLUTION AND OTHER ISSUES}

Now that the case for deference to the Federal Circuit as a short-term solution to post-Vornado problems has been discussed, it is appropriate to analyze the merits of deference as a long-term solution to those problems. In terms of effectuating congressional intent as well as securing other policy benefits, there is no reason to think that the reasons militating in favor of deference in the short-term do not apply to the long-term as well. But still, one might ask, if it appears that Congress's intent was to give the Federal Circuit exclusive jurisdiction over all cases with a patent claim, why not just amend the relevant jurisdictional statutes to that effect?

As Part V.A explains, there are several reasons why deference to the Federal Circuit is superior in the long term to jurisdictional modifications that would allow exclusive Federal Circuit jurisdiction to be created by a patent counterclaim, thus divesting the nonpatent plaintiff of her choice of appellate forum. After the merits of deference as a long-term solution have been analyzed, Part V.B examines options for implementing such deference. Part V.c then briefly looks at the potential state court issues presented by Vornado.

\section{A. PRESERVING UNIFORMITY IN PATENT LAW AND THE PLAINTIFF'S CHOICE OF FORUM THROUGH DEFERENCE TO THE FEDERAL CIRCUIT}

The primary benefit of deference over approaches expanding the Federal Circuit's jurisdiction is that deference would further the congressional goals of

369. For example, the old patent decisions of the RCCOAs, if not overruled by the Supreme Court or obviated by changes in the patent statutes, are still the "law of the circuit." See, e.g., Hart v. Massanari, 266 F.3d 1155, 1171 (9th Cir. 2001) ("[T]he first panel to consider an issue sets the law not only for all the inferior courts in the circuit, but also future panels of the court of appeals."). Thus, those circuits that do not allow individual panels to overrule the law of the circuit may need to sit en banc to adopt a rule of deference to the Federal Circuit (both for conditional deference by RCCOAs and for unconditional deference by district courts), as such adoption would overrule those prior decisions in situations where they conflict with Federal Circuit precedents. 
uniformity in patent jurisprudence and the avoidance of patent-based forum shopping without unnecessarily impinging on a fundamental principle of federal question jurisdiction: the plaintiff as master of his claim, which includes the plaintiff's interest in preserving his choice of appellate forum. Several approaches amending the relevant jurisdictional statutes have been investigated or proposed in response to Vornado; three possibilities for jurisdictional amendment will be discussed in more detail below. All three approaches attempt to resolve the problems created by Vornado by allowing patent counterclaims to shift appeals of cases in which the plaintiff has brought no patent claim from an RCCOA - to which the appeal would normally go post-Vornado- to the Federal Circuit. Whether stated expressly or implied, these proposals are predicated on the belief that, when a patent counterclaim is raised, interests of uniformity, the prevention forum shopping, and other concerns require rejecting the policies behind the well-pleaded complaint rule and necessitate divesting the plaintiff of his chosen appellate forum. But that is a false choice, and this section aims to discredit its underlying assumptions.

One jurisdictional approach would be a statutory amendment giving the Federal Circuit jurisdiction over any case in which a patent claim was "actually adjudicated," along the lines of Justice Ginsburg's opinion in Vornado. ${ }^{370}$ Such an approach, however, can be easily rejected for the reasons discussed in Part I.D.4.

The other two jurisdictional approaches have more merit. One approach would be simply to restore the Federal Circuit's jurisdiction to its pre-Vornado scope by amending $\S 1338$ to provide district courts with jurisdiction over any claim "arising under" patent law. ${ }^{371}$ As noted in Part I.D.3, this type of approach would violate the well-pleaded complaint rule and run counter to the fundamental policies behind it, particularly, the plaintiff as master of his claim. The Vornado Court explained that it has long been the law that a plaintiff who has only state claims and chooses to file in state court cannot be forced into federal court by the defendant raising a federal issue or claim. But if $\S 1338$ jurisdiction were extended to include all patent claims, this would, absent a change to the removal statute, no longer be true. It seems undisputable that, if patent-law uniformity can be preserved without upsetting the basic balance represented in our established rules of federal question jurisdiction, it should be. Deference to the Federal Circuit can do just that.

Admittedly, Molly Mosley-Goren's more nuanced jurisdictional proposal would also take such policies into account. Her proposal would change $§ 1338$

370. See supra notes $136-140$ and accompanying text.

371. See Report of the Ad Hoc Committee, supra note 258, at 719. The Ad Hoc Committee's Report, however, also allowed for the possibility of "an additional, prophylactic amendment" of the removal statute-a change that Mosley-Goren, a member of the Committee, affirmatively recommended in her separate article, see supra notes 372-73 and accompanying text-if concerns became serious about its proposed amendment to $\$ 1338$ expanding the district courts' removal jurisdiction. See Report of the Ad Hoc Committee, supra note 258 , at $727-28$. 
to ensure that district courts have exclusive jurisdiction over any case with a patent claim, but also would amend the removal statute to prevent removal of a case from state court based on the presence of a patent counterclaim. ${ }^{372}$ Mosley-Goren persuasively explains the benefits of such an approach over a broader amendment, which include avoiding a "glut of removable cases," and dismisses the effect of such a solution on the plaintiff's choice of appellate forum. ${ }^{373}$

Unfortunately, even this approach does not sufficiently preserve the plaintiff's choice-of-forum interest that the well-pleaded complaint rule aims to protect. Justice Stevens's separate opinion in Vornado accurately recognizes that the choice-of-forum interest underlying the policy of leaving the plaintiff as "master of the claim" was not limited to a choice between state and federal systems, but extended to the plaintiff's "legitimate interest" in his choice of appellate forum as well. ${ }^{374}$ So a plaintiff who files his suit in, for example, the Northern District of Georgia necessarily chooses the Eleventh Circuit as the appellate forum, the precedents of which (absent relevant Supreme Court caselaw) will govern the outcome of his claim.

Deference to the Federal Circuit preserves the nonpatent plaintiff's choice of appellate forum for those claims. Moreover, this interest logically only extends to the choice of "law [the plaintiff] will rely upon" for his claims, ${ }^{375}$ not to the law his chosen forum will apply to his adversary's counterclaims. As such, deference to the Federal Circuit retains patent-law uniformity while remaining entirely consistent with "the paramount policies embodied in the well-pleaded complaint rule"--policies that ring no less true in this special context- "that the plaintiff is the master of the complaint, that a federal question [of patent law] must appear on the face of the complaint, and that the plaintiff may, by eschewing claims based on [patent] law, choose to have [the appeal of] the cause heard in [the relevant RCCOA]," and not the Federal Circuit. ${ }^{376}$ In contrast, the interest in allowing the nonpatent plaintiff his choice of appellate forum "would be defeated by a rule that allowed a patent counterclaim to determine the appellate forum," 377 as would Mosley-Goren's proposal.

Of course, the plaintiff's choice of appellate forum is not unfettered. The existence of statutes authorizing a change of venue (which can produce a change in appellate forum $)^{378}$ demonstrates that the interest can be overcome

372. See Mosley-Goren, supra note 12, at 29-30.

373. Id. at $30,47-48$.

374. Holmes Group, Inc. v. Vornado Air Circulation Sys., Inc., 535 U.S. 826, 834 (2002) (Stevens, $\mathrm{J}$. , concurring in part and concurring in the judgment).

375. See The Fair v. Kohler Die \& Specialty Co., 228 U.S. 22, 25 (1913) ("Of course, the party who brings a suit is master to decide what law he will rely upon") (Holmes, J.).

376. Cf. Caterpillar Inc. v. Williams, 482 U.S. 386, 398-99 (1987).

377. Vornado, 535 U.S. at 837 (Stevens, J., concurring in part and concurring in the judgment).

378. See 28 U.S.C. $\$ 1404$ (a) (2000). And in a related context, the Supreme Court has squarely rejected the idea "that plaintiffs may defeat a motion to dismiss on the ground of forum non conveniens merely by showing that the substantive law that would be applied in the alternative forum is less 
with sufficient justification. But when such justification is absent, and when deference will serve the same goals of uniformity and avoidance of forum shopping post-Vornado that jurisdictional approaches aim to address, the plaintiff's interest in his chosen appellate forum should not be disregarded.

Granted, there might not be significant disadvantages in practice to adopting Mosley-Goren's proposal if the Federal Circuit adjudicated plaintiffs' nonpatent claims exactly as would the relevant RCCOA. It is clear, however, that this no longer is the case-if it ever was. As explained above, the Federal Circuit has expanded the application of its own law beyond the literal scope of Title 35, and now "fashion[s] its own substantive liability rules for antitrust, trade dress, and other claims over which it only ha[s] pendent or non-exclusive jurisdiction." ${ }^{379}$ Consequently, allowing defendants to move the appeal of a case into the Federal Circuit can result in a plaintiff's nonpatent claim being adjudicated under a different interpretation of federal law than if jurisdiction had remained in the relevant RCCOA.

Perhaps the most well-known area where such a conflict exists lies in patent-related issues of antitrust law. For example, the Federal Circuit has decided that " $[w]$ hether conduct in procuring or enforcing a patent is sufficient to strip a patentee of its immunity from the antitrust laws is to be decided as a question of Federal Circuit law." ${ }^{380}$ In doing so, it "expressly declined to follow the antitrust law articulated by the Ninth Circuit in [an earlier case that] involved similar facts and antitrust questions." ${ }^{381}$ Another example of such conflicts could have been Vornado itself. Had TrafFix not resolved the split between the Tenth Circuit and the Federal Circuit on an issue of federal trade-dress law, the shift of appellate jurisdiction from the Tenth Circuit to the Federal Circuit through Vornado's filing of a patent counterclaim would have resulted in Holmes's trade-dress declaratory-judgment action being decided under different nonpatent law. ${ }^{382}$

The point here is not to say that the Federal Circuit has made the wrong decision in these cases. Arguably, when that court properly has jurisdiction over a case, its decision that certain issues have such a relation to patent law that the law of the Federal Circuit should apply to them-even though those issues stem from nonpatent claims - may not contravene congressional intent. But if patent counterclaims are allowed to create Federal Circuit jurisdiction, the real and

\footnotetext{
favorable to the plaintiffs than that of the [plaintiffs' chosen] forum," holding that such an argument does not "ordinarily" warrant "even substantial weight in the forum non conveniens inquiry." Piper Aircraft Co. v. Reyno, 454 U.S. 235, 247 (1981), cited in Dreyfuss, supra note 25, at 38 n.220.

379. James W. Dabney, Holmes v. Vornado: A Restatement of the "Arising Under" Jurisdiction of Federal Courts, NBSA BRIGHT IDEAs, Fall 2002, at 3, 5.

380. In re Indep. Serv. Org. Antitrust Litig., 203 F.3d 1322, 1325 (Fed. Cir. 2000) (quoting Nobelpharma AB v. Implant Innovations, Inc., 141 F.3d 1059, 1068 (Fed. Cir. 1998)).

381. Dabney, supra note 379, at 6 (citing Image Tech. Servs., Inc. v. Eastman Kodak Co., 125 F.3d 1195 (9th Cir. 1997)).

382. See supra notes 111,115 and accompanying text.
} 
significant result is that a plaintiff's nonpatent claims will be decided differently than they would have been had his choice of appellate forum been preserved.

More directly related to the congressional purposes behind the Federal Circuit, this possibility could create forum-shopping opportunities for an unscrupulous patentee-defendant. ${ }^{383}$ Although this interest was not mentioned as frequently in the legislative history as was the goal of avoiding forum shopping based on favorable patent law, Congress did not intend the Federal Circuit to create forum-shopping opportunities in nonpatent law either. ${ }^{384}$ So long as the Federal Circuit continues to apply its own law to nonpatent claims within its jurisdiction, deference will do a better job of serving that intent than would any jurisdictional approach.

383. Mosley-Goren recognized the possibility of nonpatent-based forum shopping, but appeared to think that it was more important to resolve patent-based forum shopping. See Mosley-Goren, supra note 12, at 53. Implementation of deference to the Federal Circuit, and the affect that would have on patent-based forum shopping, would have to shift her calculus, though.

384. See S. REP. No. 97-275, at 19-20 (1981), reprinted in 1982 U.S.C.C.A.N. 11, 29-30 ("This measure is intended to alleviate the serious problems of forums [sic] shopping among the regional courts of appeals on patent claims by investing exclusive jurisdiction in one court of appeals. It is not intended to create forum shopping opportunities between the Federal Circuit and the regional courts of appeals on other claims.") (emphasis added). In addition, under a jurisdictional approach, it is possible that certain nonpatent claims would almost always go to the Federal Circuit, because jurisdictioncreating patent counterclaims would almost always be filed in response. Insofar as such nonpatent claims did not themselves create Federal Circuit jurisdiction, this would have the effect of divesting an entire area of nonpatent law from the jurisdiction of the RCCOAs. This is a result that Congress explicitly forbade absent specific authorization. See id. at 4, 1982 U.S.C.C.A.N. at 14 ("It must therefore be noted that any additional subject matter for the [Federal Circuit] will require not only serious future evaluation, but new legislation.").

But Mosley-Goren, like the Federal Circuit before her, see Atari, Inc. v. JS \& A Group, Inc., 747 F.2d 1422, 1437 (Fed. Cir. 1984), overruled on other grounds by, Nobelpharma AB v. Implant Innovations, Inc., 141 F.3d 1059 (Fed. Cir. 1998), attempts to justify a more expansive jurisdiction for the court by referring to Congress's desire that the court not be limited to just hearing appeals of patent claims: "Congress recognized, as expressed in the legislative history of the Federal Circuit's creation, that non-patent claims should be heard by the court. Indeed, Congress intended that the Federal Circuit decide non-patent claims as an amulet protecting against the strongest objection to the court's creation-specialization." Mosley-Goren, supra note 12, at 55 . But there is no evidence in either congressional report for the FCIA that Congress expected the Federal Circuit's supplemental jurisdiction to protect against specialization. Rather, Congress identified the Federal Circuit's primary jurisdiction over appeals from a variety of nonpatent areas as the factor that would insulate it from the problems of specialized courts.

The House Report, for example, noted that

[b]y combining the jurisdiction of the two existing courts along with certain limited grants of new jurisdiction, the bill creates a new intermediate appellate court markedly less specialized than either of its predecessors and provides the judges of the new court with a breadth of jurisdiction that rivals in its variety that of the regional courts of appeals.

H.R. ReP. No. 97-312, at 19. Then, to support this claim, the report listed the variety of issues the new court would handle, none of which includes appeals of the nonpatent claims the court could hear in the course of exercising its jurisdiction over patent appeals. Id. The Senate Report echoed this sentiment. See S. REP. No. 97-275, at 6, 1982 U.S.C.C.A.N. at 16 ("[T] will not be a 'specialized court,' as that term is normally used. . . . It will handle all patent appeals, plus government claims case[s] and all other appellate matters that are now considered by the CCPA or the Court of Claims - cases which contain a wide variety of issues."). 
Some of the difficulties in deciding the best approach here may stem from the fact that some counterclaims are compulsory. If there were no such requirement, it would be much harder to argue that a defendant's choice to interpose his permissive counterclaim in a case should be allowed to divest the plaintiff's choice of forum when the uniformity and other congressional interests behind the Federal Circuit's exclusive jurisdiction could be satisfied through deference. In fact, an appropriate balance of these concerns might be to eliminate the compulsory counterclaim requirement for any claim that, if filed in the complaint, would have given the Federal Circuit jurisdiction over the appeal. This would prevent a patentee from being forced to bring his claim in a case that would not be heard by the Federal Circuit, while still allowing permissive patent counterclaims, if filed, to be governed by Federal Circuit caselaw. At a minimum, the existence of deference as a viable possibility seems to significantly weaken the case for expanding of the Federal Circuit's jurisdiction beyond compulsory counterclaims.

In any case, RCCOAs should at least be allowed to retain jurisdiction over these cases initially. Even though Congress may have expected patent counterclaims to create Federal Circuit jurisdiction, Vornado held that, under the jurisdictional language that Congress enacted, they do not. That language should not simply be amended to capture decades-old congressional intent. Rather, a better solution-one that is consistent with the traditional principles underlying statutory federal question jurisdiction and that preserves the Federal Circuit's jurisprudential achievements in the interim-is to defer to the Federal Circuit on patent issues raised by patent counterclaims. Only if it appears that the RCCOAs cannot or will not properly apply Federal Circuit precedents to patent counterclaims does it make sense to reject established principles of federal question jurisdiction.

In the end, Vornado can be seen as almost a blessing in disguise. If the Vornado court had upheld the Aerojet rule (a distinct possibility, as discussed in Part I.D.), the problems recognized above-including the violations of established policies of federal question jurisdiction-would have remained. But those established principles are established for a reason. Though perhaps based more on "history than logic,"385 they likely would not have stood the test of time if they lacked merit. While problematic in the short term, Vornado leaves room for a long-term solution that can preserve uniformity in patent law without contravening these longstanding principles: deference to the Federal Circuit.

\section{B. METHODS OF IMPLEMENTATION}

Even if one agrees that deference to the Federal Circuit not only is appropriate but also is the best long-term solution, the question remains as to how deference can and should be implemented. There are three primary possibilities

385. Franchise Tax Bd. of Cal. v. Construction Laborers Vacation Trust, 463 U.S. 1, 4 (1983). 
for implementation of such deference: congressional enactment, voluntary judicial adoption, and a combination thereof.

\section{Congressional Enactment}

Deference can perhaps most easily be implemented by simple statutory mandate-a quasi-Rules of Decision Act $^{386}$ for patent law-but with sufficient detail dictating the general level of deference in all applicable situations (rather than leaving it for the courts to decide). ${ }^{387}$ It seems logical that Congress, as the source of federal law, would have the power to dictate to lower federal courts how they must interpret that law. A recent essay by Professor John Harrison confirms this intuition. ${ }^{388}$ Although acknowledging that the question of Congress's ability to legislate a federal court's precedential norms is a "largely uncharted field,"389 Harrison concludes that "Congress has substantial authority to legislate concerning the rules of precedent in federal court. . . . . Congress at least may adopt any norm of stare decisis that a court could reasonably could recognize." 390 As the prior discussion demonstrates, not only could a court reasonably recognize the level and scope of deference this Article recommends, but the Federal Circuit has, for almost twenty years, implemented an even broader rule of deference.

The primary advantage of this method of implementation is that it would avoid the possibility of piecemeal adoption of deference, or even no deference at all. Congressional enactment would immediately impose the rule nationwide, which is especially important in addressing concerns about the confusion created by Vornado. But attempting to implement deference by statute alone would have important disadvantages. For example, once Congress has enacted a rule, it is often difficult to get Congress to change it. But as noted above, the complete extent of the deference that RCCOAs should give the Federal Circuit is unclear and complicated. And though it may be possible to derive widely accepted principles for determining such scope of deference on an issue-byissue basis, this task should not, perhaps, be entrusted entirely to Congress. Defining precise rules of judicial precedent or procedure is not its primary area of expertise.

\section{Voluntary Adoption by Federal Courts}

As explained in Part IV.C, RCCOAs could simply adopt deference to the Federal Circuit voluntarily as a choice-of-law rule in relevant cases. This would

386. 28 U.S.C. $\$ 1652$ (2000).

387. Professor Dreyfuss noted in passing the possibility of "requiring the regional circuits (and even state courts) to follow [Federal Circuit patent] law" early in the Federal Circuit's existence, but concluded that it "would create many of the same problems that arose in connection with the application of regional circuit law by the" Federal Circuit. Dreyfuss, supra note 25, at 57 n.294.

388. See John Harrison, The Power of Congress over the Rules of Precedent, 50 DukE L.J. 503 (2000).

389. Id. at 505.

390. Id. at 504 . 
have the benefit of allowing the courts that will actually have to implement any rules of deference to decide on the rules' scope. This is surely an issue for which RCCOAs are competent.

The primary drawback of relying on this mode of adoption is that there is no guarantee that all, or any, RCCOAs will adopt such a rule of deference. And even if they all adopted the general principle, there is no guarantee that they would agree on its full scope. The Supreme Court could, however, step in and dictate nationwide rules on these choice-of-law issues, just as it has done in the Erie context, as well as with issues regarding "law-of-the-case" doctrine. ${ }^{391}$

\section{A Combination of Methods}

But a combination of the two methods may be best. A broad statutory mandate for other inferior federal courts to defer to the Federal Circuit on patent issues arising from patent counterclaims would ensure speedy, nationwide adoption of the general principle of deference. By specifically leaving room for the courts to flesh out the details of this deference, Congress could play to their respective competencies, and preserve future flexibility in determining the principle's contours.

\section{STATE COURT ISSUES POST-VORNADO}

The Vornado decision also raises the apparently unprecedented possibility that state courts will now be able to adjudicate patent counterclaims. This was, in fact, the conclusion reached in dicta by the Supreme Court of Indiana just a few months after Holmes was decided. ${ }^{392}$ While state courts have long been thought to have jurisdiction over patent defenses to state law claims, it has generally been assumed that the policies behind the exclusive jurisdiction of the federal courts over patent claims were sufficient to give federal courts exclusive jurisdiction over patent counterclaims. ${ }^{393}$ But the Indiana Supreme Court in Green concluded that, after Vornado, this was no longer true: "The only basis for concluding that a state court may not entertain patent or copyright counterclaims is the exclusive jurisdiction conferred by section 1338 over 'any civil action arising under' the patent or copyright laws. [Under Vornado, a] counterclaim under those laws does not fall within that language." 394

391. See Christianson v. Colt Indus. Operating Corp., 486 U.S. 800, 819 (1988) ("Under law-of-thecase principles, if the transferee court can find the transfer decision plausible, its jurisdictional inquiry is at an end.").

392. See Green v. Hendrickson Publishers, Inc., 770 N.E.2d 784, 793 (Ind. 2002).

393. See, e.g., Tewarson v. Simon, 750 N.E.2d 176, 183 (Ohio Ct. App. 2001) ("[W]hile federal courts possess supplemental jurisdiction over state-law counterclaims, state courts do not have corresponding authority over claims over which federal courts have exclusive jurisdiction.") (citing Am. Home Prods. Corp. v. Norden Lab., Inc., 1992 WL 368604, at*3 (Del. Ch. Dec. 11, 1992)); Green, 770 N.E.2d at $792 \&$ n. 3 .

394. Green, 770 N.E.2d at 793 . Green did not address the possibility that state courts may lack jurisdiction over patent counterclaims notwithstanding a lack of any explicit statutory bar. $C f$. Tafflin v. Levitt, 493 U.S. 455, 459-60 (1990) (presumption in favor of state court concurrent jurisdiction over 
And although no federal appellate court appears to have squarely considered the question, district court cases post-Vornado addressing the scope of $\S 1338$ support Green's conclusion. These cases seem to uniformly read Vornado as applying the well-pleaded complaint rule to the question of removal in the same way that it applies to the question of original jurisdiction, thus barring removal if the patent claim does not appear in the plaintiff's complaint. ${ }^{395}$ So the net result of these state and federal cases is that state courts may consider themselves able to hear patent counterclaims post-Vornado, and district courts will deny attempts to remove cases based on the presence of a patent counterclaim.

Moreover, state courts also generally follow the rule of no deference with respect to the opinion of lower federal courts. State courts interpreting federal statutes are bound by decisions of the Supreme Court of the United States but not by decisions of lower federal courts-not even those of their own RCCOA. ${ }^{396}$ State courts, however, often use such decisions as persuasive authority. ${ }^{397}$

The freedom of state courts to interpret patent statutes independently of Federal Circuit precedents would seem to raise problems similar to those noted for RCCOAs. But there may be some differences. For example, the state court problems would be worse to some extent because state courts are even more inexperienced than RCCOAs in deciding patent claims. But this lack of inexperience has the corollary benefit of avoiding confusion at the trial level stemming from having to choose between old state patent precedents and newer Federal Circuit ones.

To be sure, the nature of the potential problems in the state and RCCOA

federal law "can be rebutted by an explicit statutory directive, by unmistakable implication from legislative history, or by a clear incompatibility between state-court jurisdiction and federal interests") (quoting Gulf Offshore Co. v. Mobil Oil Corp., 453 U.S. 473, 478 (1981)). Even without reference to the legislative history for $\S 1338$, factors weighing against state court jurisdiction over patent counterclaims might include the long-recognized desirability of uniform federal interpretation of patent law, as well as the significantly greater expertise of federal judges in hearing patent claims-especially as state courts have not been considered competent to hear such claims for over 200 years.

395. See, e.g., Flanders Diamond USA, Inc. v. Nat'l Diamond Syndicate, Inc., 2002 WL 31681474 , at *4 (N.D.Ill. Nov. 27, 2002) ("National's counterclaim, though it is focused directly on Flanders' patent's scope and validity, cannot provide an independent source of 'arising under' jurisdiction.... Because patent law forms no essential element of Flanders' complaint, this Court lacks federal question jurisdiction over the case."); In re Tamoxifen Citrate Antitrust Litig., 222 F. Supp. 2d 326, 330 (E.D.N.Y. 2002) ("[A]nswers and counterclaims cannot serve as the basis for 'arising under' jurisdiction.”); United Mut. Houses, L.P. v. Andujar, 230 F. Supp. 2d 349, 350 (S.D.N.Y. 2002) (“[A] plaintiff is master of the complaint-neither a federal defense nor counterclaim will create removal jurisdiction.").

396. See Robert A. Ragazzo, Transfer and Choice of Federal Law: The Appellate Model, 93 MicH. L. Rev. 703, 742 \& n.254 (1995) ("When a state court decides federal issues, it owes no fealty to the inferior federal courts in its region, including the local court of appeals. State trial courts owe obedience on federal issues only to the higher state courts and the Supreme Court of the United States. This result obtains because the inferior federal courts do not lie in the path of appellate review.") (also collecting cases supporting this point).

397. See, e.g., People v. Estrada, 44 Cal. Rptr. 165, 171 (Dist. Ct. App. 1965) ("[W]e are not bound by the decisions of lower federal courts even on federal questions although they are persuasive and entitled to great weight."). 
contexts seem sufficiently analogous to justify deference by state courts as well.Indeed, on initial inspection, the case for voluntary deference by state courts seems just as clear, if not stronger than that for RCCOAs.In particular, the greater inexperience of state courts in adjudicating patent claims gives those courts more reason to rely on Federal Circuit precedents. Furthermore, the general congressional judgment about state versus federal court competence in patent cases, reflected in $\S 1338$ 's grant of exclusive federal jurisdiction, also points in favor of deference.

But it may be most consistent with the interests long thought to be represented in $\S 1338$ to prevent patent counterclaims from being heard in state courts at all. This could be accomplished by first partially adopting MosleyGoren's proposal, such that patent counterclaims could neither be heard in state courts nor used to remove a case to federal court. ${ }^{398}$ Then, $\S 1295(\mathrm{a})(1)$ could be modified so that the Federal Circuit's exclusive jurisdiction could only be invoked when the district court's jurisdiction was based on the traditional language of "a civil action arising under" patent law. This would limit the Federal Circuit's patent jurisdiction to those cases in which a patent claim appeared on the face of plaintiff's well-pleaded complaint, allowing deference to the Federal Circuit in appeals heard by RCCOAs to effectuate congressional goals while preserving the nonpatent plaintiff's choice of appellate forum.

\section{SUMMARY}

The above discussion demonstrates the superiority of deference to the Federal Circuit over jurisdictional approaches that would, even in their most narrow formulations, unnecessarily divest the plaintiff of his choice of appellate forum. It also explains the variety of ways in which deference as a long-term solution could be implemented, and suggests that a combination of broad congressional action and judicial refinement of the specifics of deference might be ideal. Finally, it examines the issues that Vornado raises in state courts, and notes that, while deference to the Federal Circuit seems feasible, the best solution may be to return to the traditional exclusive jurisdiction of federal courts over all patent claims.

\section{CONCLUSION}

To be sure, this Article does not conclusively resolve all issues surrounding deference to the Federal Circuit; given the complexity of this topic, several issues discussed herein could benefit from further inquiry. As mentioned, for example, at the conclusion of Part IV, it could be particularly useful to explore a more differentiated approach, perhaps based on the type of issue presented, to the question of the level of deference-if any-RCCOAs should accord the Federal Circuit's patent precedents. Even so, this paper's discussion of the

398. See Mosley-Goren, supra note 12, at 29. 
feasibility and merits of deference should amply support judicial implementation of deference in appropriate cases and serve as a sound platform for legislative action and further scholarly investigation.

And however implemented, deference to the Federal Circuit on patent issues raised by patent counterclaims would effectuate Congress's intent in creating the Federal Circuit to produce a uniform patent jurisprudence. Conditional deference by RCCOAs (and unconditional deference by federal district courts) to the Federal Circuit's precedents would have significant advantages as a short-term resolution of the problems Vornado creates. In the long-term, such deference would prevent almost all of the damage to uniformity in patent law potentially caused by Vornado, while preserving the interests behind the wellpleaded complaint rule - and in particular plaintiffs' ability to control where, and under what law, their nonpatent claims will be heard. 
HeinOnline -- 92 Geo. L.J. 610 2003-2004 